\title{
BUILDING RESILIENCY INTO A RESOURCE-BASED COMMUNITY
}

\author{
by
}

JOHN VIEIRA

A thesis submitted to the Faculty of Graduate and Postdoctoral Affairs

in partial fulfillment of the requirements for the degree of:

\section{Master of Аrchitecture}

in

Azrieli School of

Architecture and Urbanism

Carleton University

Ottawa, Ontario

() 2021

John Vieira 


\section{ABSTRACT}

A significant number of isolated, resource-based communities аге scattered across Canada. The development of these communities revolves around a relationship between localized resource extraction and non-localized, market capital flows. Given the dynamic and unpredictable nature of the marketplace, the ability of such communities to grow and ргоsper is largely determined by external factors.

This thesis looks to recast and stabilize the economy of Nakusp, a community located in the interior of British Columbia, through the introduction of new programming and a phased community masterplan. The design proposal is influenced by the context of гuгal development within the province, successful programming precedents, and planning ргеcedents in other communities. A node and pathway relationship in the town establishes a network of interdependency among new and existing areas. This urban plan aims to build a level of resiliency into the community's future growth. 

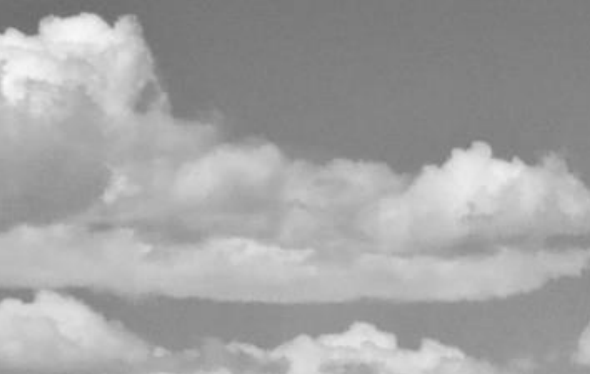

crangon

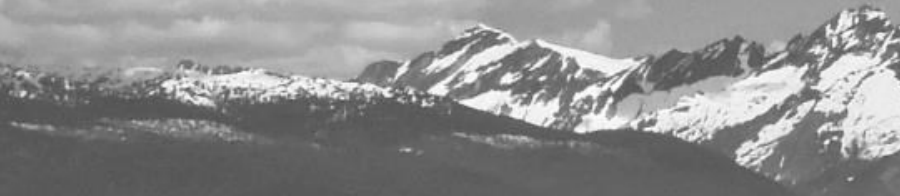
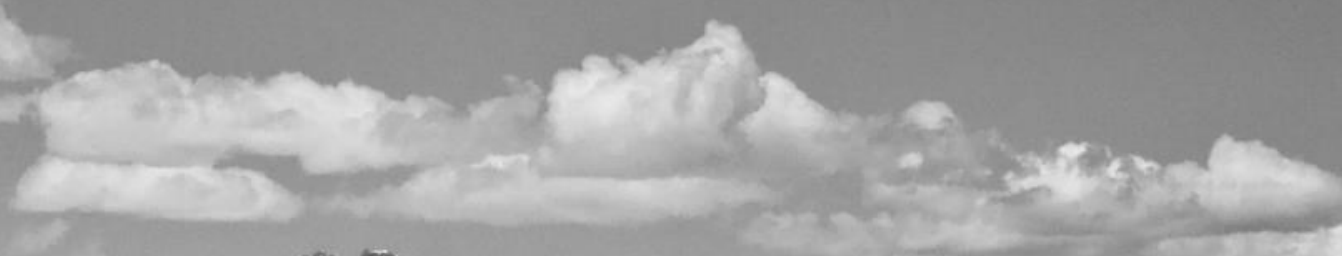


\section{ACKNOWLEDGEMENTS}

I would like to thank my supervisor Ben Gianni for his guidance, wisdom, and patience over the course of this research. I know my ideas ran wild, changed, and then changed again without notice. Thank you for words of encouragement throughout my project.

Thank you to Eden, Emma, and Emily for taking me in during my final months on this project. I cannot imagine this experience any different without all the shared meals and laughter on Elgin Street.

Thank you to the Watt family in Nakusp - for letting me into your home when I was just starting out and bouncing ideas around for this research.

Finally, thank you to all of my loving family - who have been an endless means of support from afar. Thank you for believing in me when I decided to pursue a career in design. 


\section{TABLE OF CONTENTS}

ABSTRACT

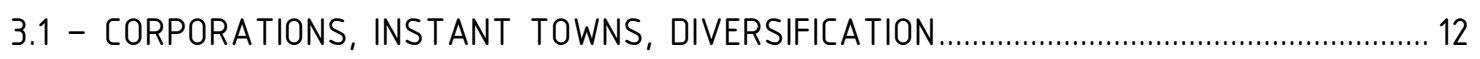

3.2 - COLUMBIA RIVER INFASTRUCTURAL INTERVENTIONS .................................................. 15

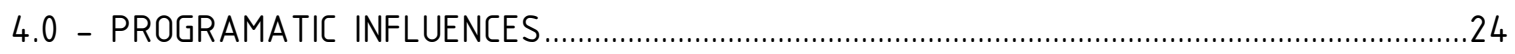

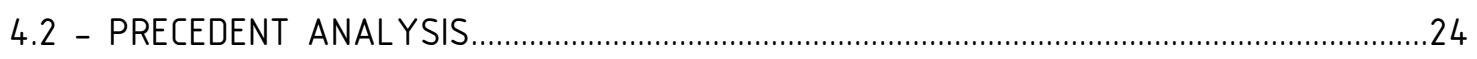

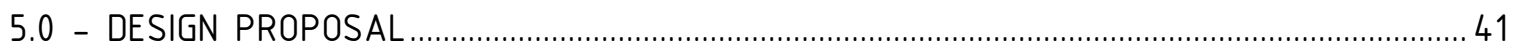

5.1 - PHASED URBAN PLAN

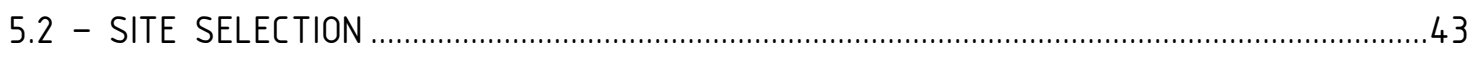

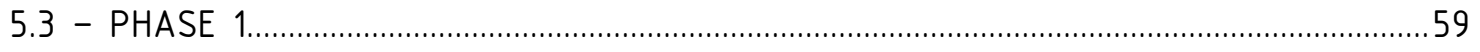

5.4 - PHASE 2

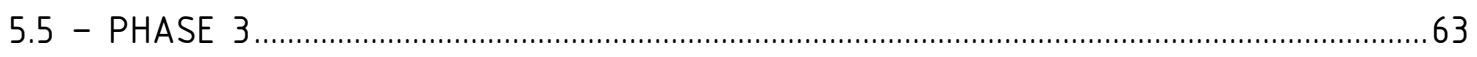

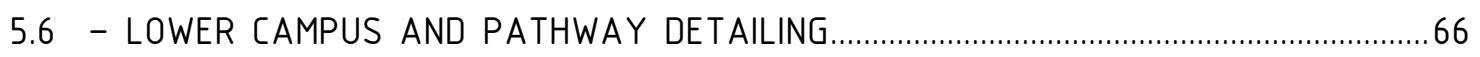

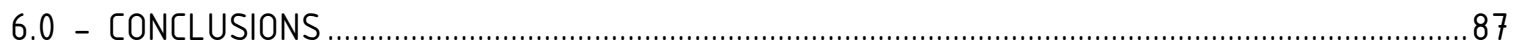

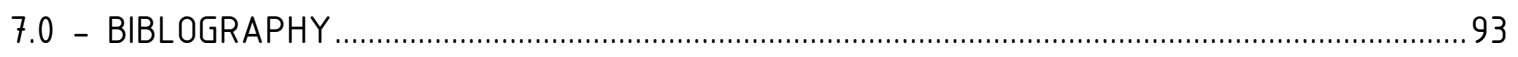




\section{LIST OF IMAGES AND ILLUSTRATIONS}

Fig. 1 - Nakusp 1:250 $000 \quad 4$

Fig. 2 - British Columbia Context 5

Fig. 3 - Nakusp Pole Train 7

Fig. 4 - Revelstoke Dam Under Construction 16

Fig. 5 - Мr. Schwartzenhauer Рrotesting 17

Fig. 6 - Church Агrival from Аггоw Park 18

Fig. 7 - Moving a House on Main Street prior to flood 19

Fig. 8 - Nakusp Waterfront - 196720

Fig. 9 - Nakusp Waterfront - 1968

Fig. 10 - Ргоgгаm Input-Output $\quad 24$

Fig. 11 - Ргоgгam Precedent - Art House Project 29

Fig. 12 - Ргоgгam Рrecedent - Fogo Island Inח 30

Fig. 13 - Ргоgгam Рrecedent - Cheakamus Centre 31

Fig. 14 - Рrogram Precedent - Quest University 32

Fig. 15 - Ргоgram Precedent - Wood Innovation Design Centre 33

Fig. 16 - Ргоgram Ргеcedent - Kwantlen Polytechnic University 34

Fig. 17 - Ргоgram Рrecedent - Banff Centre 35

Fig. 18 - Planning Precedent - Simon Fraser University 36

Fig. 19 - Planning Precedent - Seaside 37

Fig. 20 - Planning Precedent - University of British Columbia 38

Fig. 21 - Planning Precedent - Whistler 39

Fig. 22 - Town Inventory $\quad 44$

Fig. 23 - Town Inventory without Residential Buildings 45

Fig. 24 - Site Selection - Key Map 46 
Fig. 25 - Lakefront Aerial - 1981

Fig. 26 - Highway Bypass - $2000 \quad 48$

Fig. 27 - Site Aerial - 1981

Fig. 28 - Site Selection - Upрeг \& Lower Campus 51

Fig. 29 - Site Selection - Sawmill Lakefront 53

Fig. 30 - Site Selection - Industrial Sites 55

Fig. 31 - Site Selection - Downtown Waterfront 57

Fig. 32 - Town Urban Plan 58

Fig. 33 - Urban Plan - Phase 1

Fig. 34 - Urban Plan - Phase 2

Fig. 35 - Urban Plan - Phase $3 \quad 64$

Fig. 36 - Pathway Materiality 67

Fig. 37 - Proposal Detailing - Key Map 68

Fig. 38 - Vignette - End of Рier 69

Fig. 39 - Vignette - End of 6th Street 70

Fig. 40 - Section - Midtown 71

Fig. 41 - Vignette - Education Intersection 72

Fig. 42 - Vignette - Overpass 73

Fig. 43 - Lower Campus Masterplan 74

Fig. 44 - Lower Campus division plan 75

Fig. 45 - Detail Plan - Recreation Plaza 76

Fig. 46 - Detail Plan - End of Block 77

Fig. 47 - Detail Plan - Mid-Block 78

Fig. 48 - Section Perspective - Recreation Plaza 79

Fig. 49 - Section Perspective - End of Block 80

Fig. 50 - Section Perspective - Mid-Block 81 
Fig. 51 - Vignette - Towards Uррег Campus 82

Fig. 52 - Perspective - Campus Aerial 83

Fig. 53 - Perspective - Sawmill Lakefront Residential 84

Fig. 54 - Perspective - Overall Network 85

Fig. 55 - Site Selection - Alternate Campus Locations 91 


\section{0 - INTRODUCTION}

I've been long puzzled about the focus of architectural work on populated, urban environments. Моге often than not, design problems аге associated with cities, suggesting that a career of architecture could only exist in and focus on urban environments. It seemed out of synch with my past experiences with smaller communities in which many people lead fulfilling lives. I hoped to use this thesis to work through this internal dilemma, i.e., as a way of exploring how my design training might be brought to bear on is issues with which I've become familiar in гural contexts. Among these are the complex relationships between extractive industries and small communities.

Forestry and wood products production necessitates the management of large tracts of land. In British Columbia, the forestry industry has been largely consolidated into and dominated by a handful of large, multi-national companies. The presence of large coгрогаte interests on a sparsely populated region has implications on population distribution/conurbation, ecology, and land-use. While forestry companies will apply a triple-bottom line to the best of their ability, strategies are only as effective as companies remain healthy. History has proven that financial viability overcomes other considerations. Coгрогаte responsibility and community commitment is inextricably tied to согрогаte survival.

During my undergraduate studies in forestry, I had the privilege of working in a number of гuгal communities in British Columbia. This experience afforded me insight into the forestry industry, potential сагеег paths, and most importantly, the kinds of people a сагеег in forestry might attract. Forestry jobs abound in British Columbia, from small coastal towns to northern industrial cities.

Despite differences in size and location, these communities, largely developed around resource extraction sites. Put simply, an enterprise would enter a region and the workforce employed spawn a new ог expanded townsite. Communities such as these operate within a defined - and revenue-positive - relationship between primary extraction, refinement, and 
distribution of goods. While many communities have ргоspered within this system, their long-term viability is tied to variable market forces that аге largely beyond their control. Uncertainty about what the future might hold can prompt migration towards more dense and economically diverse urban centers. What is left in the wake of an enterprise closing or moving operations is legacy of dependencies on a missing company.

Understanding that the phenomenon I'm describing is a product of globalization, from which I have personally benefitted, I have seen small communities left behind. Several the communities with which I've interacted аге entirely dependent on a single enterprise. Global issues such as the number construction starts within the United States, clean energy policies in Europe, or demand for building materials in Asia can dictate trade negotiations on a scale of the nation-state, but seem abstract and ігrelevant to individuals who cannot find employment locally. Могеover, marginalized communities that have lost their economic base may bear the burden of adverse environmental legacies, for which no initial consultation or subsequent compensation was ever provided. ${ }^{2}$

This study is intended to help the Village of Nakusp sketch out a pathway to the future, to transition from existing economic structures and its sole reliance on resource extraction. It explores how design professionals might help communities like Nakusp to address the challenges they face. Included in the thesis is design proposal intended as a high-level roadmap for diversifying, expanding, and transforming the community. It includes accommodations for a new post-secondary institution, new residential and industrial zones, an expanded road network, and a multi-use pathway to link new and existing development. This plan - and the elements it incorporates - are intended to function as a catalyst for community engagement and provide Nakusp with a vision of what the community could become.

In addition to other research methods, this thesis employs a "research-by-design" ргосеss. This entails generating lагger themes, nаггоwing the themes into contextualized questions, building a knowledge base of historical ргоcesses and паггаtives, then ргоposing design 
iterations to arrive at a vision for the community's future. This vision, in turn, is intended to act as a starting point for further discussion.

${ }^{1}$ Chloe Brown, "The Geography of Climate Change in a Rural Resource-Dependent Town: The Case of McBride, British Columbia" (Simon Fraser University, 2012), http://summit.sfu.ca/item/12472.

${ }^{2}$ Mariko Gwendolyn Molander, "Decolonizing the Mind: Centring Settler-Colonial Disposession and Mutually Contested Sovereignties in British Columbia's Forestry Landscape and Narrative" (University of Вritish Columbia, 2014), https://doi.org/10.14288/1.0167634. 


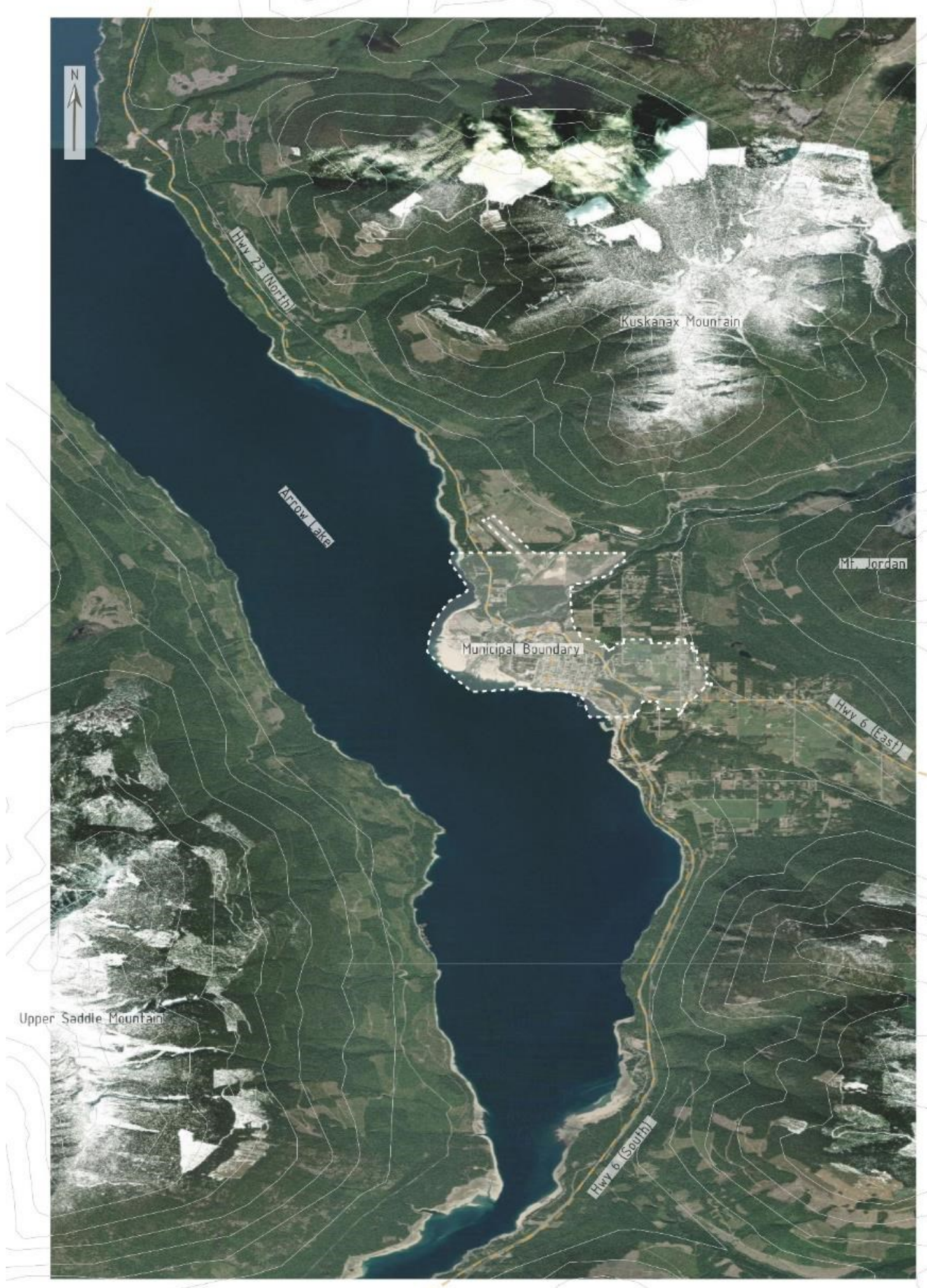

Fig. 1 - Nakusp 1:250 000 


\section{0 - NAKUSP}

This thesis addresses the issues identified above by proposing a master plan for the growth and transformation the community of Nakusp, which is located in the south-eastern portion of British Columbia, also known as the Kootenay region. For rough gauge of proximity, Nakusp is a 7-hour car ride from Metro Vancouver, the largest urban region in the province. It is approximately three and a half hours west of Kelowna (via Vernon), which is BC's third largest city, and the second largest outside of Metro Vancouver.

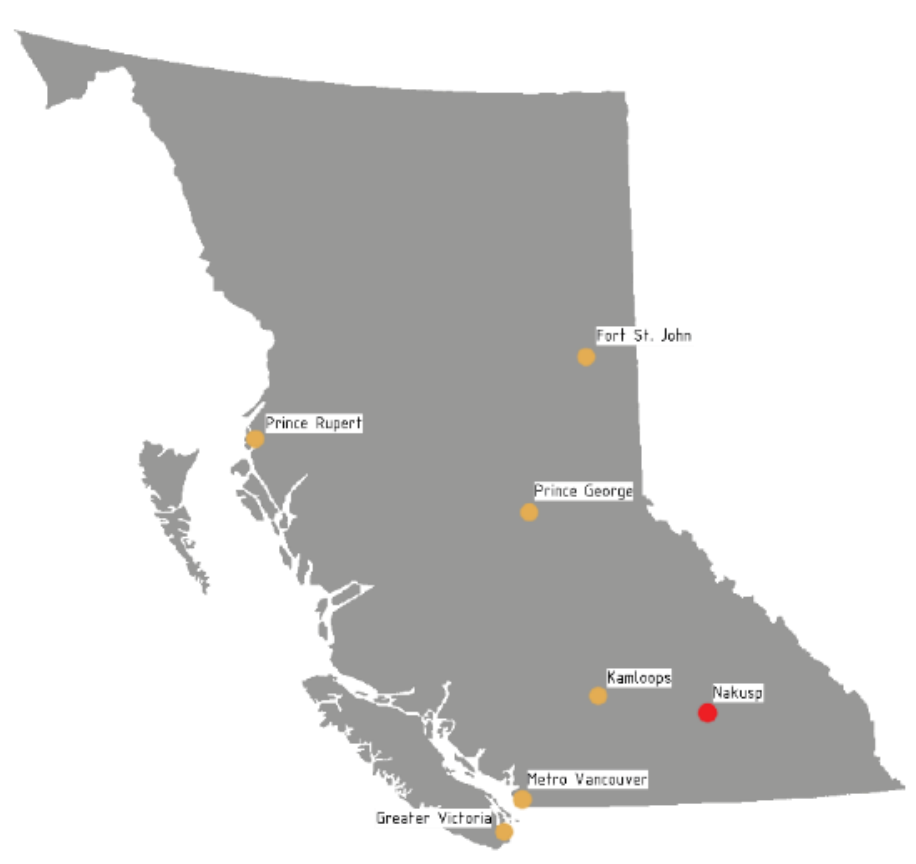

Fig. 2 - British Columbia Context
Nakusp is situated between two mountain ranges, the Monashee to the west and the Selkirk to the east (see fig. 1). It is located on еastern shore of АггоW Lake, which is fed by the Columbia River. The Columbia basin is spread over Canada and the United States, eventually draining into the Pacific Ocean near Astoria, Oregon.

The town's name derives

from the Sinixt first nation, attributed to the narrowing of Агrow Lake near the townsite. ${ }^{3}$ This narrowing, however, is no longer аррагеnt, due to significant alternations to the coastline as a result of a series of hydroelectric dams along the river. ${ }^{4}$

Nakusp was surveyed and registered in 1892, with the first post office having been established the ргеvious уеаг. The town's development was largely driven by industrial forestry and as a connection point to mining facilities in neighbouring communities. 
The Arrow Lakes Valley, which separates the Monashee and Selkirk ranges, is known for its numerous natural hot springs, some developed and others untouched, with the municipality currently owning and operating a hot springs facility. A unique revenue stream for the municipality comes from the Nakusp and Агеa Community Forest (NACFOR). This municipally owned entity holds resource tenure rights to portions of the surrounding forest. Local professionals аге contracted through NACFOR for harvesting services, profits from which eventually find their way into municipal revenue streams.

The municipality of Nakusp comprises 1130 residents according to the 2016 Canadian census. ${ }^{6}$ This number is slightly higher when including unincorporated rural communities within the Аггоw Lakes Valley, as Nakusp acts as a regional hub for commercial activity.

The town's situation on a broad lake with uninterгupted views to the surrounding mountains contributes to its unique appeal: a small village atmosphere, isolated from large population centres, with significant potential for outdoor гесгеation. The small size of the community, however, is the result of a historically fluctuating economy. 


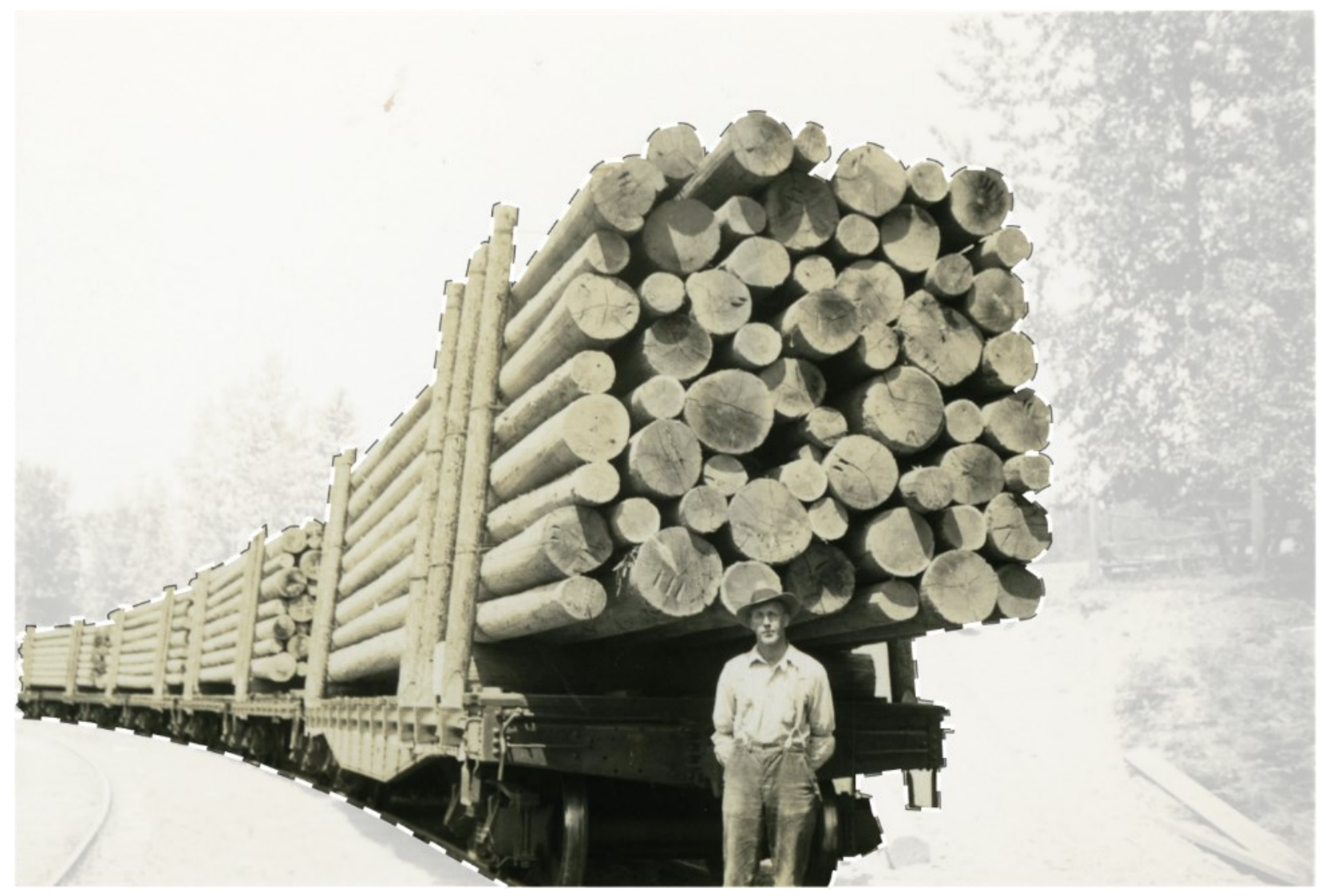

Man (Archie Herridge?) posing in front of train cars carrying log poles from Bell Pole Co. Canadian Pacific (Nakusp \& Slocan) Railway, Nakusp, ca. 1940s. - Arrow Lakes Historical Society

CREATOR: Estate of Hazel Fellows

IMAGE DATE: 1940-1949

SOURCE: https://alhs-archives.com/document/2017-034-33-poles-on-boxcars-nakusp/

Fig. 3 - Nakusp Pole Train 


\section{1 - HYPOTHESIS}

Similar to other гuгal communities, Nakusp follows a development model - both physical and economic - based on resource extraction. As long as resources flow out of the community, money flows in, and can be directed toward social infrastructure that benefits residents. A heavy dependence on a single industry, however, can be risky. ${ }^{7}$ Halseth and Sullivan show that many of the 'company towns' and 'resource-based towns' in British Columbia have their origins in a company's obligations to house workers. ${ }^{8}$ There even exists a contempoгагy tendency for сгеating temporaгy, 'fly-in' camps that exist only for the duration of an infrastructural project. ${ }^{9}$ Теmрогагу camps аге seen as a cost-effective solution when compared to comprehensive town planning, and are able to draw from a larger pool of labour sources. ${ }^{10}$

While not all enterprises involved with resource extraction will build tеmрогагу communities, this practice contributes to an impression that rural communities are not sustainable and that they exist largely to support people who live urban centres. Temporary workers travel to rural outposts to support what is ultimately an urban livelihood. The binary categorization between urban and гигаl агеas can be viewed as an extension of discourse between centre/регiphery classifications. The ruгal (регірhery) serves and is subservient to its "other," namely the urban (centre). In an age of exponential growth in global population, it seems unsustainable to direct all urban growth to established cities. One pathway to counter urban expansion would be to question why гигаl settings аге not favourable fог ргоfessional livelihoods.

The history of the towns like Nakusp is the history of forestry companies appearing, ргоspering, and dissolving. Following the 2008 recession, Nakusp residents staged a series of town halls. A key takeaway from one meeting was that the town's economy was "ruled by external forces beyond [its] control"."

While the 2008 recession did not spark a sudden realization of the municipality's dependency on a single industry, it was another in a series of reminders of the need for economic diversification. With such strong historical and economic ties to forestry, 
however, it can hard for lumber towns like Nakusp to chart new paths forward without feeling like they might be compromising their identity. And while attracting a single, 'dropin' industry would address the short-term need for jobs, the prospect of replacing one industry with another is risky. Among other things it would require job re-training and significant capital investment that could take years to pay off. A sounder, long-term strategy should include a diverse range of economic initiatives, which was another of the conclusions of the 2008 town halls. Indeed, Nakusp's сиггеnt marketing plans incorрогаtes a range of investment opportunities. ${ }^{12}$

\section{2 - PROJECT APPROACH}

The method guiding this thesis exploration might be best described as an historical analysis informing an iterative design ргоcess. The key questions guiding the investigation were as follows:

- How can a small, resource-based community transform into a resilient, sustainable community?

- How might a design proposal contribute to loosening the dependencies on existing, non-localized extractive industries that are subject to global capital markets?

- How might a post-secondary educational institution contribute not only to the town's economy, but to the examination of rural-urban dependencies in Canada?

- What post-extractive industries have helped to revitalize other, similar communities?

- What role might design play as a catalyst for community transformation?

Once formulated, these questions were applied to a specific case study, namely Nakusp. Pertinent as they аге to many resource-based communities, these questions are best explored through a specific example. An overview of historical events in the агеa, a review of municipal documentation, and an analysis of precedents in similar communities informed decisions about the components/ргograms to include. Generating an inventory of the current building stock in the village also informed decisions of locating ргоgrammatic elements. 
From that point forward, an iterative "research-by-design" process shaped the evolving ргоposal. Ргоgrammatic elements were mapped to different sites around Nakusp to exploге issues and fit. The following issues weге considered when evaluating what elements to include and where:

- Increasing Youth Retention in community. Enhancing the appeal of the town as a place to study, settle and work after graduation.

- Engagement of Elderly and other existing locals

- Providing new employment opportunities - for a range of skill levels.

- The inclusion of amenities to supplement existing public facilities and enhance the appeal of the town as a place to live - both for young families and retirees relocating from metropolitan centres. These include both cultural and гесгеational facilities.

- Supplementing existing tourism initiatives and increasing the visibility and ргоfile of Nakusp as a place to visit

- Connecting the town with waterfront to the west and south

- The relationships between what exists and what's proposed, such that new uses complement гather than compete with existing.

- Reinforcing and connecting all new uses to the existing town center.

- Alterations to the existing road network to address existing issues such as truck traffic though the center of town.

- Favoring pedestrian movement and the use of bicycles by providing key connections and multi-use paths. 
${ }^{3}$ Greg Nesteroff, "Nakusp from a Sinixt Word, but Meaning in Doubt," Arrow Lakes News, June 1, 2016, https://www.arrowlakesnews.com/news/nakusp-from-a-sinixt-word-but-meaning-in-doubt/.

4 BC GOV, "Columbia River Treaty," Columbia River Treaty, 1473168504,

https://engage.gov.bc.ca/columbiarivertreaty/.

${ }^{5}$ Nesteroff, "Nakusp from a Sinixt Word, but Meaning in Doubt."

${ }^{6}$ Statistics Canada Government of Canada, "Census Profile, 2016 Census - Nakusp, Village [Census Subdivision], British Columbia and British Columbia [Ргоvince]," February 8, 2017, https://www12.statcan.gc.ca/census-recensement/2016/dppd/prof/details/page_Figures.cfm?Lang=E\&Tab=1\&Geo1=CSD\&_ode1=5903050\&Geo2=PR\&Code2=59\&SearchText $=$ Nakusp\&SearchType=Begins $\&$ SearchPR $=01 \& B 1=A l l \& T A B I D=1 \&$ type $=0$.

${ }^{7}$ Greg Halseth and Lana Sullivan, "From Kitimat to Tumbler Ridge: A Crucial Lesson Not Learned in Resource-Town Planning," Western Geography 13/14 (n.d.): 132-60; John Вradbury, "Instant Towns in British Columbia: 1964 to 1972" (Simon Fraser University, 1977), https://summit.sfu.ca/item/2873.

${ }^{8}$ Greg Halseth, Lana Sullivan, and Laura Ryser, "Service Provision as Part of Resource Town Transition Planning:," n.d., 33.

9 Laura Ryser et al., "Moving from Mobility to Immobility in the Political Economy of Resource-Dependent Regions," Applied Mobilities 4, no. 3 (September 2, 2019): 307-28, https://doi.org/10.1080/23800127.2017.1421290.

${ }^{10}$ Halseth and Sullivan, "From Kitimat to Tumbler Ridge: A Crucial Lesson Not Learned in Resource-Town Planning."

${ }^{11}$ Village of Nakusp, "Economic_summit_final_report_november_2011.Pdf," accessed October 8, 2020, https://nakuspareadevelopment.files.wordpress.com/2016/11/economic_summit_final_report_november_2011.p df.

12 Investment Ready Nakusp, "Nakusp Is READY FOR INVESTMENT," Investment Ready Nakusp, accessed January 11, 2021, https://investmentreadynakusp.ca/. 


\section{$3.0-B A C K G R O U N D$}

\section{1 - CORPORATIONS, INSTANT TOWNS, DIVERSIFICATION}

John Вгadbury, a geographer based at Simon Fraser University, provides the background for the large-scale investment in resource development that occurred in Вritish Columbia between 1952 and 1972. Multi-national companies began to operate in гuгal areas асгоss the province during this period. The premier of the time, W.A.C. Bennett, promoted access to natural resources and created policies that encouraged large-scale investment:

"British Columbia was to fulfill her potential as a staples-producing hinterland not only for Canada but for the world at large. The world at large included the multinational согрогаtions in Europe, Japan and the United States, and government would facilitate the fulfillment of this potential by '...providing the ways and means that would attract and assist capital and labour to convert idle riches and power into products and instruments"13

This was part of a nation-wide push for resource companies to "build livable communities to attract and hold their labour force" in rural areas. ${ }^{14}$ In British Columbia, this was manifested through the construction of large amounts of transportation infrastructure, massive hydroelectric projects, changes to forest resource tenuгe policies, and the creation of instant communities. ${ }^{15}$ A focus towards Fordist, mass-production-scale facilities and access to seemingly endless natural resources allowed for the rapid generation of industries. In combination with large private enterprises, ргovincial crown согрогаtions were set up to enable a province-building agenda. ${ }^{16}$

Instant towns - quickly planned municipalities paired with industrial sites - were an initiative of the provincial government. Creating planned, instant towns around resource sites was ргеferable to the chaotic, boom-and-bust communities that appeared prior to the Second World War. ${ }^{17}$ While ad hoc 'shack-towns' were the sole responsibility of the employer, this new generation of towns would be mоге огderly, employing land-use-based planning. Properly planned, an instant town could attain municipal status soon after it 
was constructed, enabling residents to collect taxes and exercise further control over infrastructure and land use. ${ }^{18}$

In communities such as Tumbler Ridge, Mackenzie, and Kitimat, residential агеas wеге separated from the industrial zones where residents worked. The spatial logic of separating and isolating differing land uses -- based on garden city precedents and Radburn principles - was beneficial to communities across British Columbia. ${ }^{19}$ "A comprehensively planned community should provide as many of the services and amenities which households and families will need in order to feel 'at home'"20 These principles gave residents a sense of permanency and certainty while enabling enterprises to profit from un-tapped potential.

Вгаdbury агgues that the арреагаnce of large-scale enterprises, paired with the creation of instant towns, entrenched dependencies on resource extraction throughout the province. Communities were established with the assumption that industry would withstand the vicissitudes of the commodities marketplace, despite the fact that they were still following the same dependency models of pre-WWII company towns. ${ }^{21}$ As early as 1975, drops in the demand for resources led to the stagnation of economies in many of these instant towns. ${ }^{22}$ Halseth and Sullivan point out that the resiliency of the towns created in this ега, i.e., their ability to negotiate global market trends, is still dictated by the financial success of the largest employer in each town. ${ }^{23}$ This means "a sense of increased vulneгability to not only global export markets but also the demands of stock market investors [in the company] for good quarterly ргofit results." ${ }^{24}$ In Northern British Columbia, Mackenzie and Tumbler Ridge both suffered as forestry and coal companies struggled to remain profitable. Halseth and Sullivan point out a missing component not found in Mackenzie and Tumbler Ridge:

"To survive, the company must obtain a successful mill, the workers a satisfied community, and the community must achieve some diversity as protection against economic boom and bust cycles, and the often cloaked but ever pervasive threats of town closure." ${ }^{25}$ 
While building and maintaining a network of social dependencies within the community can mitigate the impact of external market trends, social infrastructure will only last as long as residents remain in the community. ${ }^{26}$

"Without a driving need for diversification, foreign-controlled firms are often content to continue exporting basic resource commodities that are needed in their home economies or for other components of their multinational holdings. The resource hinterland remains just that, a resource hinterland with little additional economic diversification. ${ }^{27}$

These connections between resource towns and global metropolitan centres still exist today. Canadian forestry is largely dictated by activity in the United States; a drop in housing starts following the 2008 recession resulted in a significant reduction in the volume of lumber produced in British Columbia. ${ }^{28}$ Across British Columbia, the forestry industry is still extremely vulnerable to financial recessions in and beyond the province, affecting thousands of jobs, as was the case following the 2008 recession. ${ }^{29}$ People employed in resource extraction, manufacturing, and supportive tertiary industries rely on stable demand to maintain their livelihoods.

While Nakusp predates the instant towns described above, it is subject to many of the same forces. The town's history is inextricably tied to resource-extraction companies working within the public land-tenure framework. Nakusp's municipal government is well аware of the constraints under which it operates. During the 2011 town hall summits, the local chamber of commerce and Regional Development Board observed that:

"[b]oth organizations have ге-discovered the limitations of being very small and without the financial resources for paid staff. Lack of resources is a key organizational challenge for small communities and rural areas. We recognize that we must collaborate, pool resources, and avoid duplicating both effort and expense." ${ }^{130}$ 


\section{2 - COLUMBIA RIVER INFASTRUCTURAL INTERVENTIONS}

The creation and signing of the 1964 Columbia River Treaty between the United States and Canada had a significant impact in the Аггоw Lakes region. Canada and the United States both saw an increase in industrial production capacities following the Second World War. ${ }^{31}$ The demand for electricity and flood control within the Columbia River Basin led to the construction of large hydroelectric projects along the river. The Hugh Keenleyside Dam, downriver of Nakusp, was constructed at the same time as W.A.C Bennet Dam on the Peace River to the north. Canada's ratification of the Treaty marked an ега of provincial technological development - making a surplus of electricity available to metropolitan агеas throughout the province. ${ }^{32}$

Hydroelectric projects along the Columbia River raised the water level, submerging significant portions of the abutting land. Established communities in the Аггоw Lakes Valley disappeared and numerous buildings were relocated to higher ground in the years leading up to the flooding. Lakefront properties were flattened and compacted to stabilize the shoreline.

"BC регmanently flooded a total of 110,000 hectares, resulting in the loss of 3200 hectares of fertile agricultural land and 42,000 hectares of forest in the Kootenays, as well as displacement of a dozen small communities in which about 2,000 people lost their homes, primarily in the Агrow Lakes and Koocanusa reservoir regions - a somewhat ironic outcome given that this was done for the purpose of protecting US communities downstream from flooding." 33 


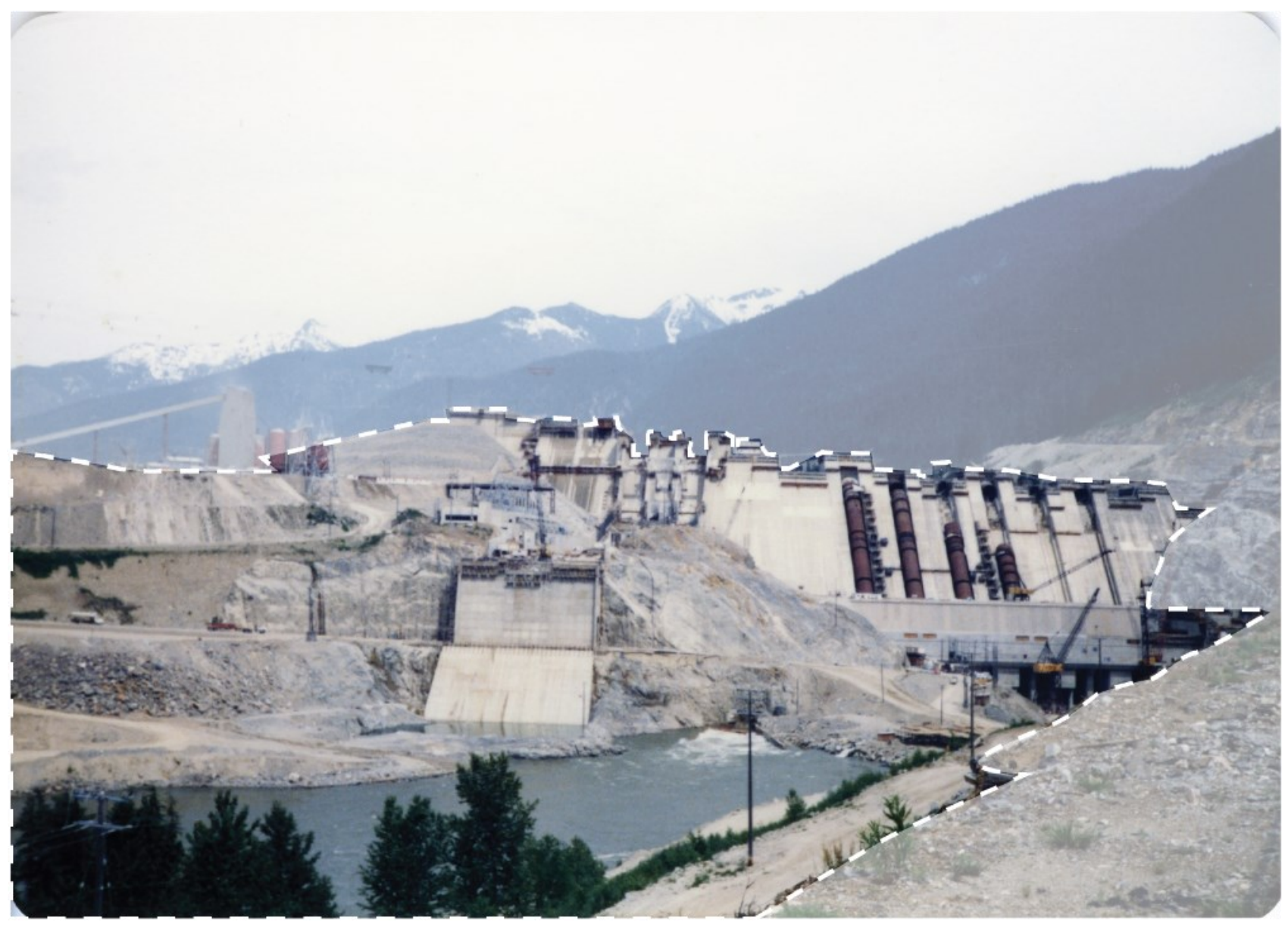

Revelstoke Dam under construction, Columbia River north of Revelstoke, June 1983. - Arrow Lakes Historical Society

CREATOR: Judy Adams

IMAGE DATE: 1983-06-

SOURCE: https://alhs-archives.com/document/2015-012-446-revelstoke-dam-under-construction-june-1983/

Fig. 4 - Revelstoke Dam Under Construction 


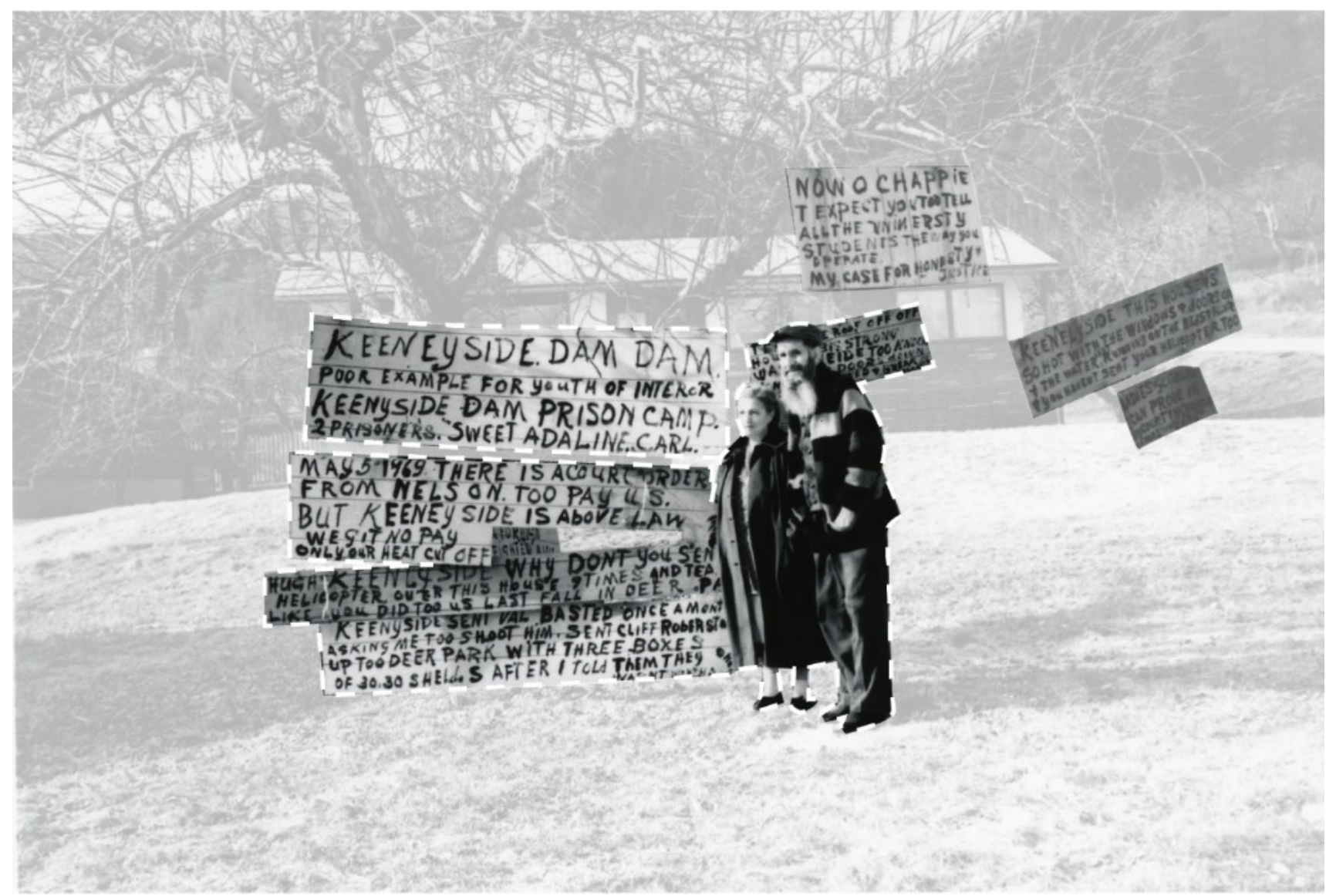

Carl Schwartzenhauer and his housekeeper Adeline Alderman posing with homemade signs in front of their new home in a subdivision in Robson constructed by BC Hydro as they protest the loss of their property at Deer Park to make way for the rising waters on Lower Arrow Lake that will be created by Hugh Keenleyside Dam, ca. May 1969. - Arrow Lakes Historical Society

CREATOR: Ellis Anderson

IMAGE DATE: 1969-05- 


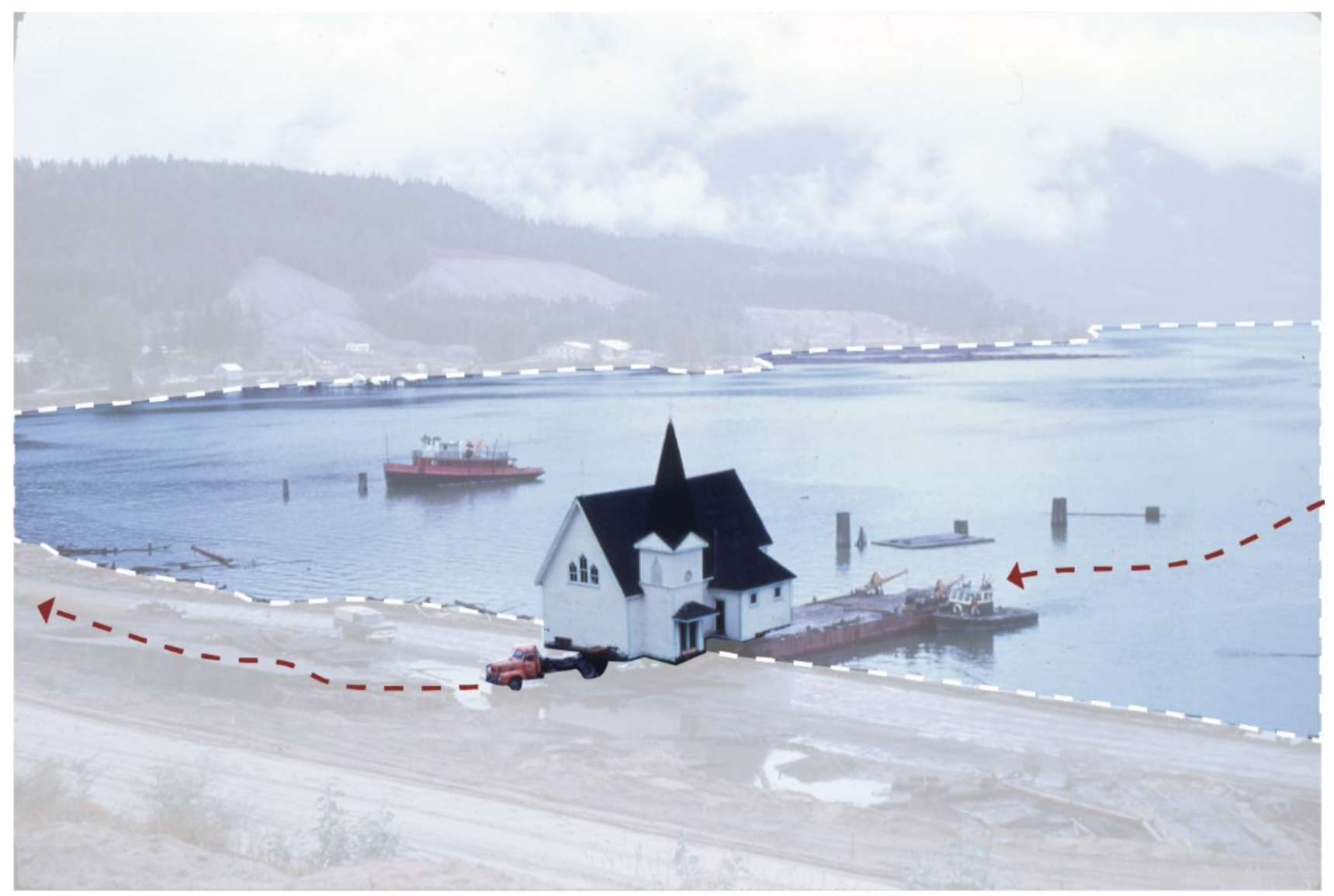

St. John the Divine Anglican Church arriving at Nakusp waterfront after being carried by barge from East Arrow Park, July 1967. The church would be relocated to 205 Grahame Street to serve as the new St. Mark's Anglican Church. - Arrow Lakes Historical Society

CREATOR: Florence Adshead

IMAGE DATE: 1967-07-

SOURCE: https://alhs-archives.com/document/2014-003-2120-anglican-church-arrival-at-nak/

Fig. 6 - Church Arrival from Arrow Park 


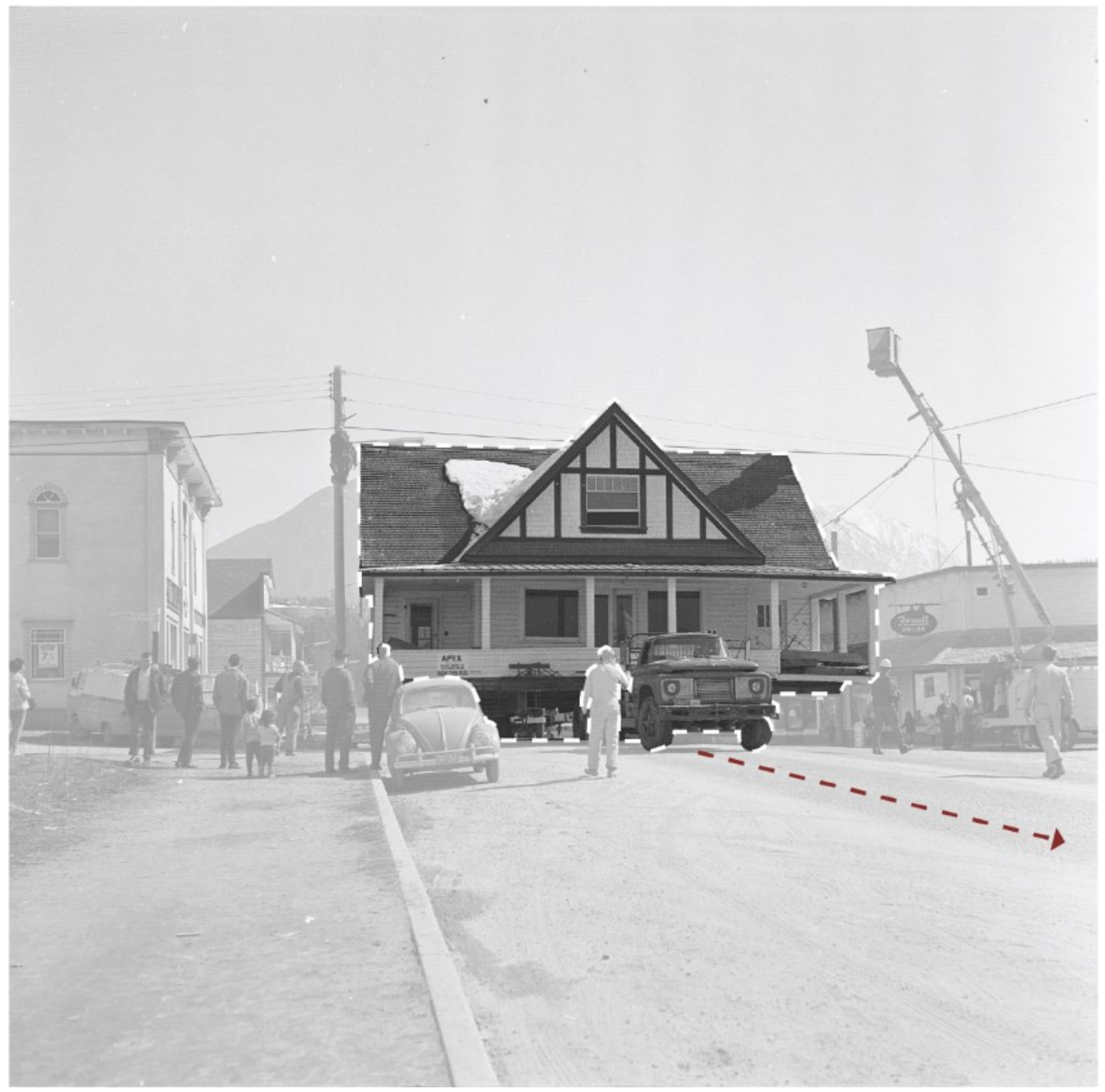

Ron Jordan house (originally Lewis Edwards housel being carried on flatbed down Broadway Street at Slocan Avenue during relocation of house from Rothwell Bay to current location (now 1007 4th Street NW), in advance of Arrow Lakes flooding. April 1969. - Arrow Lakes

Historical Society

CREATOR: Denis Stanley

IMAGE DATE: $1969-04-$

SOURCE: https://alhs-archives.com/document/2014-018-463-moving-edwards-house-1969/ 


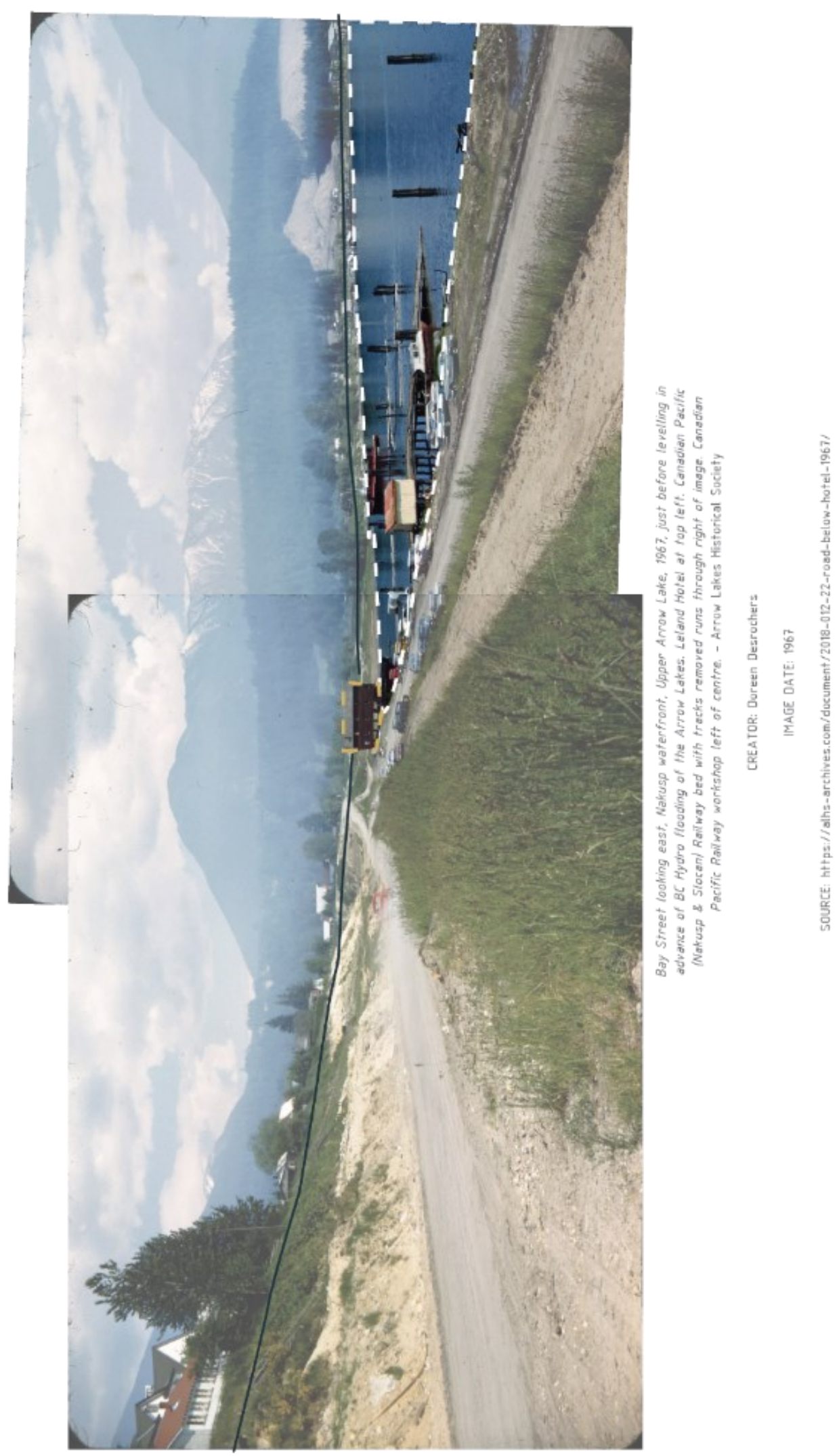

Fig. 8 - Nakusp Waterfront - 1967 


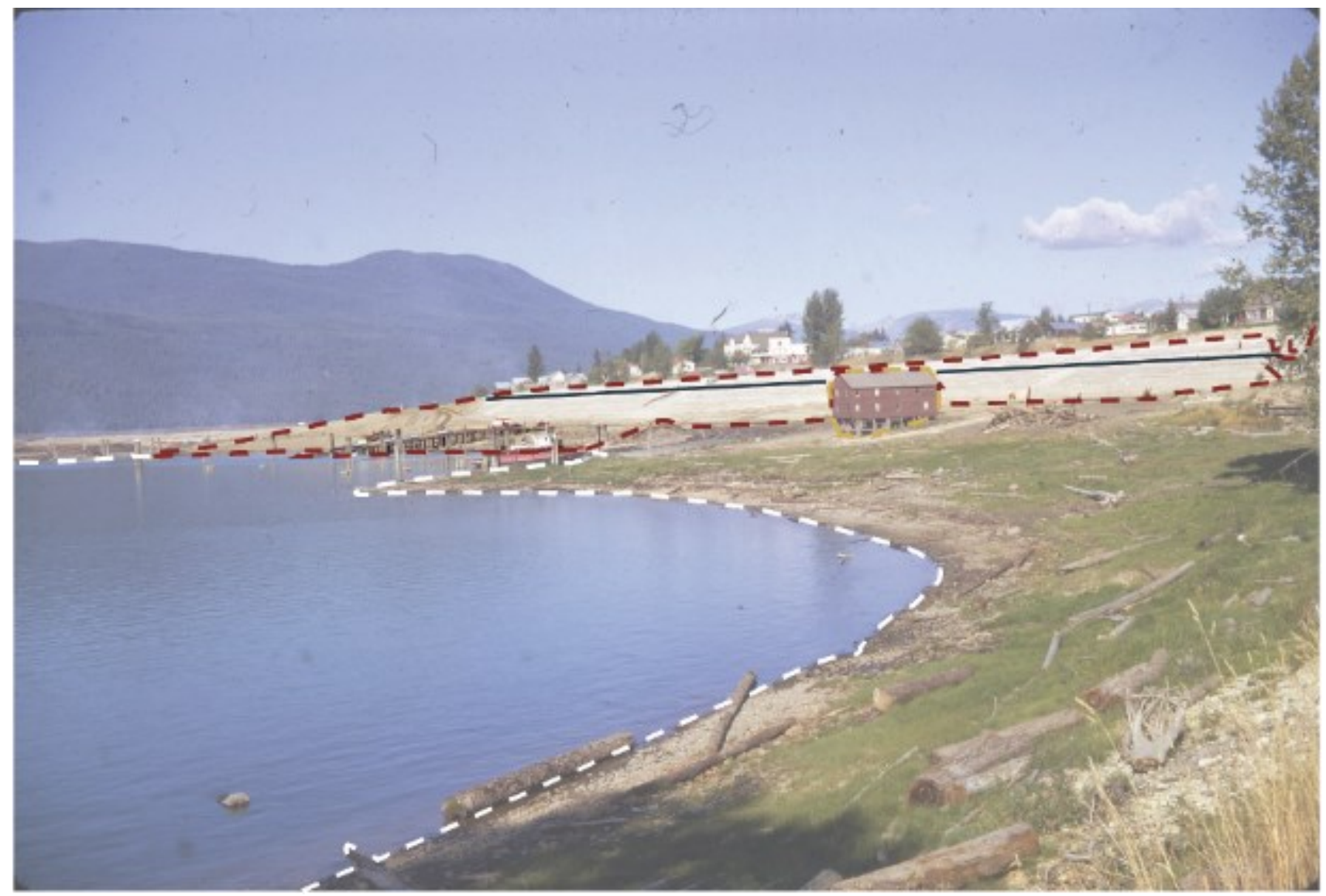

Govemment wharf and Canadian Pacific Rawway warkshop on Upper Amow Lake af Wakusp, 1958, affer the beachfront has been feveiled in adrance of ac Hydro's fiocding of the Arrow Lakes valley. = Arrow Lakes Historical Soricty

CREATOR: Dorken Despochers

IMAGE DATE: $\$ 968$

SOUACE: https//alhs-archives com/document/2018-012-25-before-water-rose-up-1960/

Fig. 9 - Nakusp Waterfront - 1968 
The signing of the treaty also diminished the presence of Indigenous people in the region, whose traditional tеггitory was already split between Canada and the United States:

"In that flood, 10,000 years of aboriginal culture was lost. The Sinixt Nation was declared extinct as an entity under the Indian Act. Many sacred sites such as burial grounds remain inundated by the Treaty's геservoirs, a fact that continues to aggravate old wounds as water levels rise and fall, periodically re-exposing the ancient sites, many of which have been looted and despoiled as a result." ${ }^{34}$

At ргеsent, the continual adjustment of water levels in the Keenleyside Dam геservoir can cause water level changes of up to 12 meters in the Аггоw Lakes ${ }^{35}$ - the difference between the white dashed line and solid blue line shown in Figure 9. Canadian residents resent their neighbors downriver in the United States inasmuch as hydroelectric power and flood control have contributed to "soil erosion, dust storms, an increase in rainfall and winter fog, floating debris, ргoliferation of insects, disturbances to birds and other wildlife populations and diminished presence of fish". ${ }^{36}$

The treaty privileged post-war engineering efforts over the long-term environmental and social wellbeing of people in the Аггоw Lakes region. In the 1990s, locals from the Canadian portion of the гіver basin negotiated with the ргovincial government to геceive a share of revenues stemming from the гiver treaty as герагаtions for the negative effects. In 1995, the Columbia Basin Trust was negotiated, providing funding for ргоjects throughout the river basin. ${ }^{37}$ 
${ }^{13}$ Вгаdbury, "Instant Towns in British Columbia: 1964 to 1972," 103.

${ }^{14}$ Halseth and Sullivan, "From Kitimat to Tumbler Ridge: A Crucial Lesson Not Learned in Resource-Town Planning," 135.

15 Halseth and Sullivan, 140.

${ }^{16}$ Вгаdbury, "Instant Towns in British Columbia: 1964 to 1972," 121.

${ }^{17}$ Halseth and Sullivan, "From Kitimat to Tumbler Ridge: A Crucial Lesson Not Learned in Resource-Town Planning," 133.

${ }^{18}$ BC GOV, "From Company to 'Instant' Towns: Building Resilient Local Government in B.C.'s Resource Communities," n.d., 2, https://www2.gov.bc.ca/assets/gov/british-columbians-our-governments/localgovernments/governance-

powers/from_company_instant_towns_building_resilient_local_government_in_bc_resource_communities.pdf ?bcgovtm=buffer.

19 Norman E. P. Pressman and Kathleen Lauder, "Resource Towns as New Towns," Urban History Review, no. 1-78 (1978): 91, https://doi.org/10.7202/1019441ar.

${ }^{20}$ Halseth and Sullivan, "From Kitimat to Tumbler Ridge: A Crucial Lesson Not Learned in Resource-Town Planning," 149.

${ }^{21}$ Bradbury, "Instant Towns in British Columbia: 1964 to 1972," 4.

22 BC GOV, "From Company to 'Instant' Towns: Building Resilient Local Government in B.C.'s Resource Communities," 2.

${ }^{23}$ Halseth and Sullivan, "From Kitimat to Tumbler Ridge: A Crucial Lesson Not Learned in Resource-Town Planning," 140.

${ }^{24}$ Halseth and Sullivan, 153.

${ }^{25}$ Halseth and Sullivan, 150.

${ }^{26}$ Halseth and Sullivan, 144.

${ }^{27}$ Halseth and Sullivan, 153.

${ }^{28}$ Statistics Canada Government of Canada, "The Great U.S. Recession and Canadian Forest Products," July 10, 2013, https://www150.statcan.gc.ca/n1/pub/11-626-x/11-626-x2013028-eng.htm.

${ }^{29}$ Dirk Meissner, "Worse than 2008? B.C. Forest Industry Facing Unprecedented Struggle," CTVNews, January 19, 2020, https://www.ctvnews.ca/business/worse-than-2008-b-c-forest-industry-facingunprecedented-struggle-1.4774063.

30 Village of Nakusp, "Economic_summit_final_report_november_2011.Pdf," 15.

${ }^{31}$ Robert William Sandford, Deborah Harford, and Jon O'Riordan, The Columbia River Treaty: A Primer (Victoria, CANADA: RMB Rocky Mountain Books, 2014), 11, http://ebookcentral.proquest.com/lib/oculcarletonebooks/detail.action?docID=5107146.

32 Sandford, Harford, and O'Riordan, 15.

33 Sandford, Harford, and O'Riordan, 20.

34 Sandford, Harford, and O'Riordan, 22.

${ }^{35}$ Sandford, Harford, and O'Riordan, 21.

${ }^{36}$ Sandford, Нarford, and O'Riordan, 21.

${ }^{37}$ Columbia Basin Trust, "Our Story," Columbia Basin Trust, accessed March 24, 2021, https://ourtrust.org/about/our-story/. 


\section{0 - PROGRAMATIC INFLUENCES}

This design exploration began with a consideration of the programmatic elements that might contribute to the economic and social stability of the town of Nakusp. A diagram (see fig. 10) describing the inflows and outflows of each ргоgramming assisted the process of determining appropriate ргоgramming.
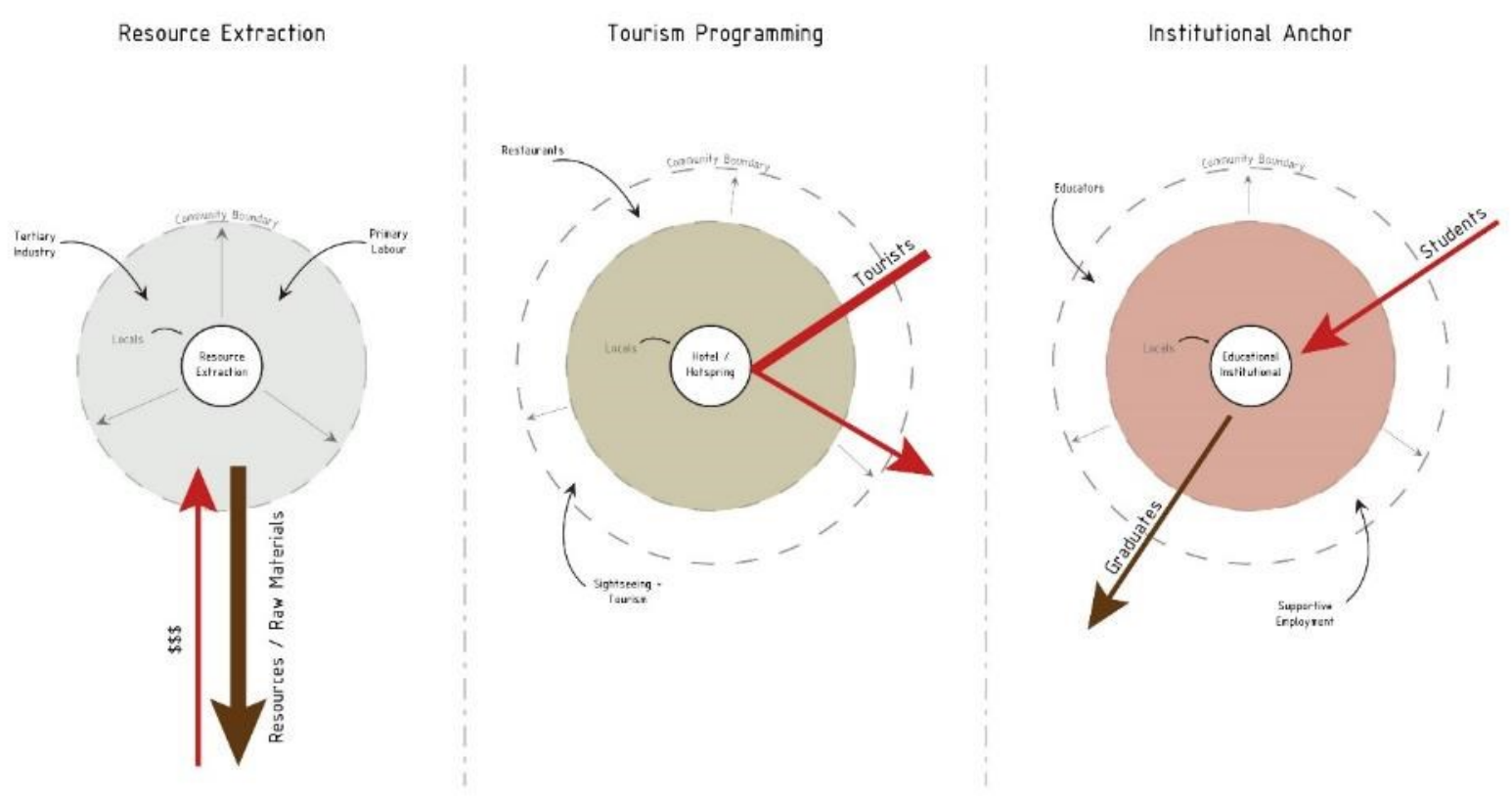

Fig. 10 - Ргоgгаm Input-Output

\section{TOURISM}

Given its scenic setting, the nearby hot springs, its appealing small-town atmosphere, and its proximity to established highway routes, Nakusp is a burgeoning hub for tourism. As such, tourist infrastructure is important to consider. ${ }^{38}$ Like other industries, however, tourism is vulnerable to larger forces such as global financial cycles and to health restrictions like those imposed during the 2019 Novel Coronavirus pandemic. Too nаггоw a focus on tourism will increase the town's exposure to an elastic market. ${ }^{39}$ 
Communities close to Nakusp have been hesitant to accommodate large, resort-style programming. The Jumbo Glacier Resort, a high elevation ski resort proposed for a municipality $90 \mathrm{~km}$ to the east of Nakusp, $4^{40}$ was delayed for 27 years by opposition from community groups, the development. In January 2020 the project was dropped. ${ }^{41}$ While other ski resorts within British Columbia enjoy the support of surrounding communities, ргoposals similar in scale to Jumbo will likely incite proportionally sized opposition. An exclusion of a resort-type zoning from the 2019 Nakusp bylaws is a strong indication of antipathy toward development schemes of this nature. ${ }^{42}$

\section{POST SECONDARY EDUCATION}

A post-secondary educational institution would contribute to the vitality and economic stability of Nakusp. While numerous residents work in jobs requiring higher education and/or training, there are few local facilities to provide it..$^{43}$ Nakusp residents who wish to attend college ог university, ог геquire continuing education, must commute or геlocate to neighbouring communities. Among other things, the presence of a post-secondary institution in Nakusp could inspire a future labour force to continue their education beyond high school. ${ }^{4}$

A post-secondary institution that provides vocational training could attract a new demographic to Nakusp, i.e., staff as long-term residents and an annual complement of students. Facilities that serve the educational institution could double as amenities for the community, supplementing and bolstering existing recreational and cultural infrastructure. Interdisciplinary curricula within the institution could map to community needs, matching programs that draw students from elsewhere to the growing need for trained labour British Columbia. ${ }^{45}$

Given the potential for an institution to compromise the village atmosphere valued by locals, however, where and how such an institution is situated аге important considerations. And while the viability of post-secondary institutions could also be affected by increased demand for remote learning -- as we've experienced during the 2019 Novel Coronavirus - trades cannot be taught online and hands-on learning is best done in person. 


\section{VALUE-ADDED MANUFACTURING}

An ongoing discussion in the Canadian forestry industry is the increased importance of "value-added" products. In a report first published in 2010, the Forest Products Association of Canada identified numerous emerging sub-sectors within the forestry industry. ${ }^{46}$ It observed that forestry resources, if continually managed in a sustainable and environmentally conscience manner, can provide a range of consumer products beyond standard dimensional lumber. These include sources of energy, textile products, and biologically derived plastics, in addition to solid wood materials, paper, and pulp. ${ }^{47}$ Valueadded manufacturing in forestry also includes the production of mass-timber products, such as cross-laminated timber. These match well with the larger need to mitigate the effects of embodied energy and C02 when choosing building materials, and the lагger effects of building design and construction on the earth's climate. ${ }^{48}$

The government of British Columbia is well aware of the role that forestry might play in the building industry. A 2009 provincial legislation named the Wood First Act requires that any provincially funded project be built primarily with wooden materials. ${ }^{49}$ While this act mandates that certain buildings be constructed with wood, an explicit intention of the act is to promote the construction of buildings with locally generated materials. As with other extractive industries, making the case that wood is more sustainable than other construction materials will depend on how well natural resources аге managed. The Wood First Act, in combination with ongoing efforts to promote suitable practices, positions value-added wood manufacturing in a positive perspective. Given the longstanding relationship between the forestry industry and the community, Nakusp could benefit from a value-added manufacturing facility.

\section{PROGRAMMING INTEGRATION}

Having identified a diverse set of initiatives around which the community might chart a path forward, it's important to address the physical expansion of the town. If thoughtful consideration is not given to the challenge of accommodating growth, an influx of 
institutions, industries and residents could put excessive demands on housing and lead to unanticipated and unwelcome changes to the community's character. ${ }^{50}$

As seen in the 2021 Nakusp Official community plan, single family homes make up $70 \%$ of the housing stock within the village. ${ }^{51}$ High energy costs associated with single family homes, an aging local population, and lack of housing stock suited to smaller households аге key points noted in the 2021 OCP..$^{52}$ Largely limited to single-family homes, low-income еагnегs аге forced to spend a higher ргорortion of their income on housing than if other housing options were available. ${ }^{53}$ It is important that new residential areas be used to address these issues.

The 2021 OCP also notes a lack of suitable industrial land within the village boundarу..$^{54}$ Established enterргises in the community already control most of the land designated for industrial uses. As such a new, value-added manufacturing centre will be require a new industrial park - in which other, similar uses could be grouped away from the existing townsite. These new industrial lands should not only meet the immediate needs of burgeoning enterprises, but also allow room for future growth.

Another consideration when determining ргоgramming for the community aге seasonal changes. It is helpful to consider how the different ргоgrams operate over the course of a given уеаг. Most educational institutions operate at a greater capacity from the fall to the spring of each уеаг. As students complete their studies tourism season kicks in. As such, new educational institutions could be designed to shift focus during tourism season. Post-secondary students studying in Nakusp could also find work during the summer break.

\section{2 - PRECEDENT ANALYSIS}

An investigation of precedents, i.e., a study of how of similar communities have dealt with similar challenges, will help to assess how best to approach the issues facing Nakusp. As noted above, there is no one solution, nог should Nakusp rely on a single, 'drop-in' 
intervention to offset the vicissitudes of the lumber industry. It must be a hybrid solution -- a multi-faceted approach to resiliency.

When considering ргоgram precedents, I was interested in the degree to which 1) the intervention occurred in a гuгal community, whose economy was based in resource extraction, 2) there had been a disengagement of industry from community members, leading to, 3) a drop in employment opportunities and, 4) and declining youth retention ргіог to the intervention. The precedents chosen range in scale from individual buildings to large-scale post-secondary institutions. Investigating case studies at a variety of scales enabled me to identify a bгоader range of strategies, understanding that all strategies would need to be adapted to the scale of Nakusp, i.e., be appropriate for a small, rural community. 


\section{ART HOUSE PROJECT} Naoshima, Kagawa Prefecture

Located in Japan's Seto Inland Sea, Naoshima hosts a number of art and architecture projects. Heavy manufacturing facilities are located on the northern end of the island. Art galleries, started by the Benesse corporation, were a means to attract tourists to the relatively quiet island. The Art House project consists of installations built from abandoned houses. Visitors purchase their admission tickets at the community hub, and wander through the Honmura neighbourhood to find the installations. The island has become a tourist destination for local day trips and international travellers. This was an applicable ргеcendent to the project as tourism initiatives supplemented existing industrial economies.
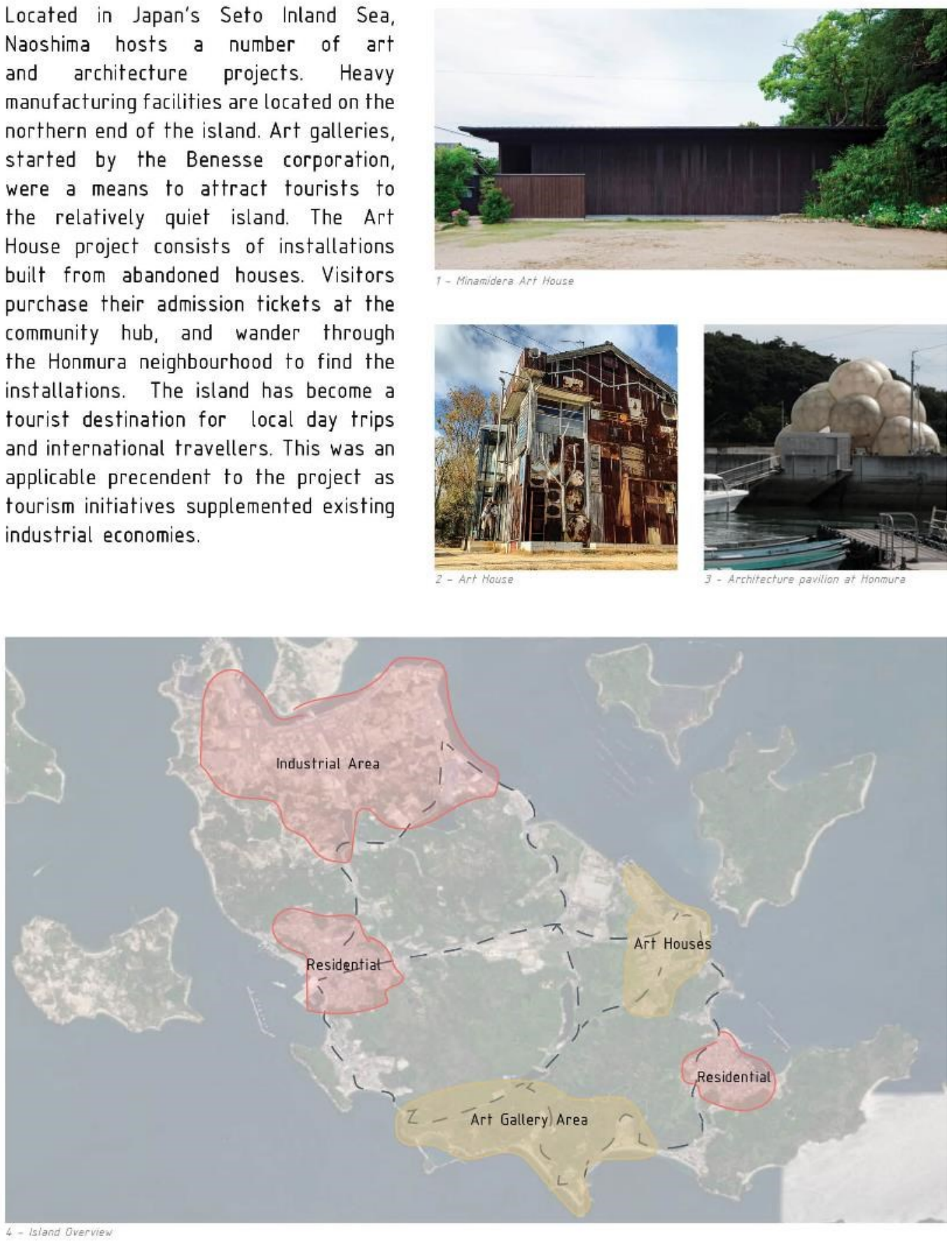

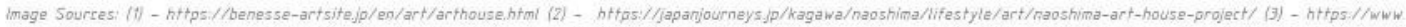
archdaily com/879282/cloud-shaped-pavilion-is-sanaas-latest-work-in-naushima/59ca6305b22e38667300005e-cioud-shaped-pavilion-is-sanaas-latest-work-in-nacshima-photo (4) - Edited ARCGIS Basemap

Fig. 11 - Program Precedent - Art House Project 


\section{PROGRAM PRECEDENT}

Prior to the hotel's construction, the economy of the region was heavily based in fishing. With depleting fish stocks, the economy of Fogo Island slumped. The hotel was envisioned as an engagement point for locals to rally around. As a tourist destination, visitors experience a rural setting from the comfort of a luxury hotel. Components of the Inn are furnished with locally manufactured products - from the rocking chairs to the bed duvets. In this case study, the tourism model is heavily dependent on the engagement of local artisans. This precedent showcases how small communities can embrace a tourism sector which draws on a large market.

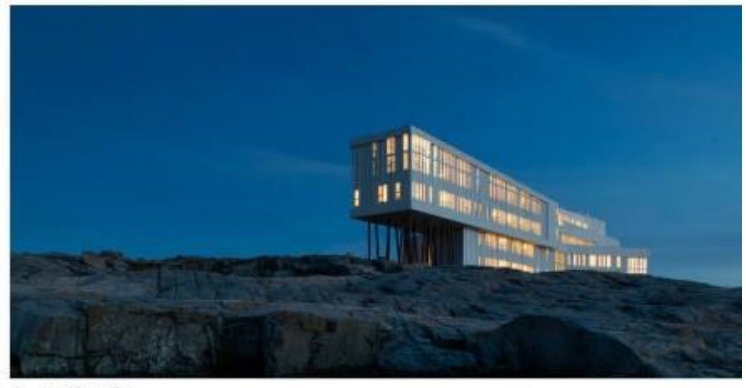

- inn Dverviei
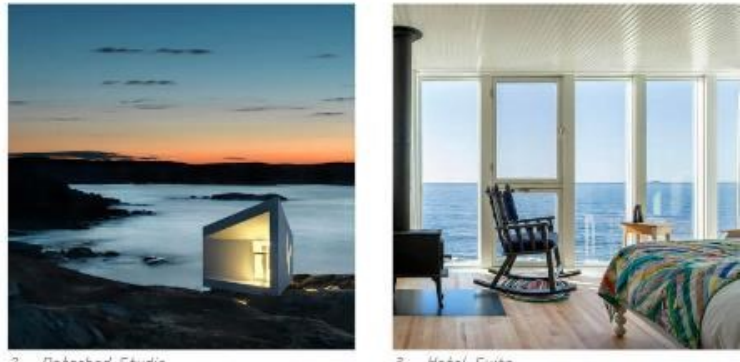

3. Hotel Suite

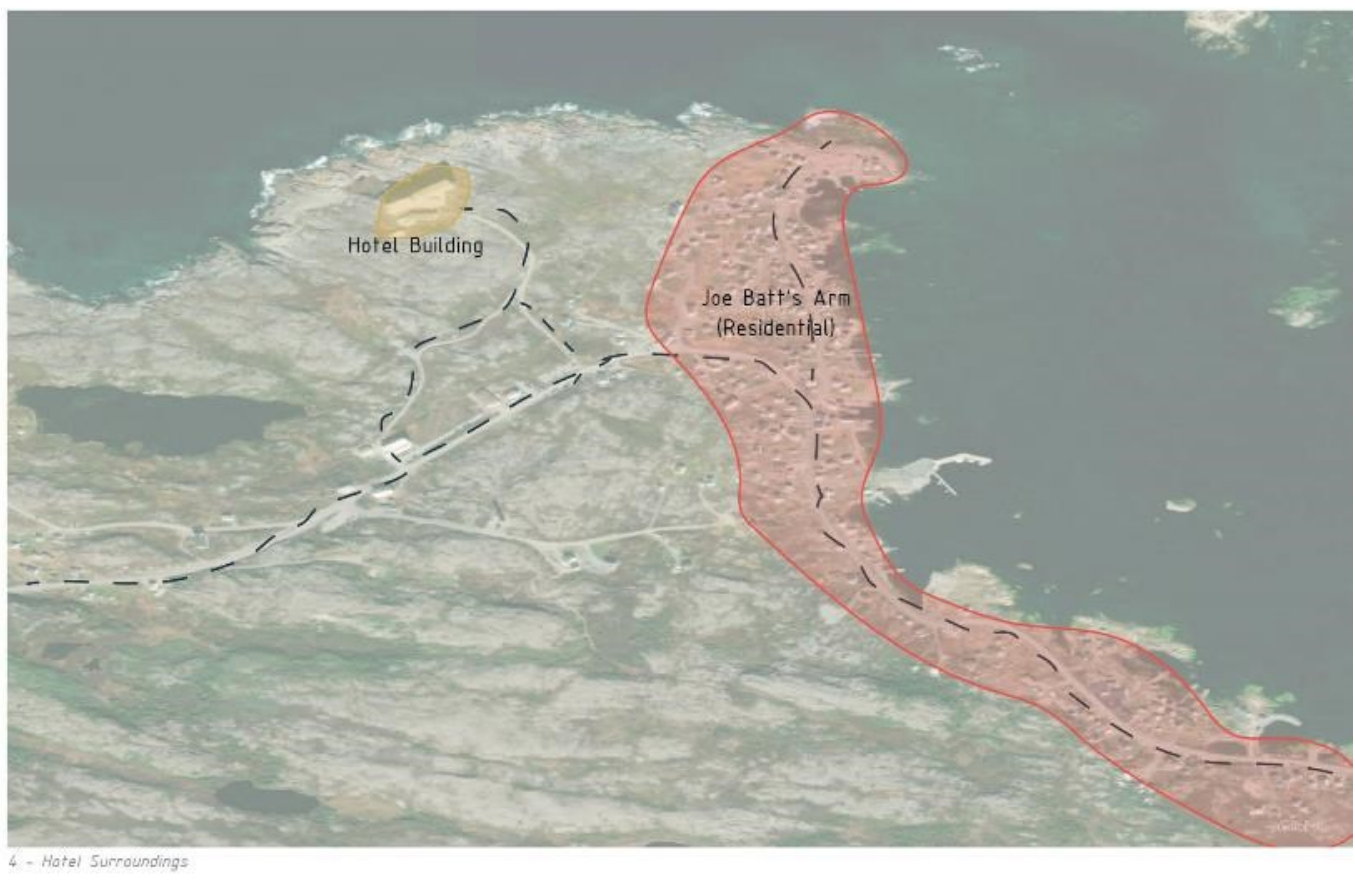


PROGRAM PRECEDENT

The Cheakamus Centre is a rural education centre focusing on environmental and Indigenous pedagogy. This precedent showcases how a well sited, aesthetically pleasing building will reinforce its existence and draw users from afar. From advertising its scenic setting, the centre has also become a host to a number of private events - from company retreats to wedding parties. This case study serves as an inspiration of how to engage the built environment into the landscape. Even a small scale interventions can be possible with thoughtful programming.
CHEAKAMUS CENTRE Squamish, British Columbia

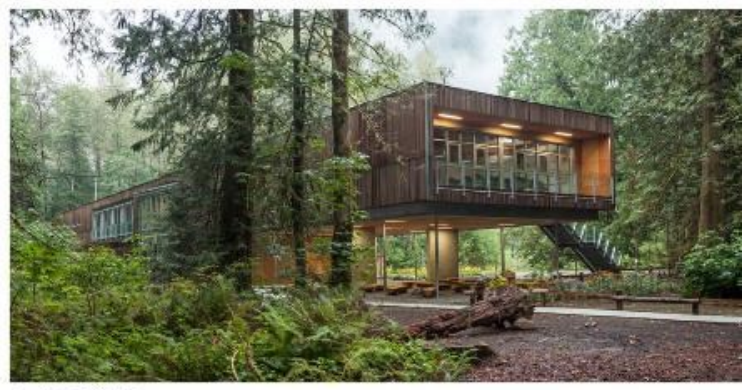

- Main building

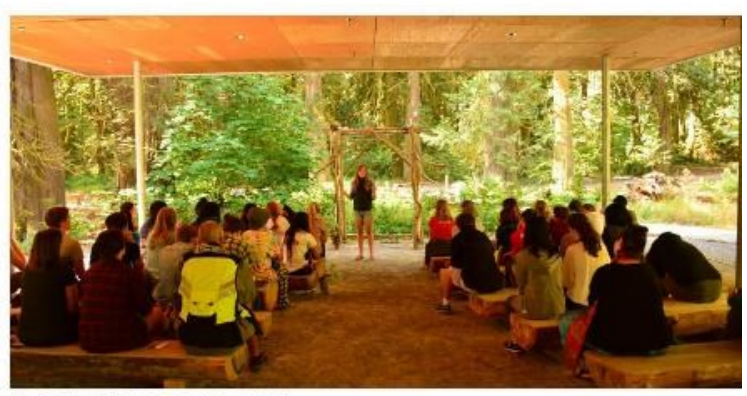

2 - Outdoor Classroom enviranment

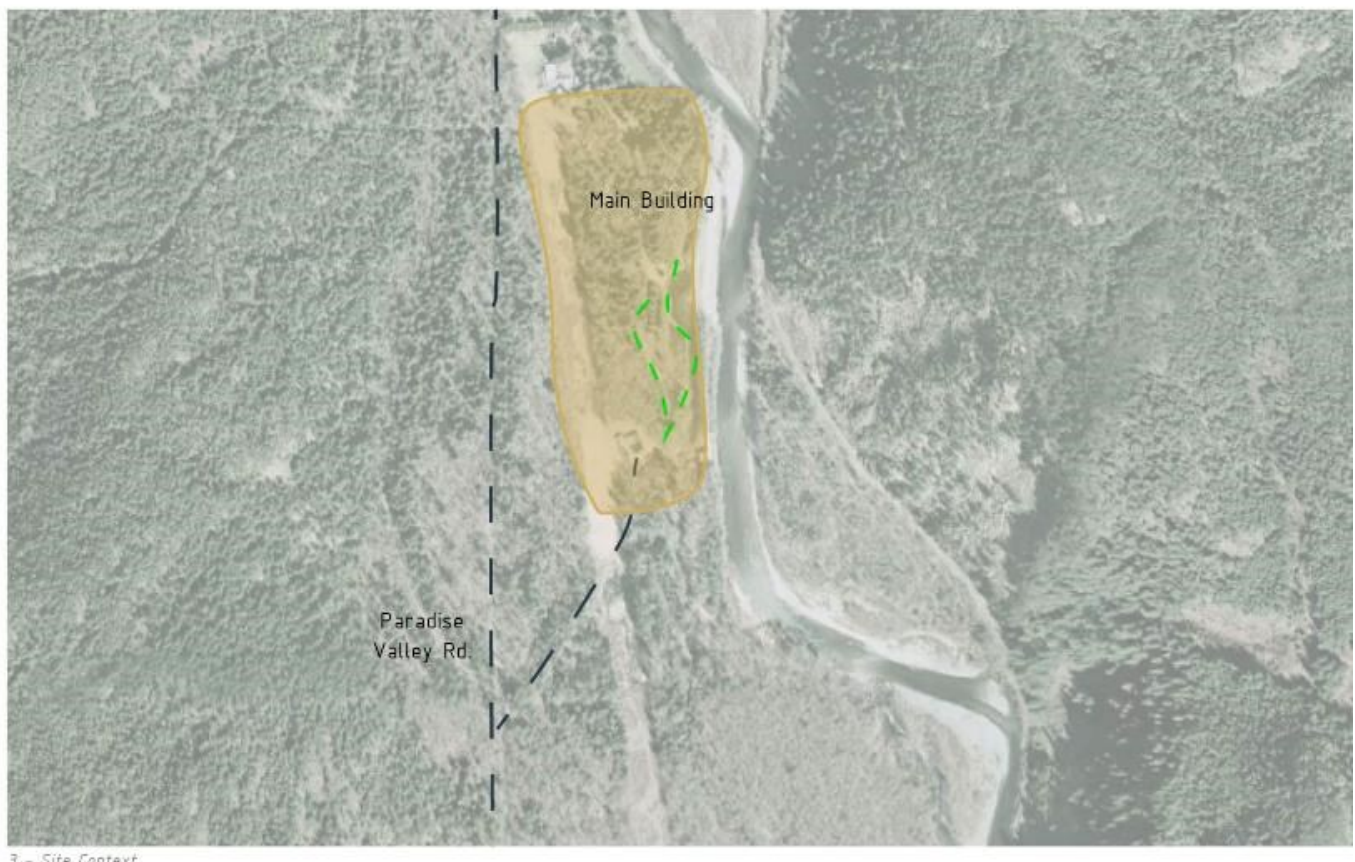

3 - Site context 
QUEST UNIVERSITY

Squamish, British Columbia

Quest University is a post-secondary institution, specializing in a unique undergraduate curriculum. The campus is located on a West-facing hillside, providing close access to nearby recreation sites.

While Quest has shown the potential for post-secondary programming in a small community, the high capital costs to build the institution were offset with the development of the surrounding neighbourhood. This has led to financial issues only a few years into incorporation. As well, the campus is not within walking distance of established commercial centres, leaving students to depend on vehicular or public transport for access. This case study shows the importance of active transport and appropriate siting.
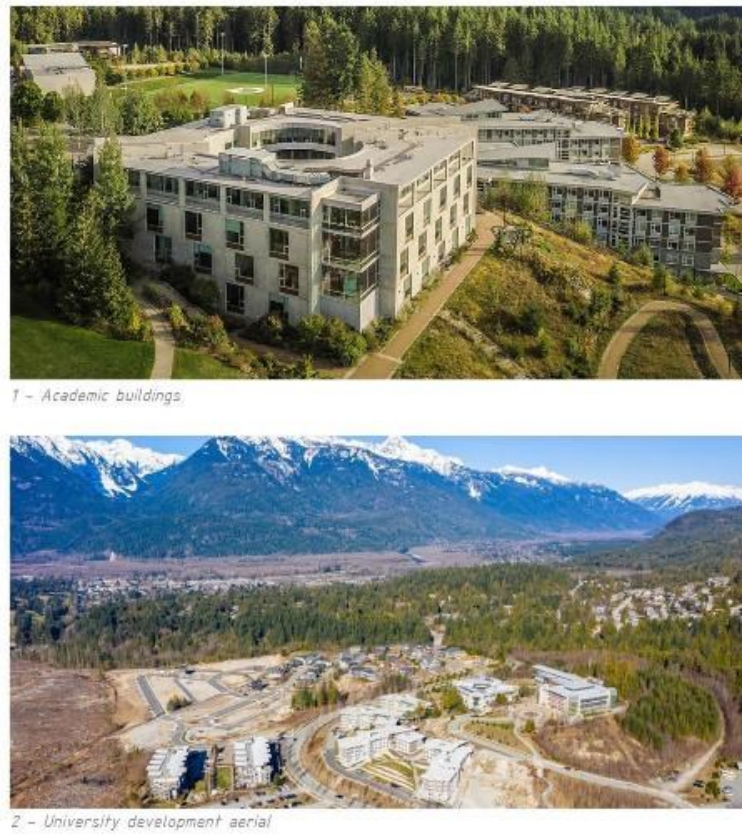
The Wood Innovation Design Centre is a pioneering example in tall mass timber construction. The centre hosts a Masters of Wood-Engineering program. Given that Prince George is the northern capital of industry in British Columbia, there are lessons to learn from these achievements.

This project in particular contributes to the ethos of the proposed education trades facility in Nakusp. In turn, this construction method could be of reference in the Lower campus. The buildings in the campus can act as a pedagogical tool - as a built example in an emerging construction technique. Investment in this technique would also contribute to the local industry by constructing with locally produced materials.
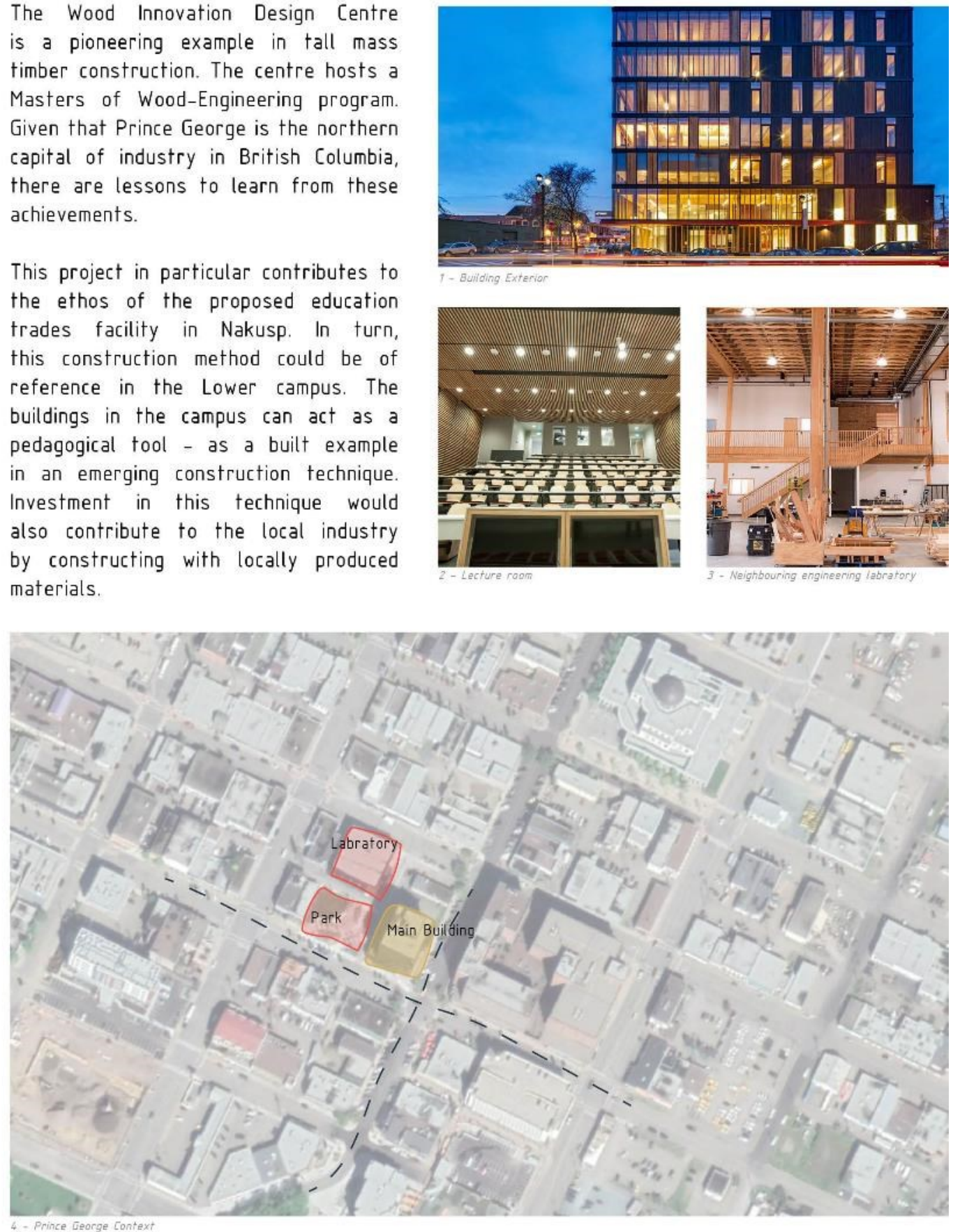


\section{PROGRAM PRECEDENT KWANTLEN POLYTECHNIC UNIVERSITY}

Langley, British Columbia

Kwantlen Polytechnic University is a post-secondary institution based in a number of campuses across metroVancouver. The university offers both degree-based undergraduate programs and trade school curriculums.

The Langley campus, shown here, shares similar programs to the proposed educational institution in Nakusp. However, the Langley campus does not engage students to stay in close proximity to the campus. The campus is geared toward vehicular circulation. It is common for students at this campus to commute by car; the planning of the Langley campus reflects this. Given this, the programming offered at Kwantlen is better aligned with the needs of Nakusp and provides an example of an арргоргiate scale in the long-term.
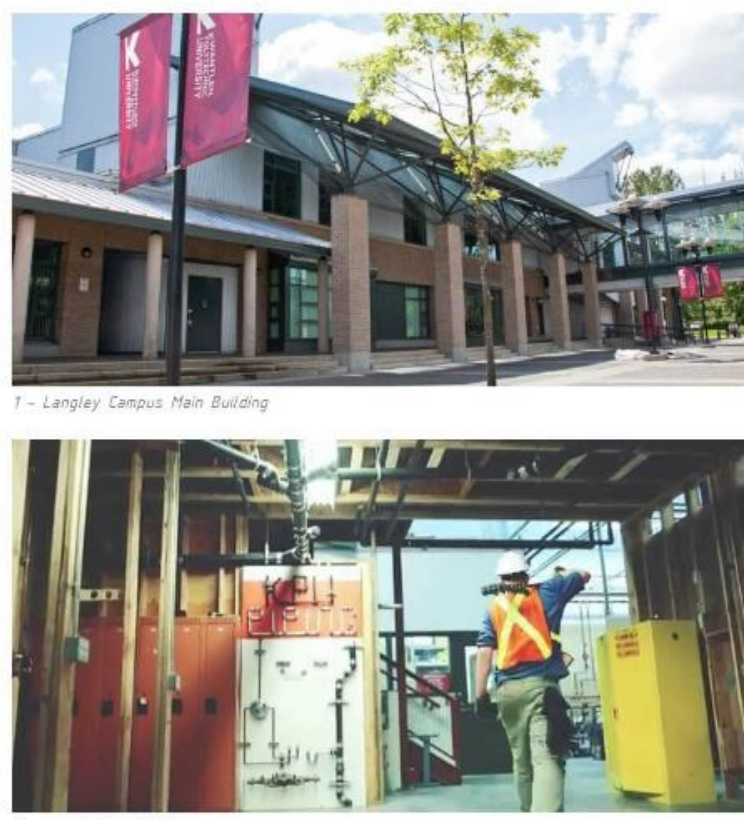

2 - Trades warkshop

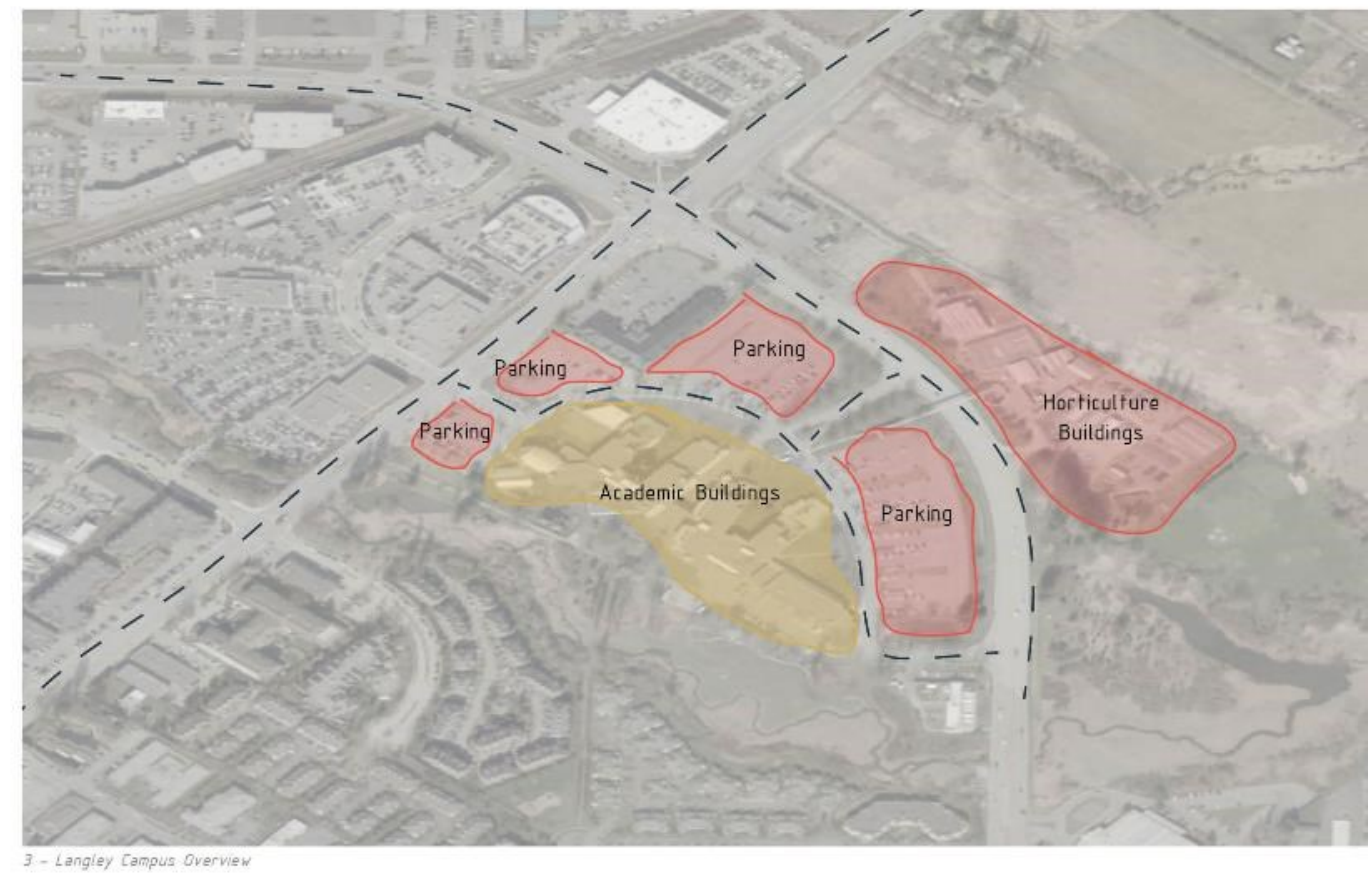


PROGRAM PRECEDENT

The Banff Centre for Arts and Creativity is a multi-disiplinary post-secondary institution located in the Rocky Mountains of Alberta. Located on the outskirts of town, the centre hosts a number of educational programs ranging across artistic disiplines. The campus hosts a number of lodging facilities, restaurants and supportive amenities such as a gallery and fitness centre. The Banff Centre also has the capacity to host conferences and summits.

This institutition is an excemplary postsecondary institution in a rural setting. While the Banff Centre has taken decades to grow to its current scale, its vision as a institution for gathering is a well-suited precedent for what Nakusp may become.

\section{BANFF CENTRE Banff, Alberta}
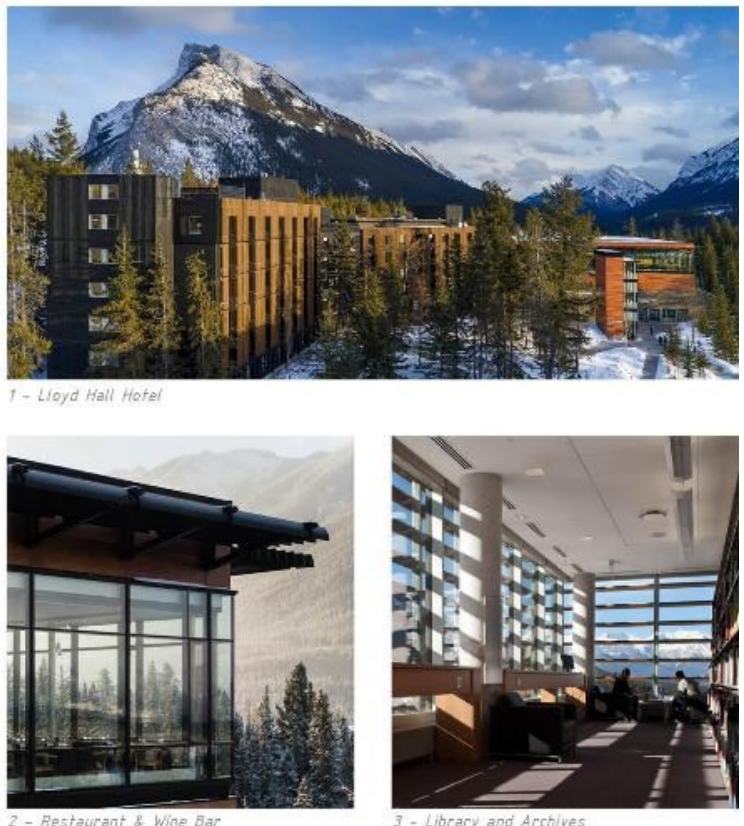

- Pestaurant \& Wine Bar

3. Libracy and Acchives

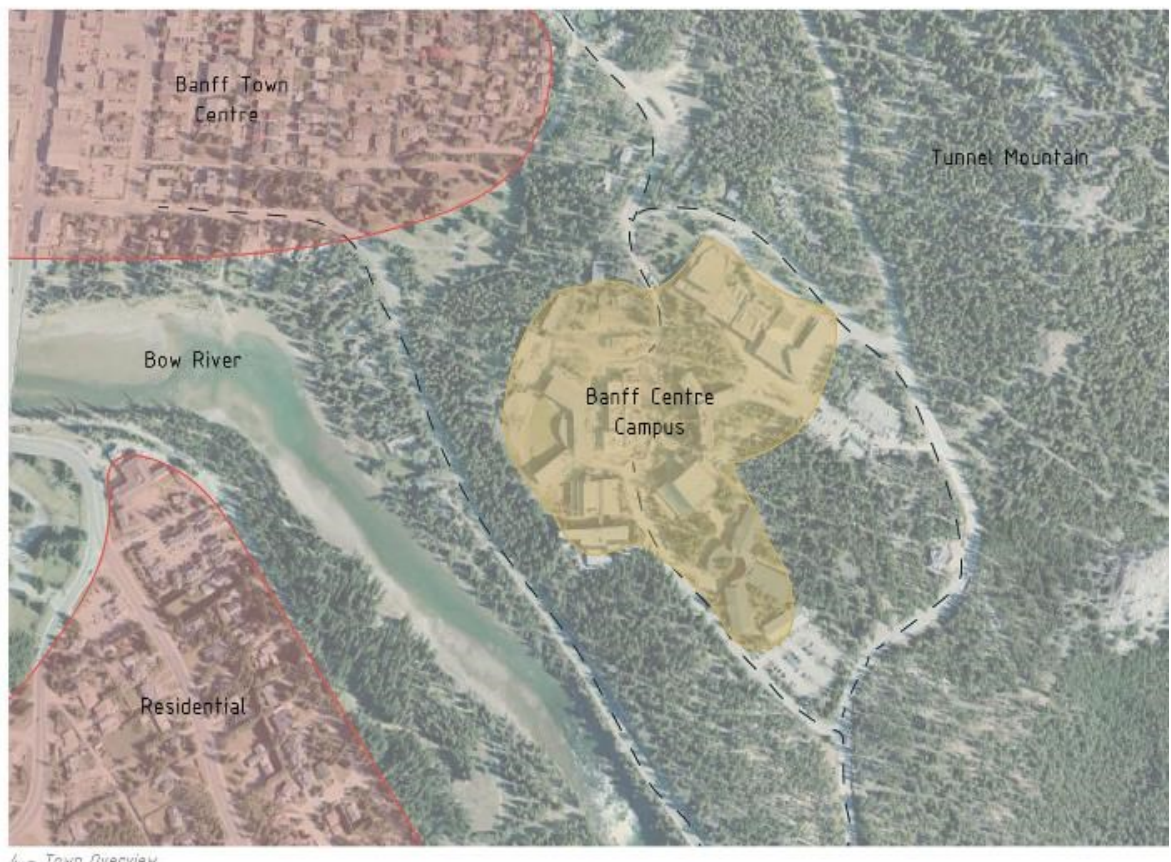




\section{PLANNING PRECEDENT}

Simon Fraser University is situated on Burnaby Mountain, with views overlooking metro-Vancouver. The strength of this precedent lies in its highly connected axial pathway. Foot traffic on the campus is prioritized, while vehicular traffic is reduced to circulation on the circumference of the campus. The integration of residences to academic zone contributes to its high walk-ability.

However, access to Simon Fraser is difficult for commuters. Access is limited to few roads on the southern face of Burnaby mountain. This puts a heavy reliance on public transport and creates a bottleneck condition at the entrance to the campus. This precedent shows the importance of integrating buildings closer to existing built out areas rather than remote locations.
SIMON FRASER UNIVERSITY Burnaby, British Columbia

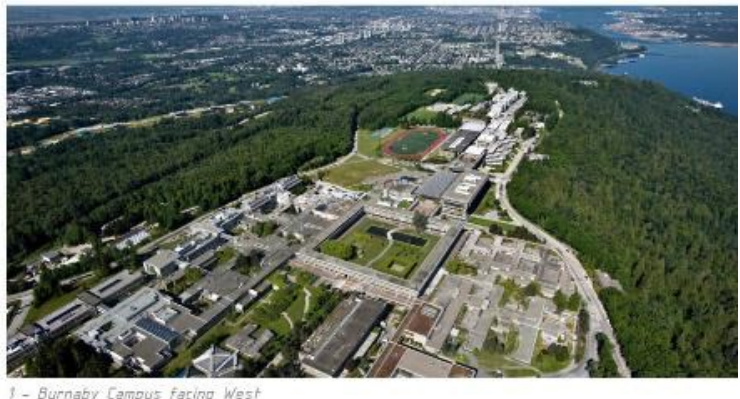

1- Burnaby Campus facing West

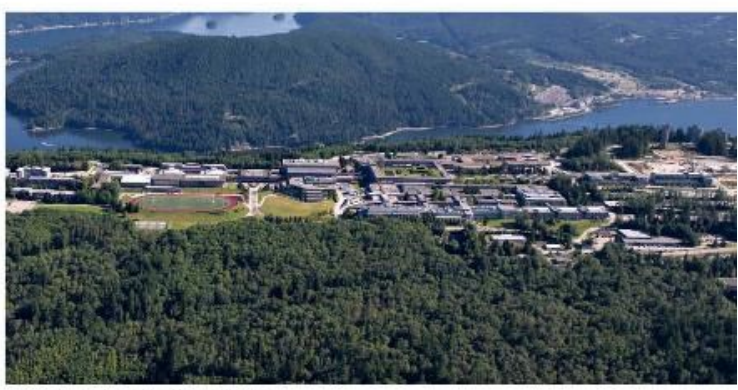

2 - Burnaby Campus facing North

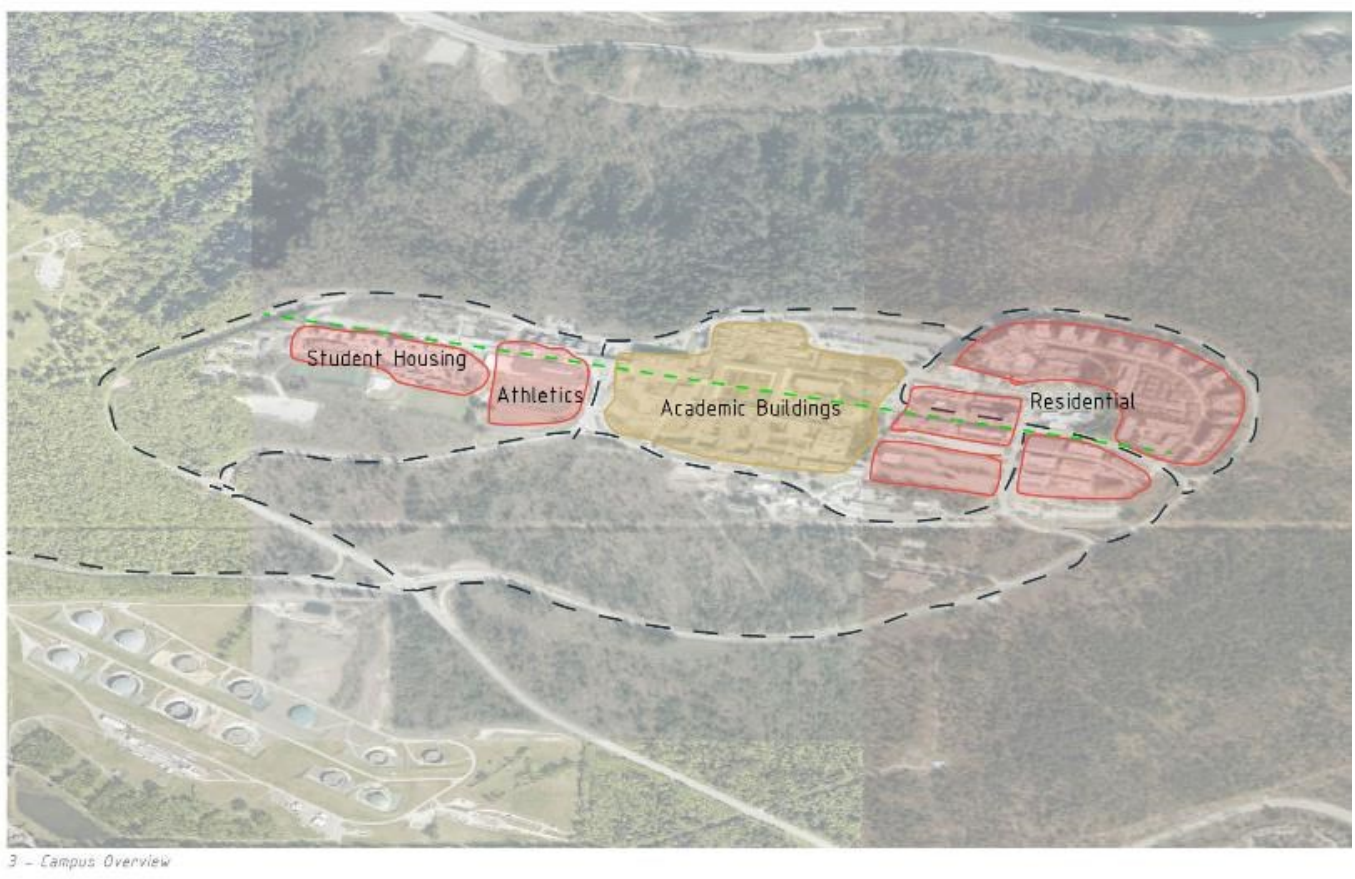


PLANNING PRECEDENT

While construction techniques will vastly differ between the Florida context and British Columbia, Seaside acts as a good precedent for residential planning in relation to a bounding water condition. The main vehicular access to the community is buffered from the beach by a row of residential plots. To maintain public access to the water, pedestrian corridors between residential properties are added along the length of the beachfront. Pavilions located at each of the access points act as visual reference to guide visitors. Buffer zones between the residential plots and water conditions generate additional park space - contributing to good integreation between natural and built landscapes.
SEASIDE \& WATERCOLOR

Seaside, Florida
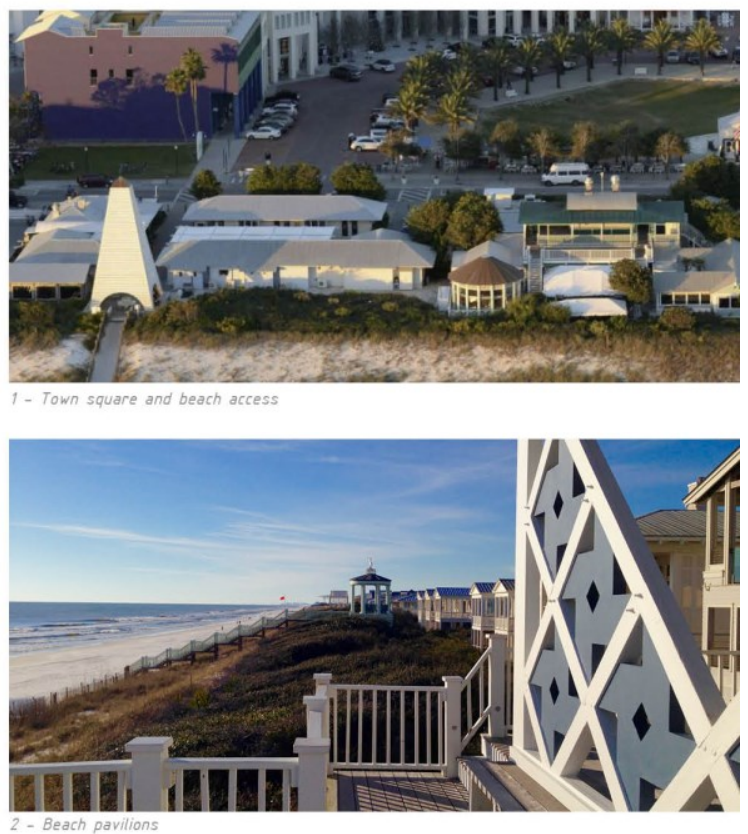

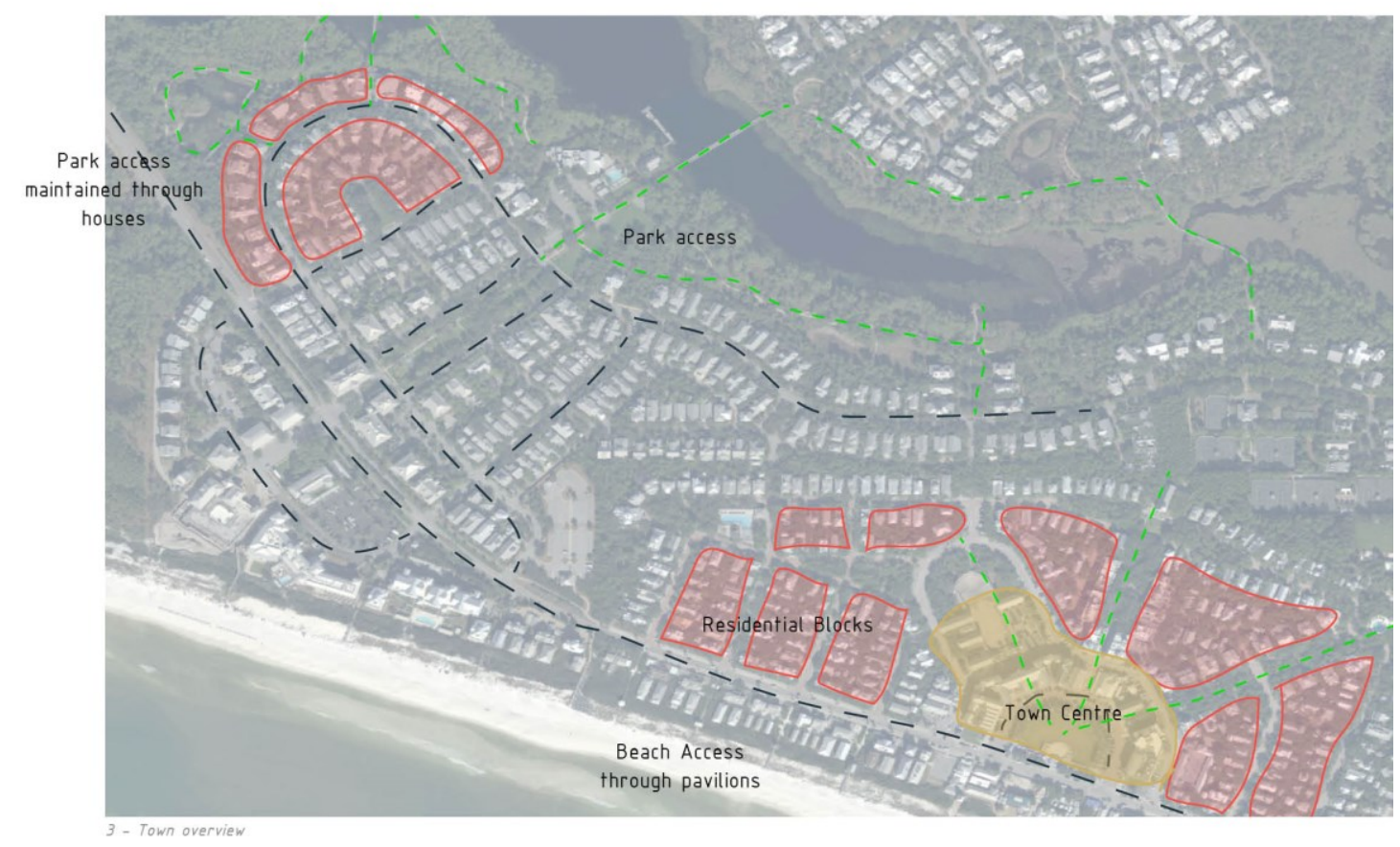




\section{UNIVERSITY OF BRITISH COLUMBIA \\ Vancouver, British Columbia}

The University of British Columbia is a suitable precedent given its emphasis on pedestrian circulation. Though this campus is large in comparison to the Nakusp proposal, this precedent highlights how a linear corridor unifies a campus along its length. As well, it provides examples of boundary conditions when traffic meets pedestrian pathways.

A pedestrian path, aptly named Main mall, runs the entire length of the campus. Plazas terminate each end of the mall, giving a visual геfегеnce point for navigating the campus. Secondary pathways perpendicular to main mall create tight academic blocks. These elements form a large pedestrian zone at the heart of the campus. Vehicle access into the academic blocks is controlled to the circumference of the pedestrian
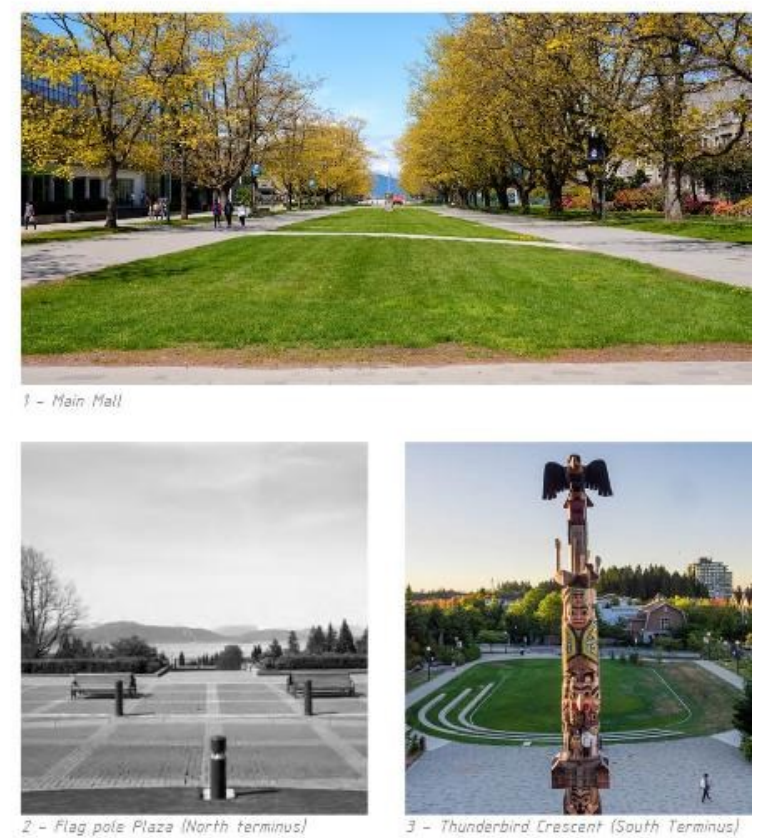
zone.

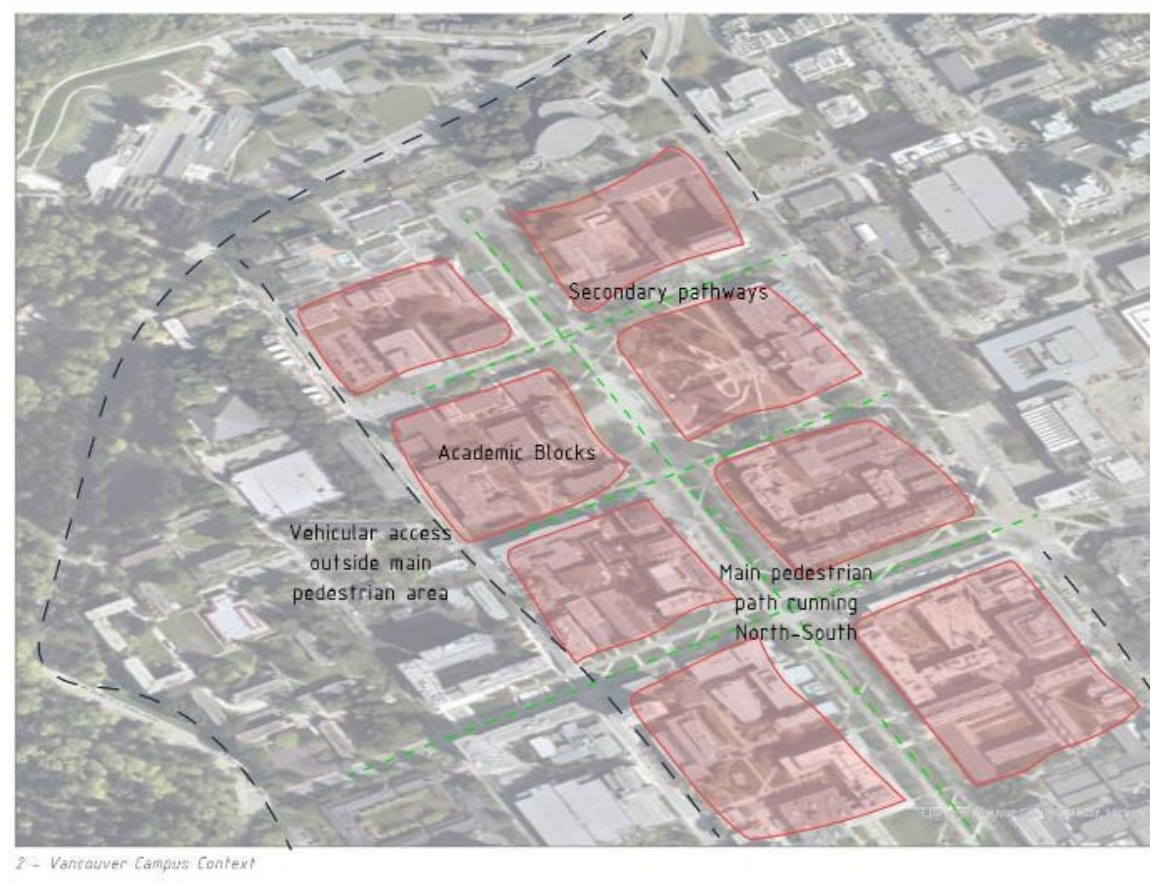


Whistler is an all-season resort municipality adjacent to a large ski hill. This case study provides good programmatic elements to include in the Nakusp proposal. However, Whistler is still heavily reliant on the sucess of the ski resort and tourism inflows to support local buisnesses.

The meandering village walk is the predominant means of circulation through town centre. Mixed-use buildings surround the village walk, creating a tight village atmosphere. Outside of the village, a paved valley trail network allows for active circulation throughout the valley, allowing access to recreation sites and surrounding residential агеas. Consistent wayfinding signage helps visitors navigate throughout the area.
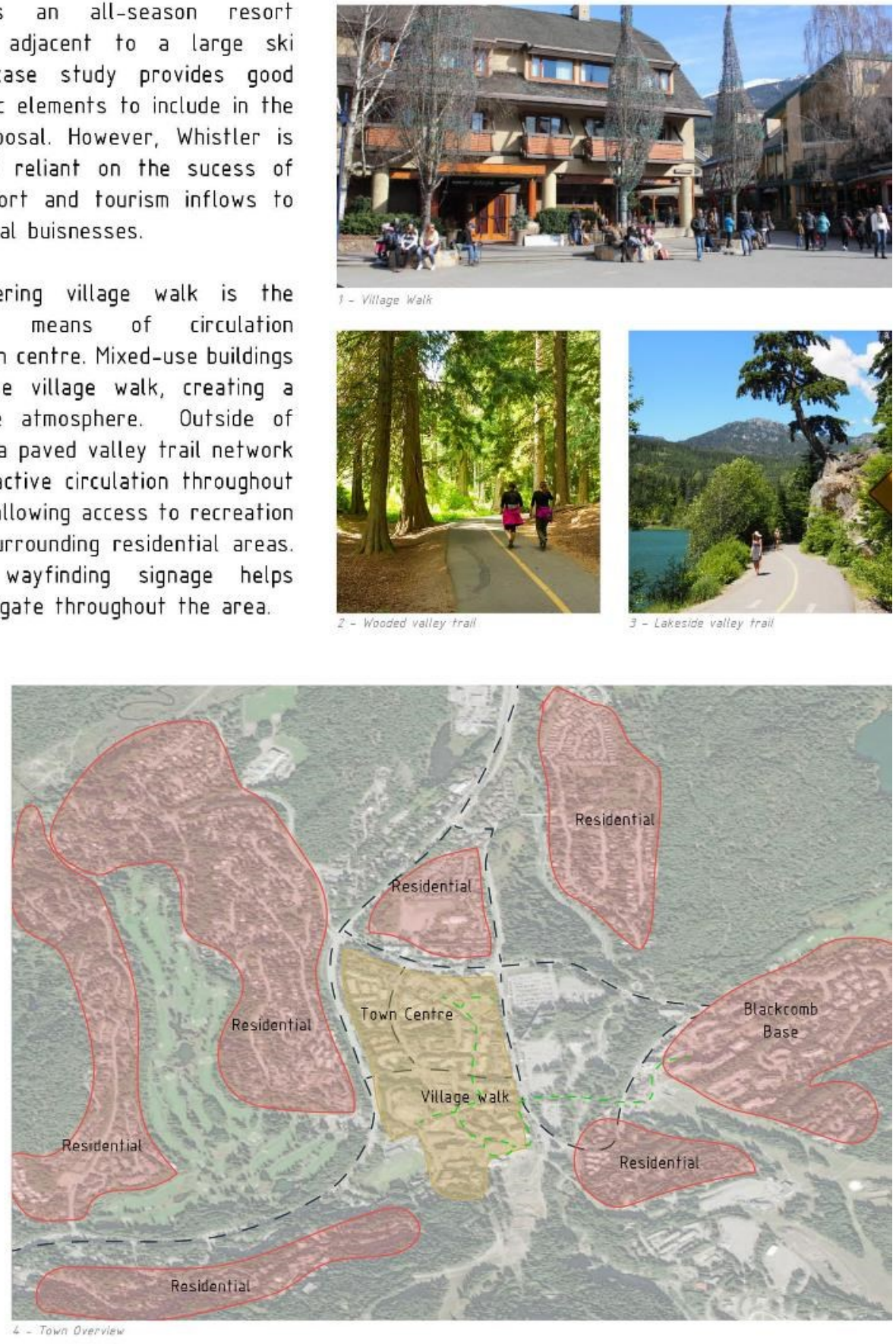
${ }^{38}$ Community Tourism Foundations, "Nakusp-and-Arrow-Lakes-Tourism-Plan-May-2009.Pdf" (Tourism British Columbia, 2009), https://nakuspareadevelopment.files.wordpress.com/2016/11/nakusp-and-arrow-lakestourism-plan-may-2009.pdf.

${ }^{39}$ Community Tourism Foundations, 4.

${ }^{40}$ Pheidias Project Management Corp., "Jumbo Glacier Resorts Proposal," accessed December 22, 2020. https://www2.gov.bc.ca/assets/gov/farming-natural-resources-and-industry/natural-resource-use/allseasons-resorts/jumbo/jgr-mp_2010.pdf.

41 "Termination of the Jumbo Glacier Resort Project," accessed December 22, 2020, http://jumboglacierгеsort.com/termination-of-the-jumbo-glacier-геsort-project/.

42 Village of Nakusp, "Nakusp-Zoning-Map-Sept-2019.Pdf," accessed October 8, 2020, http://nakusp.com/wp-content/uploads/2020/09/Nakusp-Zoning-Map-Sept-2019.pdf.

${ }_{43}$ Government of Canada, "Census Profile, 2016 Census - Nakusp, Village [Census Subdivision], British Columbia and British Columbia [Province]."

"4illage of Nakusp, "Economic_summit_final_report_november_2011.Pdf," 36.

45 "British Columbia Labour Market Outlook: 2019 Edition," 2019, 20.

${ }^{46}$ FP Innovations, "BIOPATHWAYS-II-Web.Pdf," accessed September 23, 2020, http://www.fpac.ca/publications/BIOPATHWAYS\%20ll\%20web.pdf.

${ }_{47}$ FP Innovations.

48 "Canadian Architects Declare Climate \& Biodiversity Emergency," Canadian Architects Declare Climate \& Biodiversity Emergency, accessed January 8, 2021, https://ca.architectsdeclare.com/.

49 "Wood First Act," accessed January 8, 2021,

https://www.bclaws.gov.bc.ca/civix/document/id/complete/statreg/00_09018_01.

${ }^{50}$ Ryser et al., "Moving from Mobility to Immobility in the Political Economy of Resource-Dependent Regions," 325.

${ }^{51}$ Village of Nakusp, "2021-Offical-Community-Plan-Reduced.Pdf," February 2021, 2, http://nakusp.com/wpcontent/uploads/2021/03/Schedule-A-Offical-Community-Plan-Reduced.pdf.

52 Village of Nakusp, 5.

${ }^{53}$ Village of Nakusp, 3.

${ }^{54}$ Village of Nakusp, 20. 


\section{0 - DESIGN PROPOSAL}

\section{1 - PHASED URBAN PLAN}

In keeping with the argument that resource-based communities need to diversify their economies, it became clear the ргoposal for Nakusp would be multi-faceted. In order to tie together the proposed рrograms while maintaining the character of the original town, the project shifted in scale from the design of a single building to a master plan for the community. The larger goals of the project were better геalized on the urban scale. Just as the principle of economic diversification necessitates reliance on more than one industry, this design proposal requires the insertion of more than one program. To coordinate these рrograms - both with each other and with the community as it exists -- a master plan is helpful. It offers the opportunity to focus on the different elements while devising a common language and cohesive narrative.

These different ргоject nodes are mapped to a long-term development plan. The phasing of the various programmatic elements should not be viewed as a true construction sequence. Rather, the phasing of elements should be seen as conceptual organization strategy to pair together dependent elements and capitalize on synergies. For example, the initial phase will consist of the development of the Uррег and Lower Campus nodes in concert with the north/south path connecting them to and through the downtown core. Without the simultaneous development of North-South pathway connecting campus агеa to the existing townsite, the elements become disjointed. One phase does not need to be fully resolved before other phases аге initiated.

The proposal is organized as a series of nodes connected by circulation paths (see fig. 24). These nodes correspond to what I consider to be арргоргiate development sites for the various ргоgrammatic elements. Two of these nodes border the Kuskunax creek just north of town - one on the north and the other on the south side of the creek. These аге labeled the Uррег and Lower Campus nodes, respectively as they аге the ргоposed location for the educational institution. Key to the scheme is a new north/south circulation 
path connecting these nodes to each other and southward through the center of Nakusp to the waterfront.

Also ripe for redevelopment -- as a new residential агеa -- is a large parcel of lakefront land to the west. As this was the site of a former sawmill, I'll refer to it as the Sawmill Lakefront node. While accessible via Rt. 23 heading northwest, I'm proposing that this агеa also be connected to the centre of Nakusp through the westward extension of $4^{\text {th }}$ St by a multi-use active transportation pathway.

Finally, I've identified two nodes that I believe to be suitable for new industrial uses. The first of these is at the intersection of Airport and Hot Spring Roads north of town, bordering the Upрег Campus node. The other, located southeast of downtown along the lakefront, is currently being used for industrial uses. To facilitate the further development of this site, I'm proposing a new connection between Highway 6 heading south and Highway 6 heading east through an abandoned railway cut.

When proposing connections, it's important to consider a range of modes of transportation, privileging active modes such as walking and cycling. Part of the small-town appeal of Nakusp is the ability to get around on foot, assuming the infrastructure is in place to encourage this. Pedestrian and multi-use pathways can act as catalysts for linear growth and can provide a means for drawing new residents to the community. ${ }^{55}$ They also minimize the importance of owning a саг in а гuгal community and change the way people engage with the local surroundings. 


\section{2 - SITE SELECTION}

\section{EXISITING TOWN INVENTORY}

Having identified sites and chosen programmatic elements, the next step is to tie them relate them to the existing village. Assuring that new development complements the existing town is critical. A town inventory was created to better understand what's there and where. Using aегial photography and zoning bylaws, buildings were classified into eight major categories: education, cultural, commercial, government, worship, residential, institutional, industrial (see fig. 22). The cultural category, shown in blue, includes гесгеational facilities include the hockey агеna, as well as the local Royal Canadian Legion and the Rotary club. Government buildings, in brown, include the RCMP station, the firehall, and the municipal services yard.

A second inventory map (see fig. 23), shown without residential land uses, gives a cleareг picture of how land uses аге grouped. Most of the public buildings аге located along Вroadway through the downtown core, and along the north-south highway corridor leading into $6^{\text {th }}$ Ave. Broadway acts as a main commercial-retail spine for the community. $6^{\text {th }}$ avenue acts as a main collector road to direct traffic into the downtown core.

While all of the proposed development nodes I have identified are on the регірhегу of town, it is crucial that new development enhance the existing downtown core. The town's bylaw documents include proscriptions against development along the highway corridors leading into the village. ${ }^{56}$ One can interpret this as an attempt to discourage large format retailers from locating on the outskirts of the community and siphoning business away from the downtown core. 


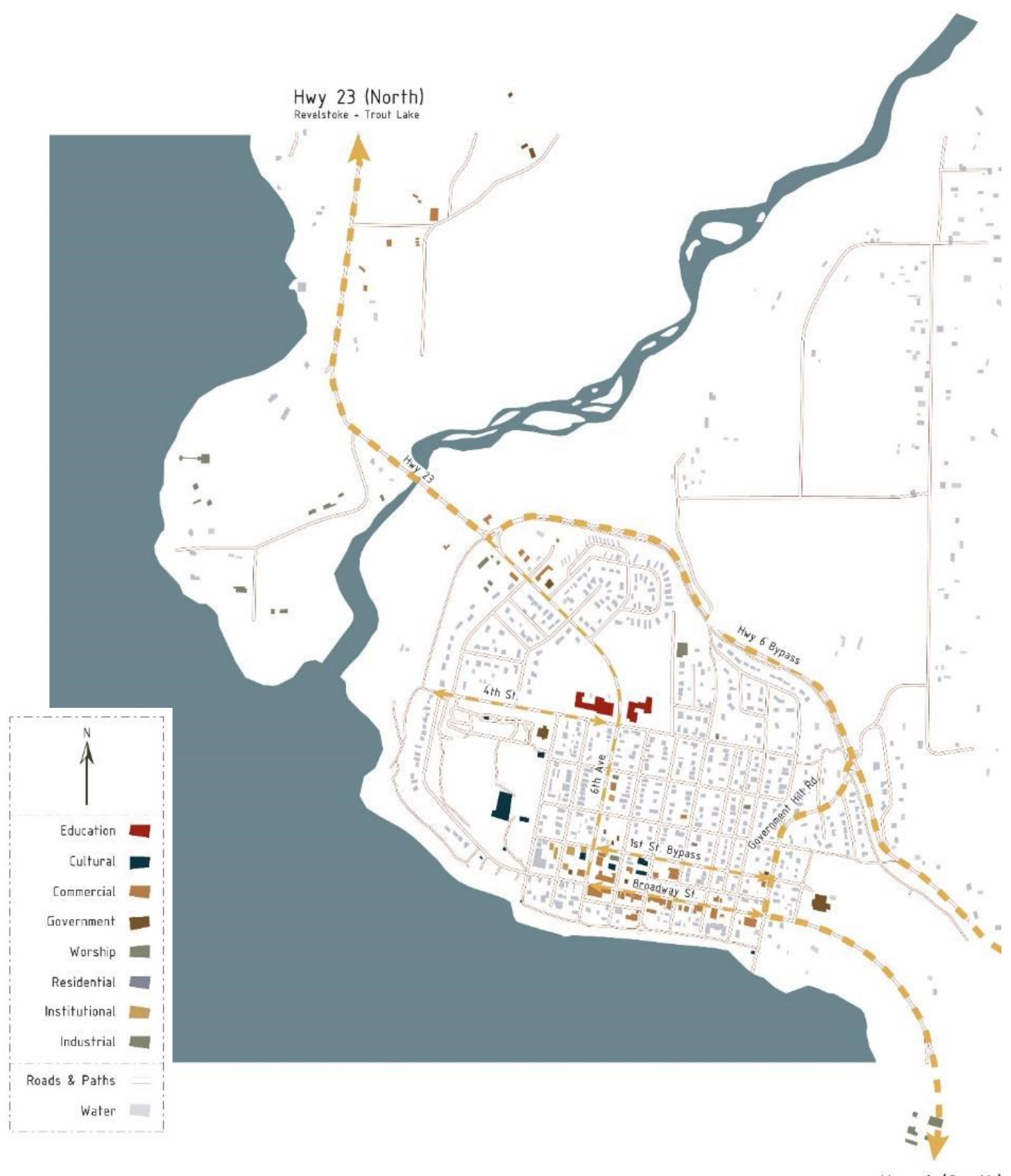

Hwy 6 (South)

Fig. 22 - Town Inventory 


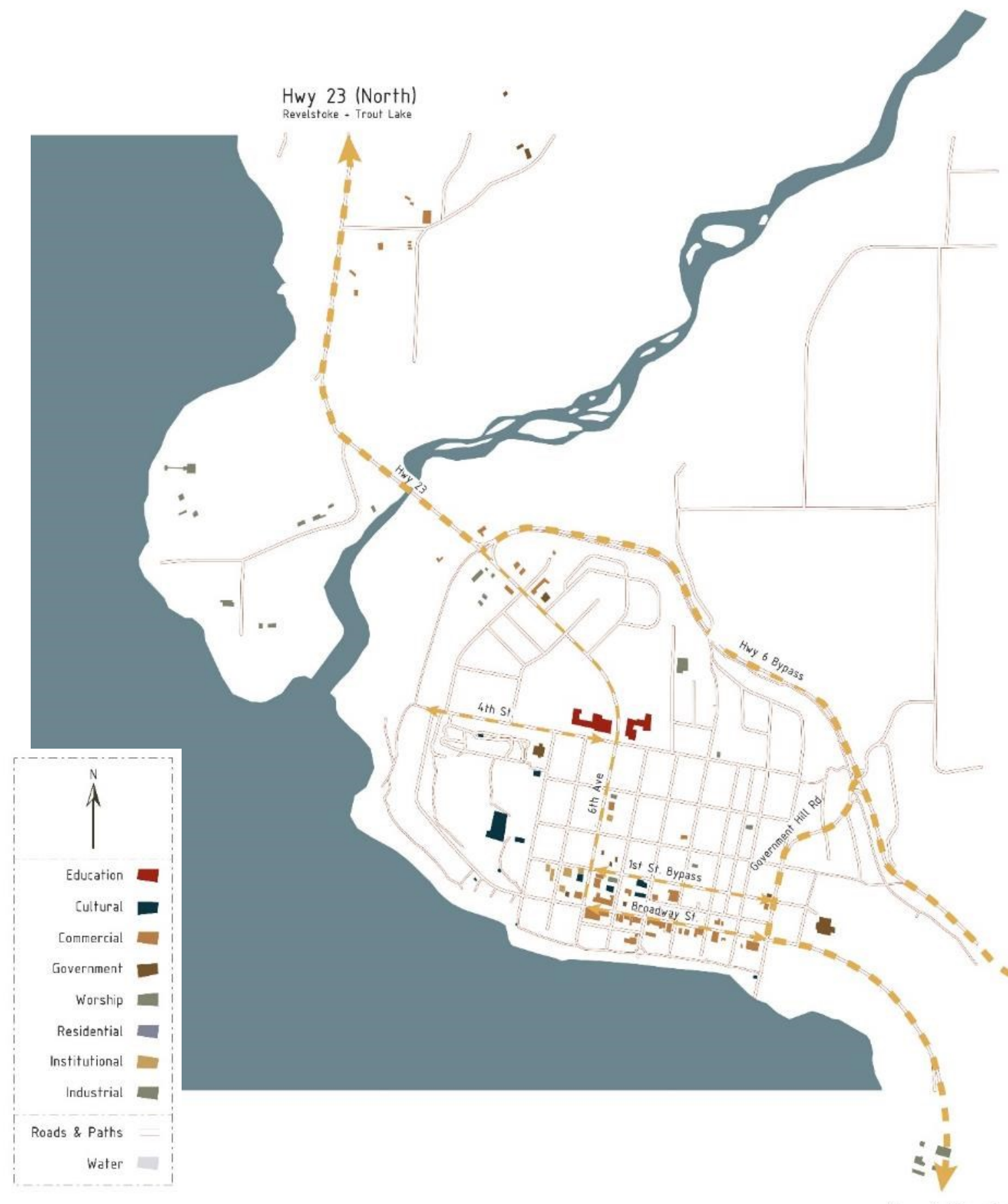

$\underset{\text { Burton }}{\text { Hwanguier }}$ (South)

Fig. 23 - Town Inventory without Residential Buildings 


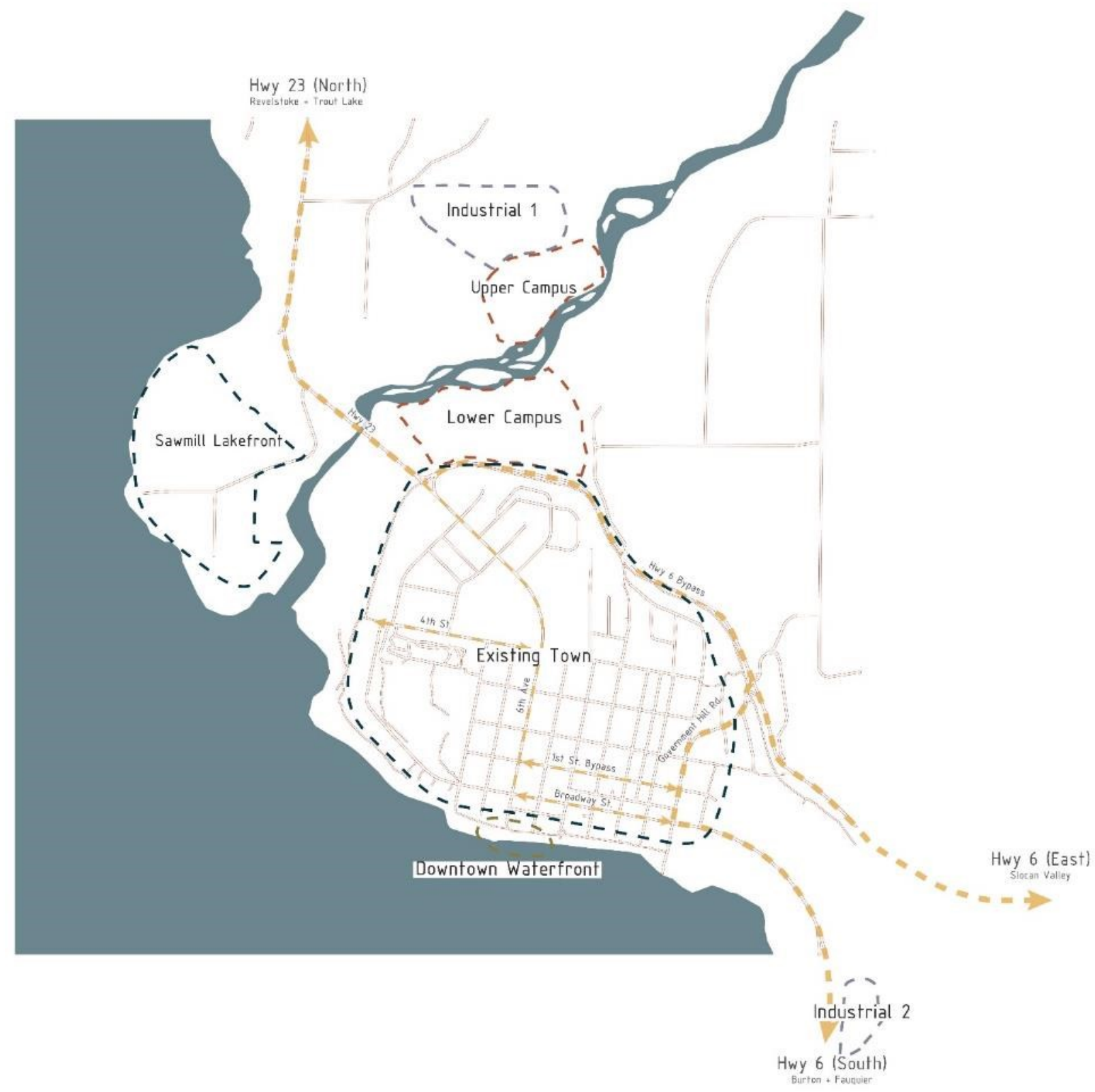

Fig. 24 - Site Selection - Key Map 


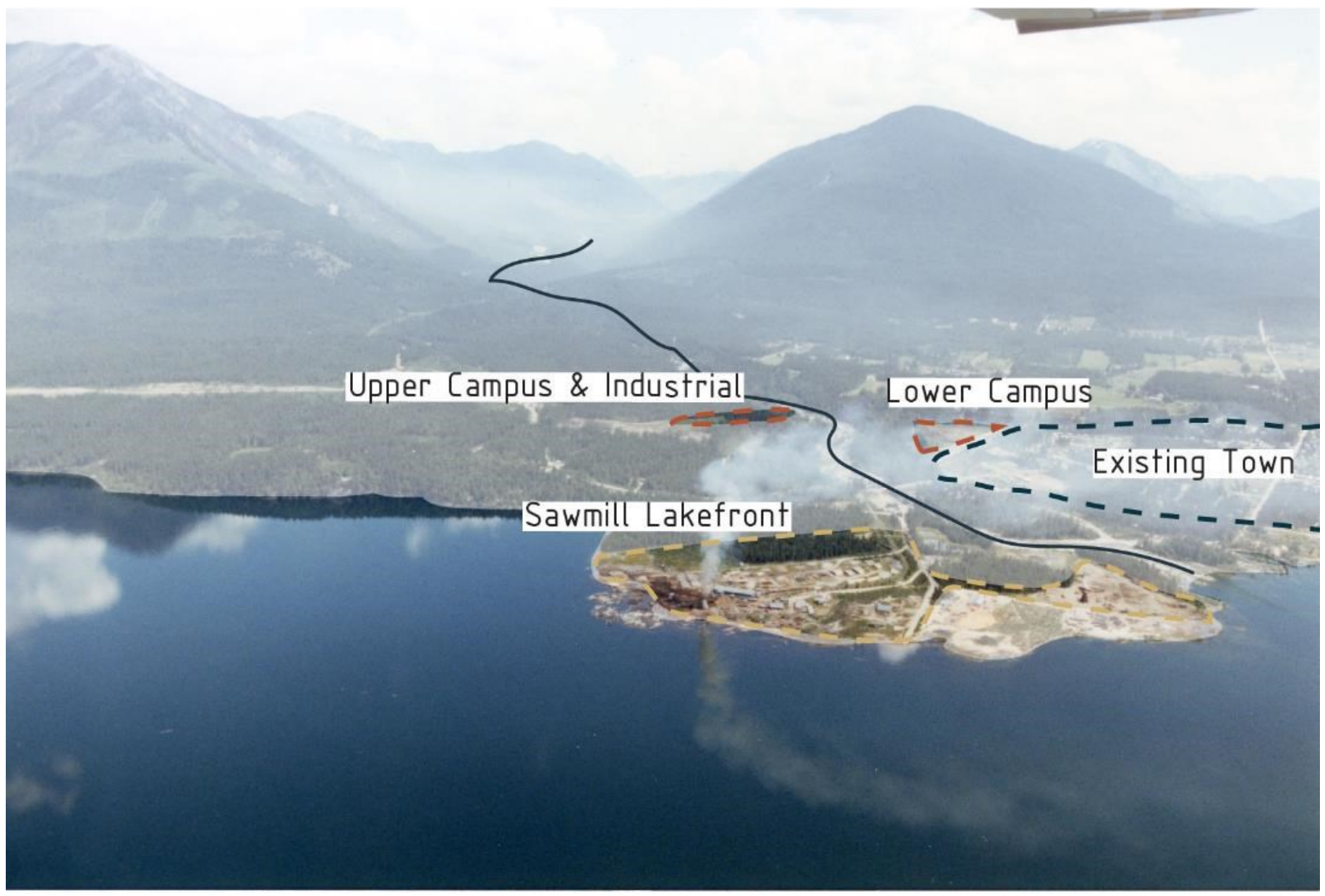

Aerial view of Kuskanax Point, Upper Arrow Lake at Nakusp, 1981. Columbia River Shake \& Shingle mill at centre. Chernoff Bros. sawmill at bottom right. Nakusp Airport below Kuskanax Mountain at centre left. Valley of Kuskanax Creek at top centre. Mount Jordan at top right above Glenbank. North Nakusp at centre right. - Arrow Lakes Historical Society

CREATOR: Milton Parent

IMAGE DATE: 1981

SOURCE: https://alhs-archives.com/document/2016-003-207-37-shingle-mill-nakusp-1981-c58-b-12/ 


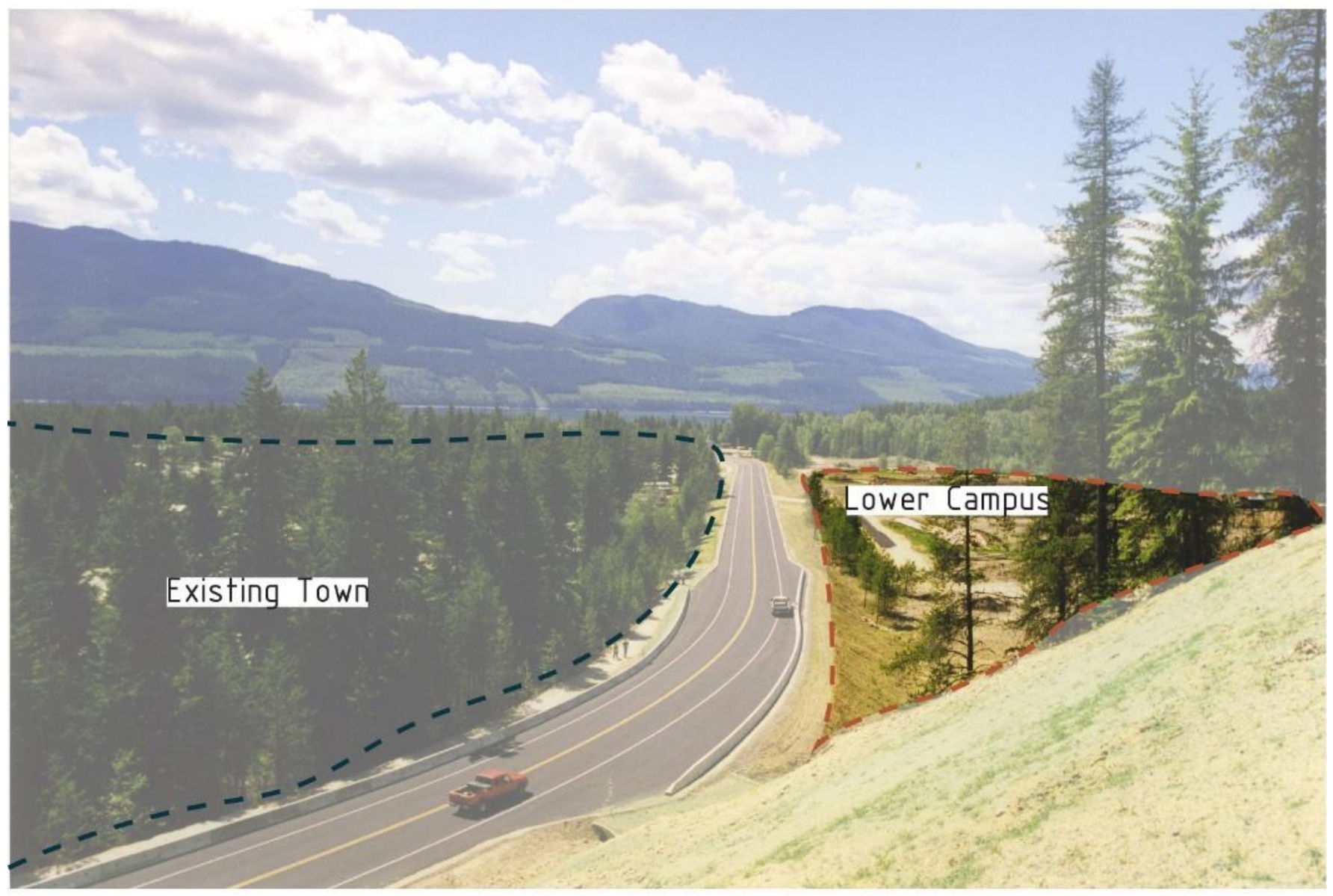

View from trail at top of Stevie's Hill (remnants of west end of Glenbank Road) looking down on new Highway 6 bypass around north end of Nakusp, opening day of highway, 16 June 2000. View is looking west toward PIPPCO pole yard. - Arrow Lakes Historical Society

CREATOR: Milton Parent

IMAGE DATE: $2000-16-06$

SOURCE: https://alhs-archives.com/document/2016-003-203-c182-21-opening-new-by-pass-nakusp-june-16-00/ 


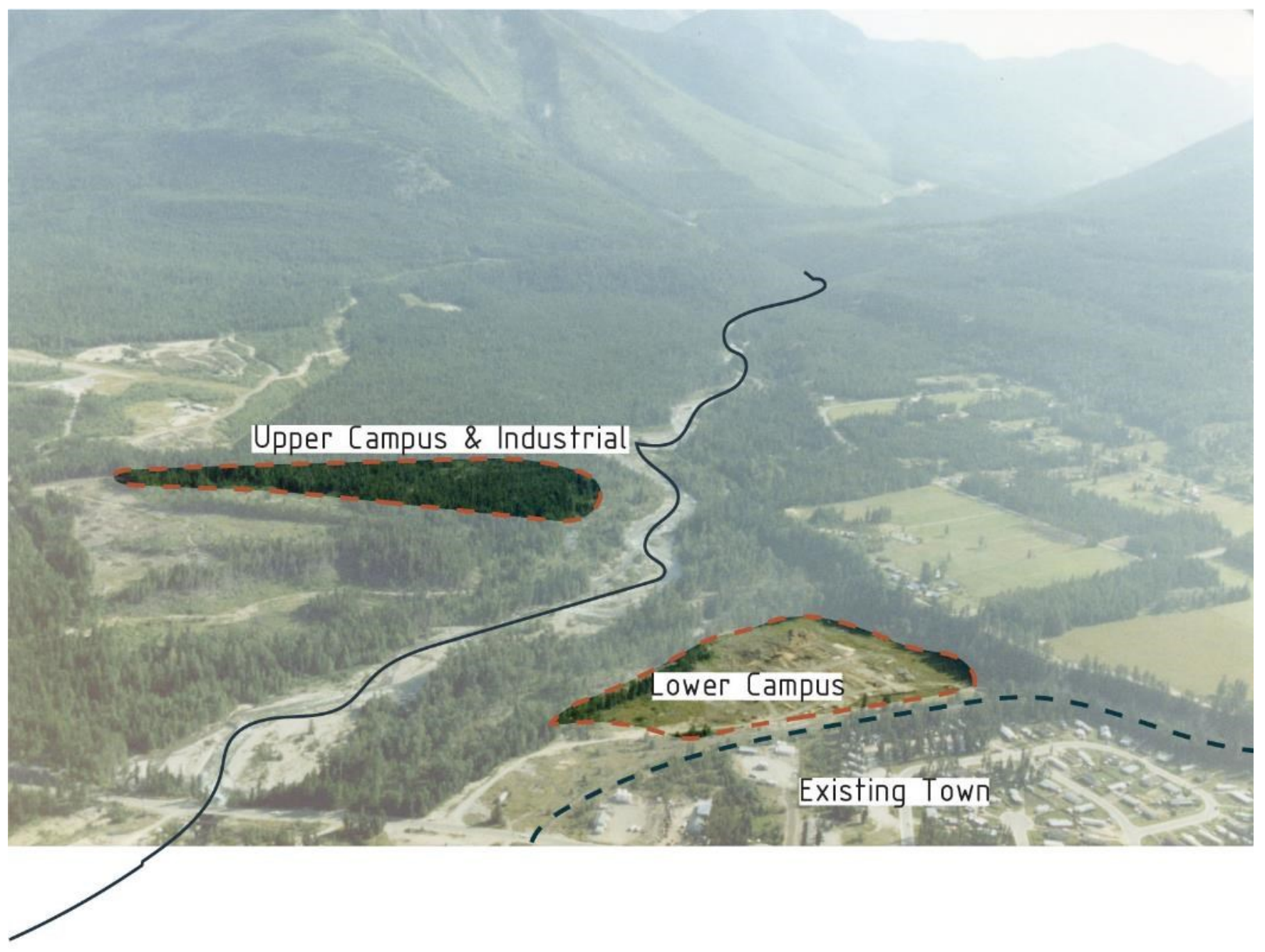

Aerial view of Kuskanax Creek looking northeast from above Nakusp, 1981. Nakusp Airport at centre left. Hot Springs Road runs along north side of creek from airport below slopes of Kuskanax Mountain. North end of Glenbank at centre right. PIPPCO poleyard and Columbia Heights neighbourhood of Nakusp at bottom right. Highway 23 at bottom left. - Arrow Lakes Historical Society

CREATOR: Milton Parent

IMAGE DATE: 1981

SOURCE: https://alhs-archives.com/document/2016-003-207-5-nakusp-1981-c58-a-6/

Fig. 27 - Site Aerial - 1981 


\section{UPPER CAMPUS \& LOWER CAMPUS}

As their name implies, the Upper and Lower Campus nodes will accommodate the facilities associated with the post-secondary institution. The Lower Campus will also include lodging facilities for visitors to the area. Locating the institution immediately north of the existing urban fabric will reduce the need to use private vehicles or public transportation to access the campus. At the same time, ease of access to the campus from Highway 6 will make it easy to service. The land on which the lower campus sits is at roughly the same elevation as the existing town - ensuring no significant grade changes along access pathways.

Siting the lower campus in this location creek makes excellent use of what's currently a brownfield site, owned and occupied by a telephone pole manufacturer (see fig. 26 \& 27). The flatness to the site coupled with the fact that it's under the control of a single owner would make the site еasier to асquire and redevelop. Educational uses аге also more complementary to the residential neighborhood across Highway 6 than industrial uses.

The Upper and Lower campuses straddle the Kuskunax creek, which is prone to occasional spring flooding. It creates a unique site condition that offers a close connection between the campus to the natural landscape and open up more of the land along the creek to геcreational uses. A pedestrian/cycling bridge across the creek - a node along the larger north/south path connecting the campus with the city -- connects the Lower and Upper Campus. Connection to the waterway via the bridge and гесгеation sites will create point of interest for both tourists and locals alike. Vehicular access to the upper campus is provided from the north via an extension to Airport Rd.

Dividing the educational programming across Kuskunax Сreek ensures adequate space for expansion. While the Lower Campus is constrained by the creek and the highway, the агеа north of the сгеek is more flexible. Могеover, locating the wood engineering ргоgгаm on the Uррег Campus encourages synergies with the proposed industrial site, immediately to the north. This is especially important for trade-oriented programs that involve handson experience. 


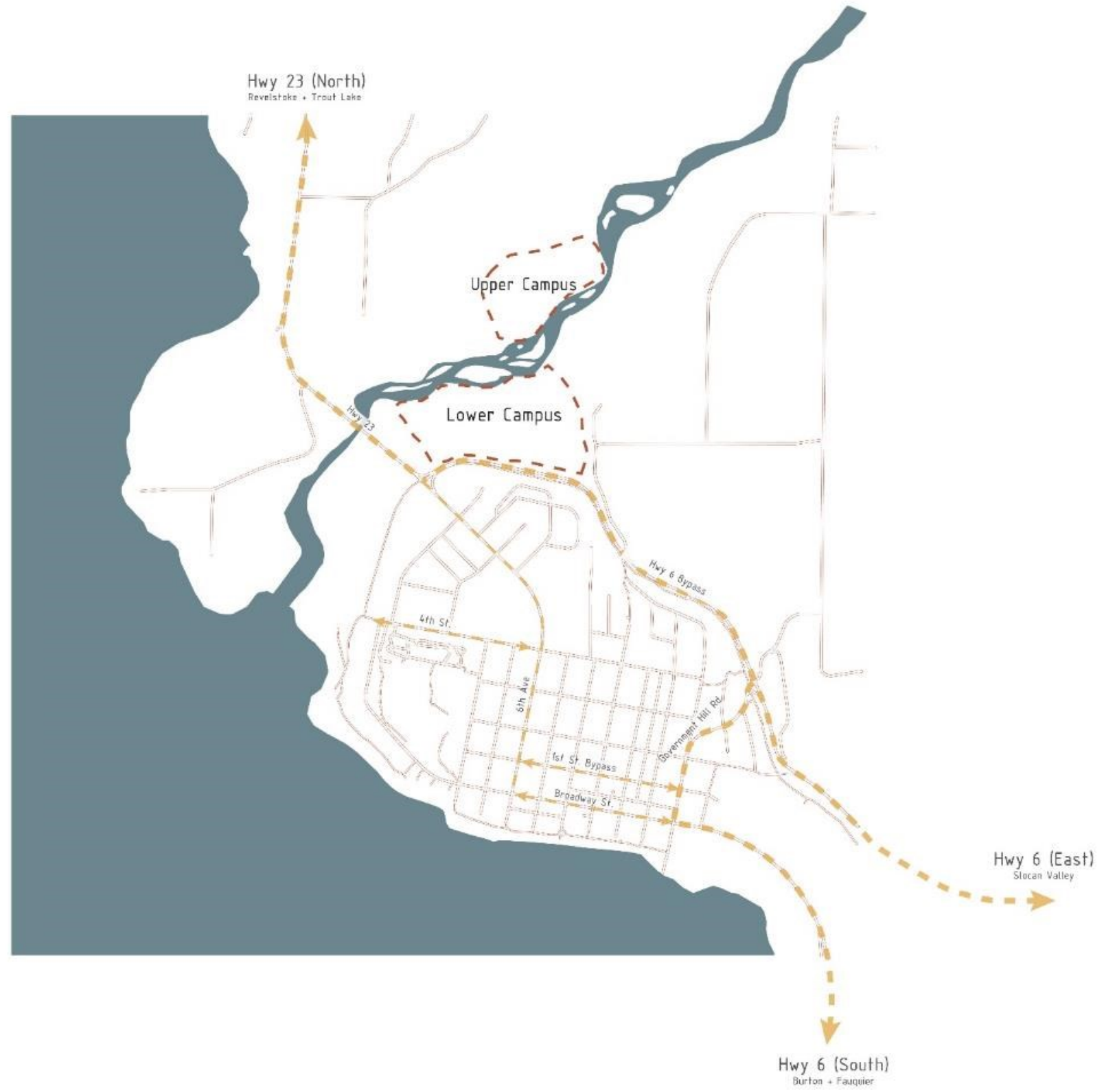

Fig. 28 - Site Selection - Upper \& Lower Campus 
SAWMILL-LAKEFRONT

The Sawmill-Lakefront Node will support a new residential neighbourhood. A 1981 aerial photograph shows area occupied by a range of industrial uses, with a plume of smoke rising from a factory (see fig. 25). At present, however, the sawmill and the shingle mill in the photo аге no longer operational, leaving the lakefront land mostly derelict. It is currently comprised of a mix of vacant lots, large residential properties and the municipal water treatment plant.

The lakefront peninsula is bounded by water on three sides. As with the creek dividing the Upper and Lower Campus, access to the lakefront offers potential for engaging with the natural surroundings. Situated on the waterfront, the site offers panoramic views across the lake to the peaks of the Monashee Range. A new residential district in this location, with a linear park along the shore, is an excellent use for the formerly industrial land. This residential district will help alleviate housing shortages the downtown core. If designed properly, this new district can accommodate a range of housing types to match the needs of a range of new residents, e.g., those involved with the educational institution, as well as young families and retirees relocating to Nakusp from larger metropolitan агеas. 


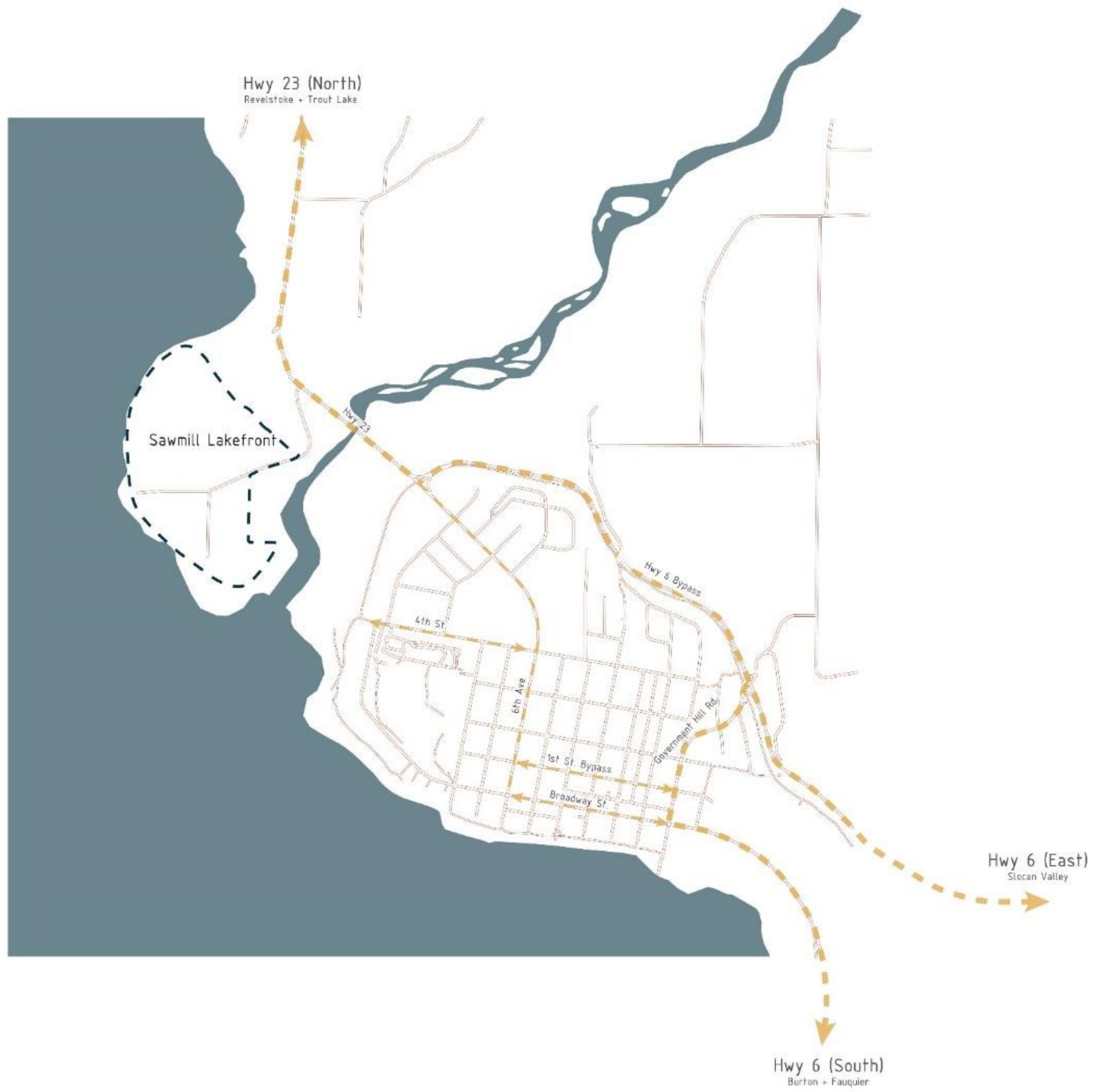

Fig. 29 - Site Selection - Sawmill Lakefront 
INDUSTRIAL SITES

As noted above, two nodes have been identified for industrial uses, i.e., as places to which to attract and accommodate the next generation of forestry-related industries. Ргіor to the flooding of the Агrow Lakes, industrial lands were located along the banks of the Columbia River. Logs were floated down the гiver and waterways were the ргіmагу transportation routes for people and materials. Dams along the river coupled with the use of trucks to transport materials means that there is no significant benefit for industry to be located along the lakefront. Adjacency to rail and road connections is more important.

The industrial site to the north of town, Industrial 1 (see fig. 30), is adjacent to the Upper Campus. As the Upper Campus will host facilities related to the trade and wood products curricula, pairing these land uses creates a new industrial zone buffered from the population centre to the south. Industrial 2 is located south of the townsite, adjacent to Highway 6. Both sites offer expansion potential for new or existing industries. 


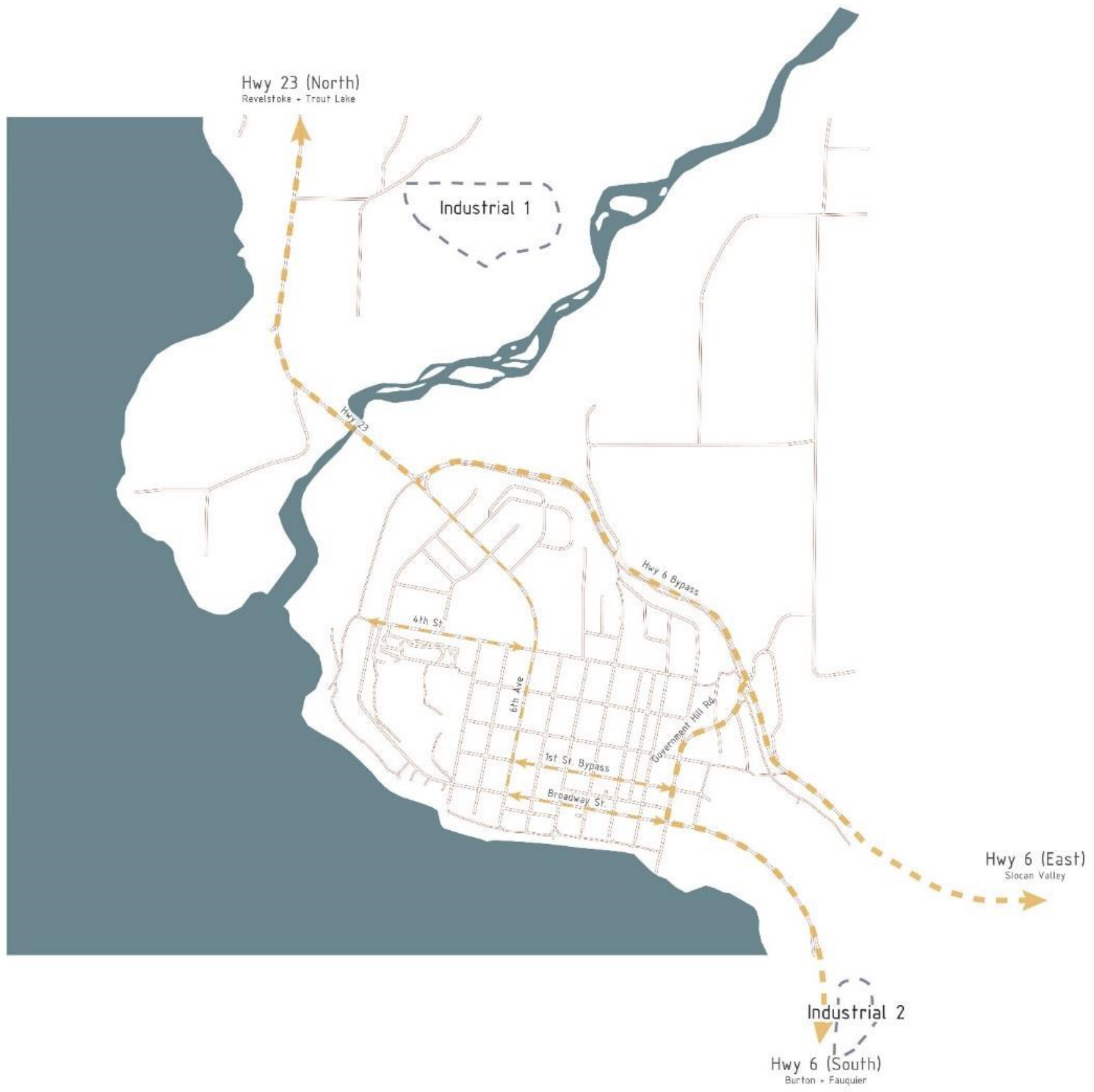

Fig. 30 - Site Selection - Industrial Sites 


\section{DOWNTOWN WATERFRONT}

As currently configured, it is difficult to engage with the lake along much of waterfront adjacent to the downtown core. The municipal public beach at the Western end of Вroadway Street and a floating wharf on the eastern end both offer гесгеation connections to the lake. But while a waterfront pedestrian path connects these two points, it is largely disconnected from the changing shoreline. As seen in Figures 8 \& 9, a steep embankment was created ргіог to the flooding to combat soil егоsion from the fluctuating waters levels. This paved pathway is bounded by a low guardrail on the southern side above the steep, packed embankment. Access to the lakefront is restricted to narrow concrete steps built into the embankment.

The ргоposed ріег at the southern end of $6^{\text {th }}$ Avenue will project across and beyond the existing shoreline (see Fig. 31). As designed, the pier will act as a mid-town access point to the lakefront - as well as a key municipal icon and amenity. The floating dock at end of ріег will enable гесгеational watercraft to access the downtown. This pier could be a catalyst point for water-based transportation on the Агrow Lakes and a gathering point for visitors to the community. 


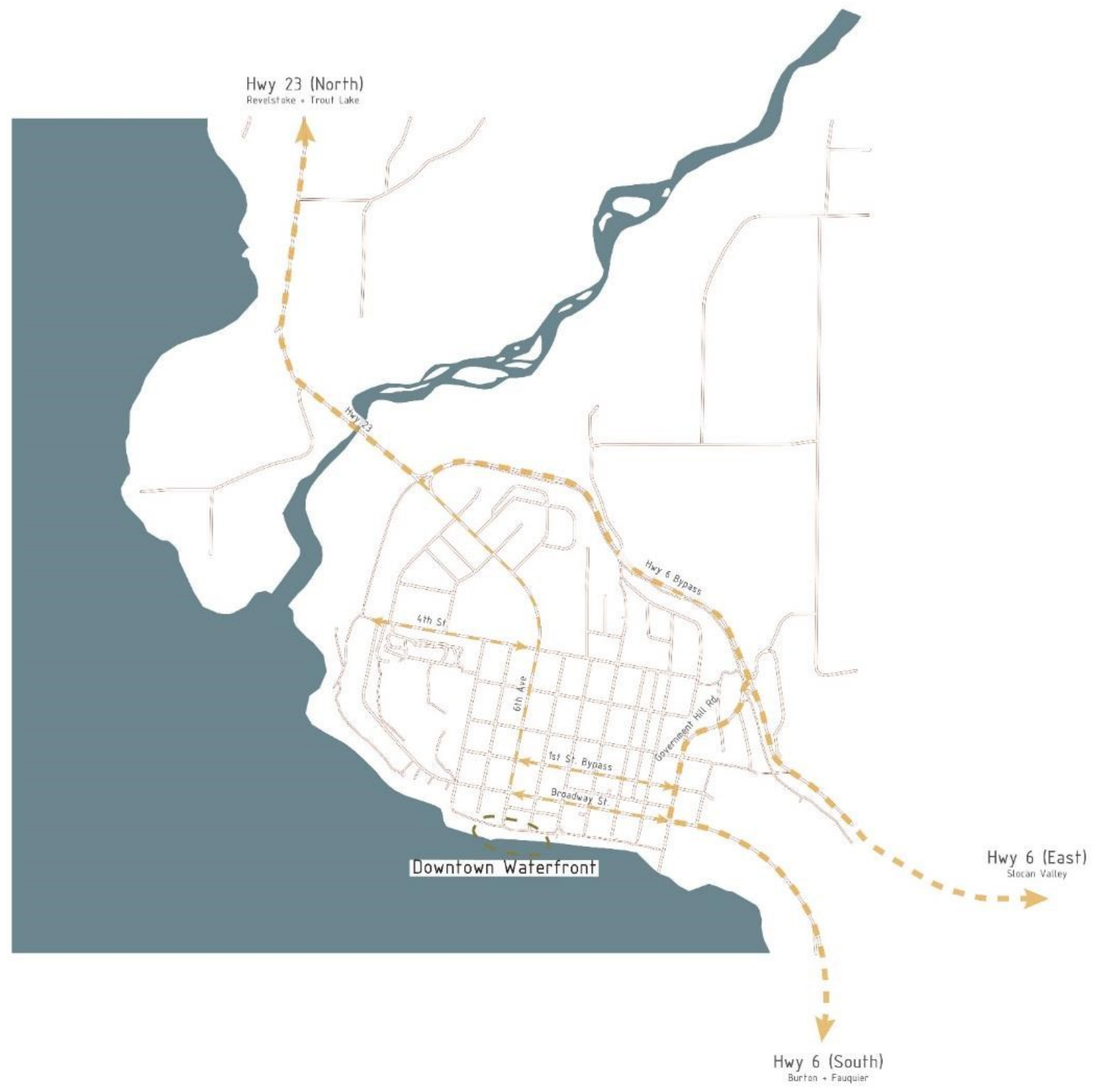

Fig. 31 - Site Selection - Downtown Waterfront 


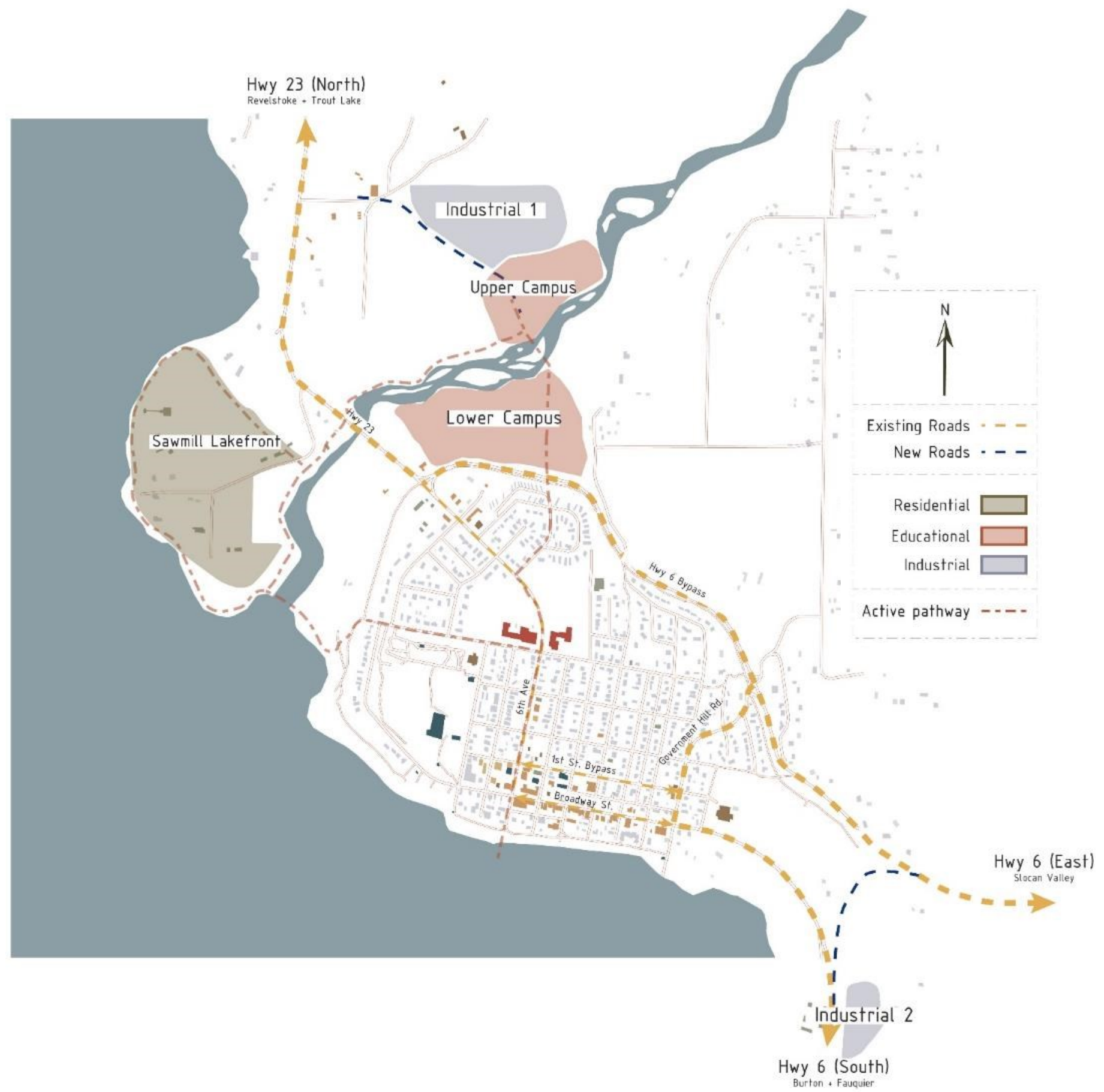

Fig. 32 - Town Urban Plan 
5.3-PHASE 1

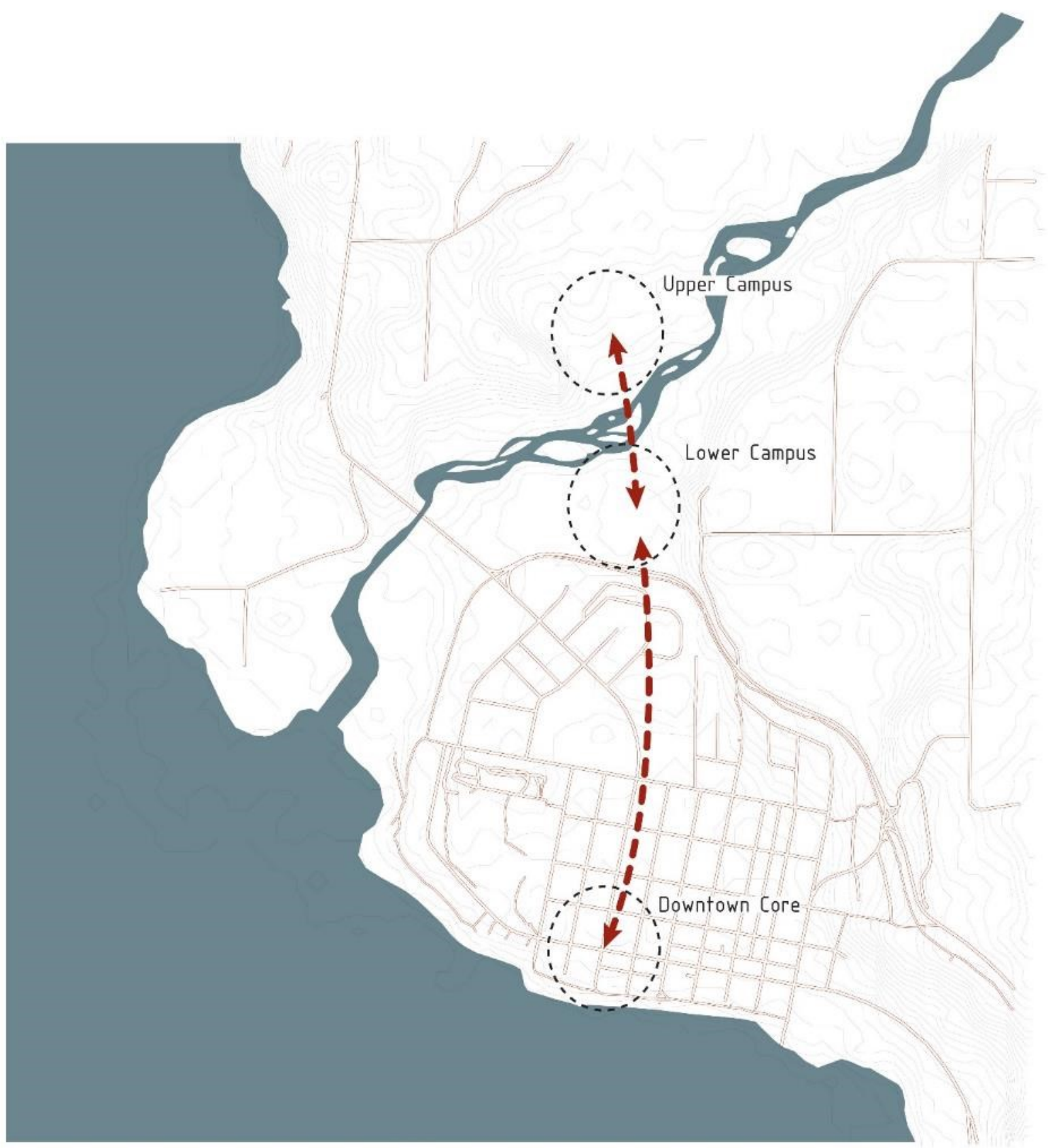

Fig. 33 - Urban Plan - Phase 1 
UPPER CAMPUS

As noted above, the Upper Campus differs from the Lower Campus in the kinds of ргоgrams and facilities it accommodates. In addition to the trade-oriented and wood-productsdevelopment ргоgrams, student residences will be located on the Upper Campus (see fig. 33). These residences - which will be constructed as enrolment expands - are envisioned as the norther terminus to the proposed north/south multi-use path.

Placing the trades campus to the north of the creek also provides more elbow room for facilities in the Lower Campus, whose expansion is constrained by the сгеek, highway, and the escarpment to the east.

\section{LOWER CAMPUS}

The Lower Campus will host the majority of the buildings associated with the educational institution. These include a cultural centre, classroom buildings, a mixed-use commercial/residential street, and a boutique hotel with a high-profile restaurant. The hotel, operated by the hospitality program, acts as a pedagogical tool attracting serving visitors to the site. Locating these more public amenities in the Lower Campus makes them accessible to the larger community. While this seems to run counter to the municipal documents restricting development along Highway 6 (see fig. 26), there will be no direct frontage onto the highway and vehicular access to the campus will be limited to a new road and signalized intersection at $10^{\text {th }}$ Ave. Limiting access from the highway will reinforce the importance of the north/south multi-use path, which crosses the highway just to the east and connects to the downtown core. In addition, it is imperative that development north of Highway 6 have a minimal impact on current vehicular flows along Highway 6.

NORTH-SOUTH PATHWAY The North-South pathway links the Upper and Lower Campus Nodes with the downtown core. En route this pedestrian and cycling path crosses over and through a variety of different conditions, each of which is concieved of as an event or point of interest (see 
fig. 36). The first of these is a bridge over the Kuskunax Creek, connecting the upper and lower campuses. Given the span of approximately 100 meters, this is as an opportunity to сгеate an iconic structure that can be used for town branding and cultural identity. 


\section{4 - PHASE 2}

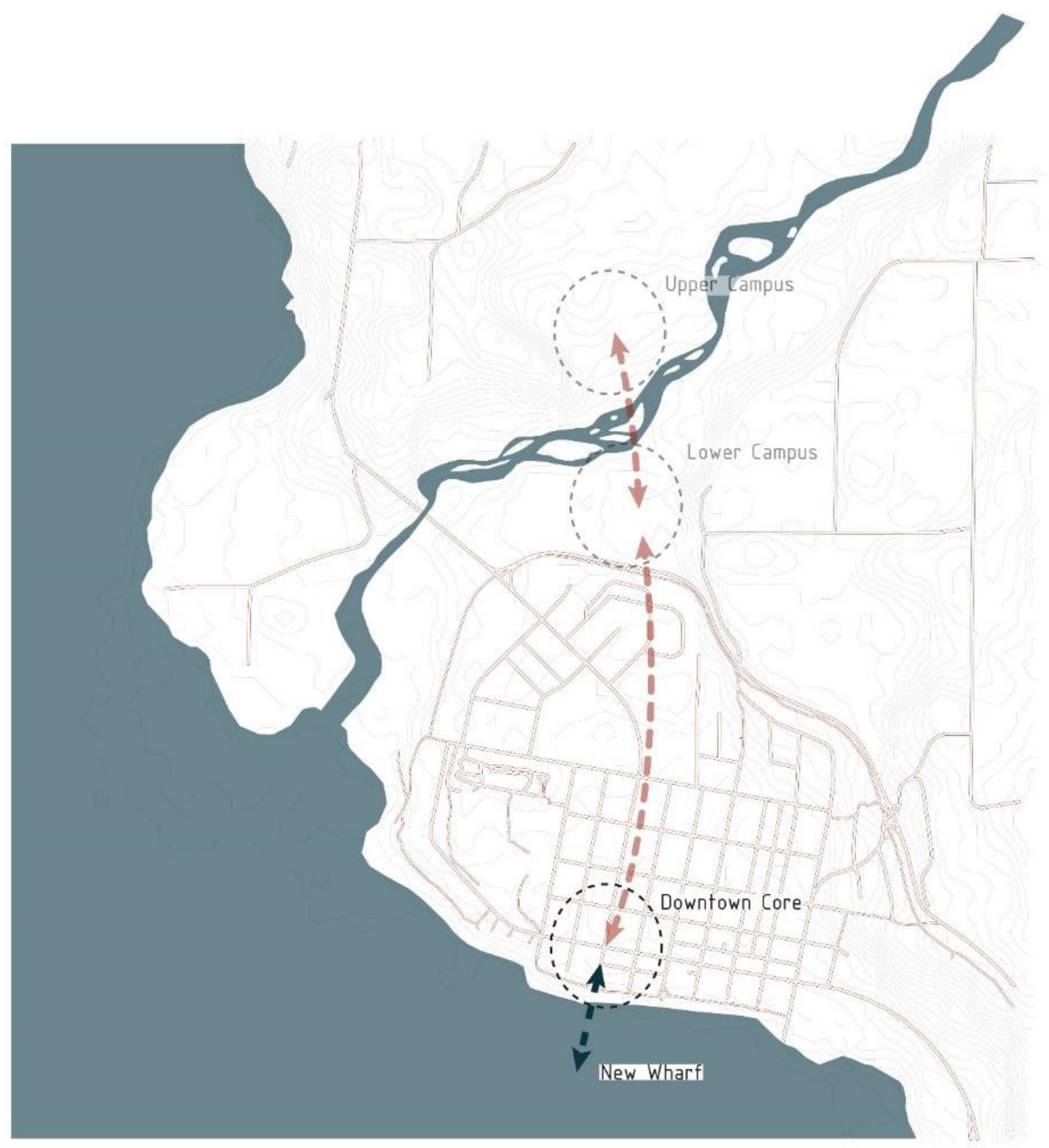

Fig. 34 - Urban Plan - Phase 2 
WATERFRONT PIER

Phase Two will consist of an extension of the circulation path through the downtown core to the Lakefront (see fig. 34). It will terminate at a new public pier designed to enable the community to better engage with its historic waterfront. Among other things the ріег is a mechanism to reclaim a portion of the waterfront lost to the flooding of the Аггоw Lakes as seen in figures 8 \& 9. It will also supplement the existing public wharf to the east. Markers along the wharf could indicate to pedestrians the position of the original waterfront prior to the construction of the dams. 


\section{5 - PHASE 3}

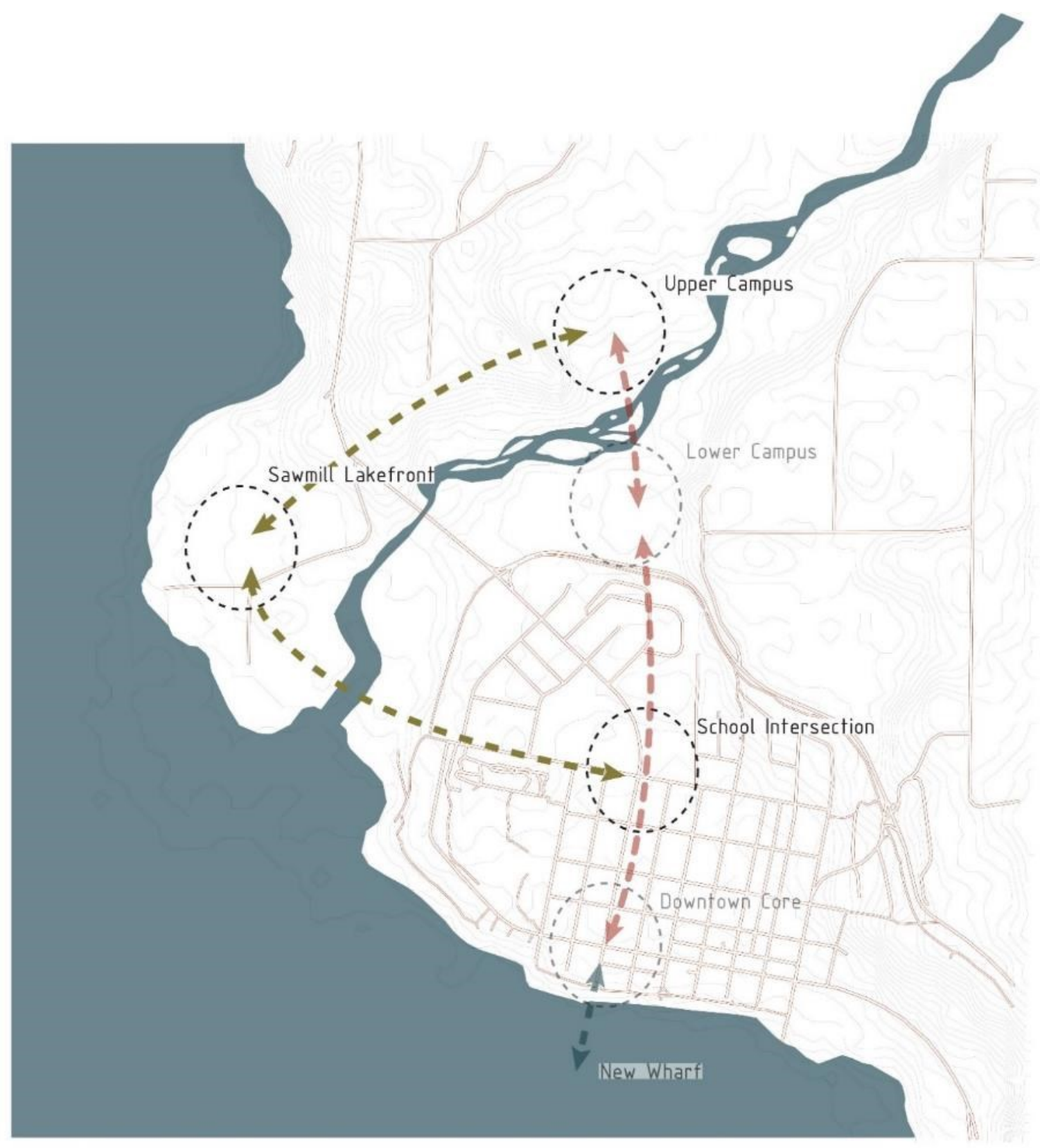

Fig. 35 - Urban Plan - Phase 3 
SAWMILL-LAKEFRONT

In phase three, the derelict industrial land along the lake waterfront will be transformed into a new residential district. This new neighborhood will include a lakeside promenade, taking its cues from precedents like Seaside, Florida (see fig. 19). Multiple access points to the promenade will be provided through the neighborhood. While properties nearest the waterfront will benefit from the best views, the waterfront will remain accessible to everyone.

A multi-use pathway and bridge across the Kuskunax Сreek will connect the SawmillLakefront with the North-South Pathway at the School Intersection. This path will resemble the Whistler Valley Trail shown in Figure 21. Spanning the creek delta, this path will cater exclusively to pedestrians and bikes - at least in the short term. It would encourage people to choose active modes of transportation rather than driving into town.

The pathway connecting the Sawmill-Lakefront to the Upper Campus will make use of existing trail along the north side of the Kuskunax creek. Working in concert with the other paths, it will complete a circular circuit and act as a potential recreational activity for visitors and locals alike. 


\section{6 - LOWER CAMPUS AND PATHWAY DETAILING}

While the master plan for the town consists of multiple nodes to accommodate new рrogrammatic elements, the Lower Campus and North/South Pathway have been chosen for further development. Together these components act as anchors for the phases that follow. The Lower Campus is the most important node, as it contains the many of the new ргоgrams that will benefit the town: the cultural \& гесгеation centre, the hotel, and most of the academic buildings.

The North/South pathway is a key to the success of the overall masterplan. Without it, the different programmatic elements become a series of isolated projects rather than a connected network. The pathway envisioned as the new backbone of the town, the armature to which everything connects. 
Street Furniture

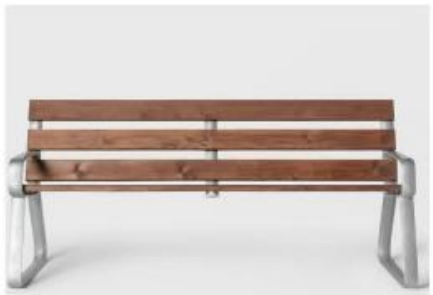

(1) - Bench

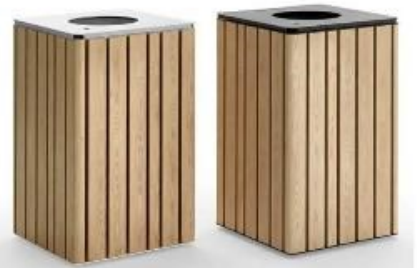

(2) - Litter Bin

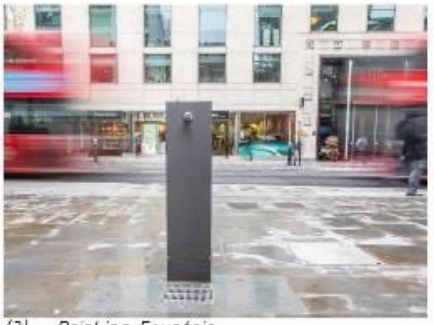

(3) - Orinking Fountain

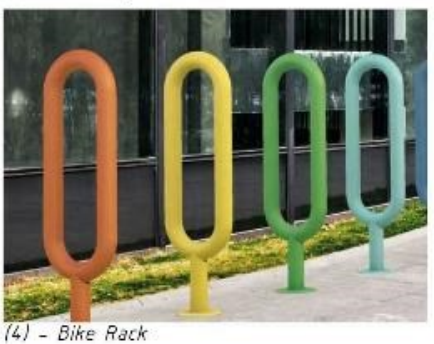

Materials

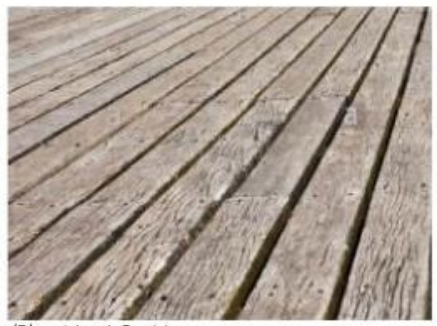

(5) - Wood Decking

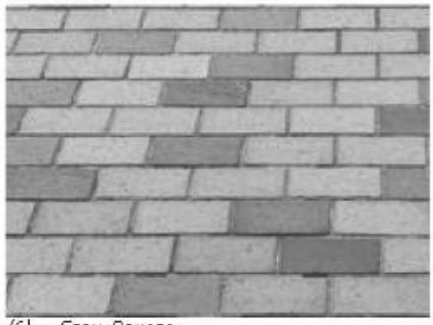

(6) - Gray Pavers

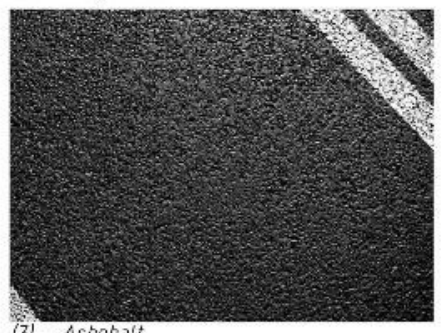

(7) - Ashphalt

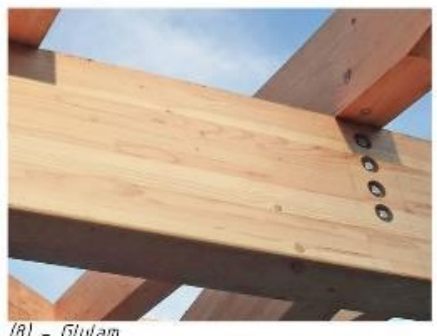

(8) - Giviam
Plantings

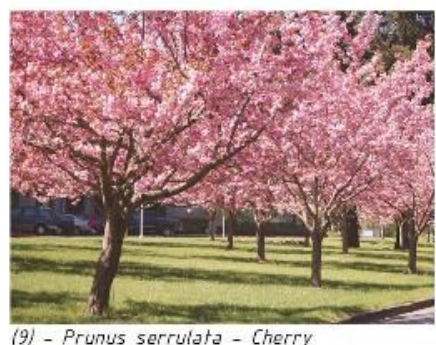

(52.

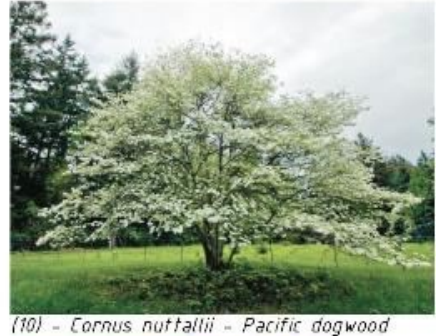

(10) - Cornus nutfallii - Pacific dogwood

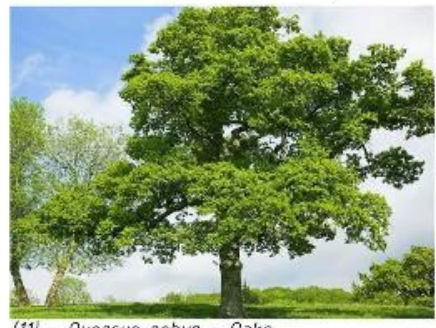

(11) - Quercus rabur - Oaks
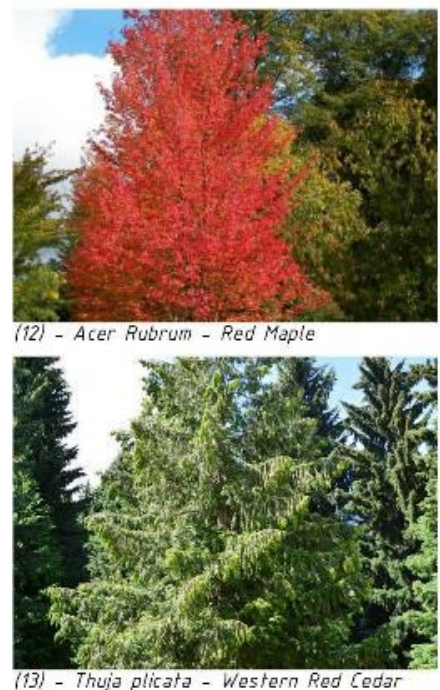

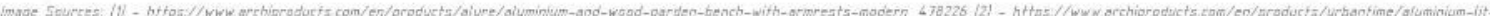

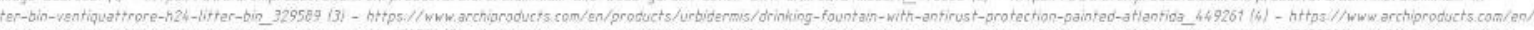

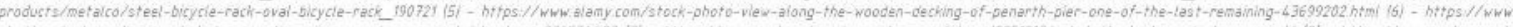

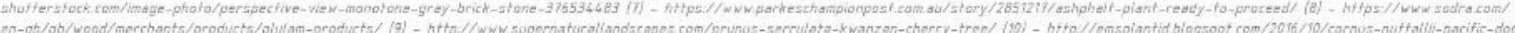

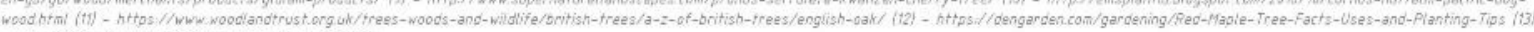

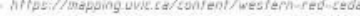

Fig. 36 - Pathway Materiality 


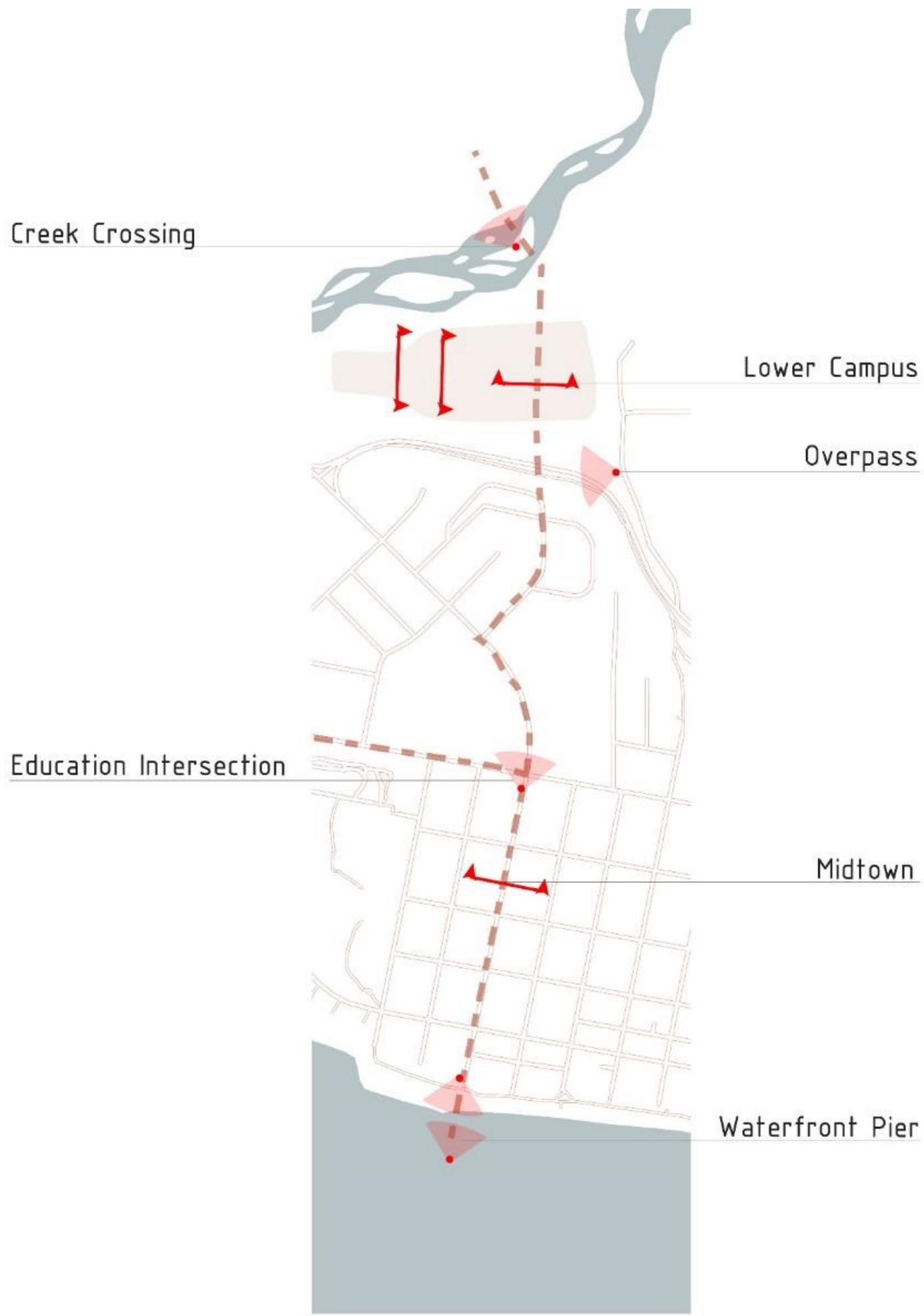

Fig. 37 - Proposal Detailing - Key Map 


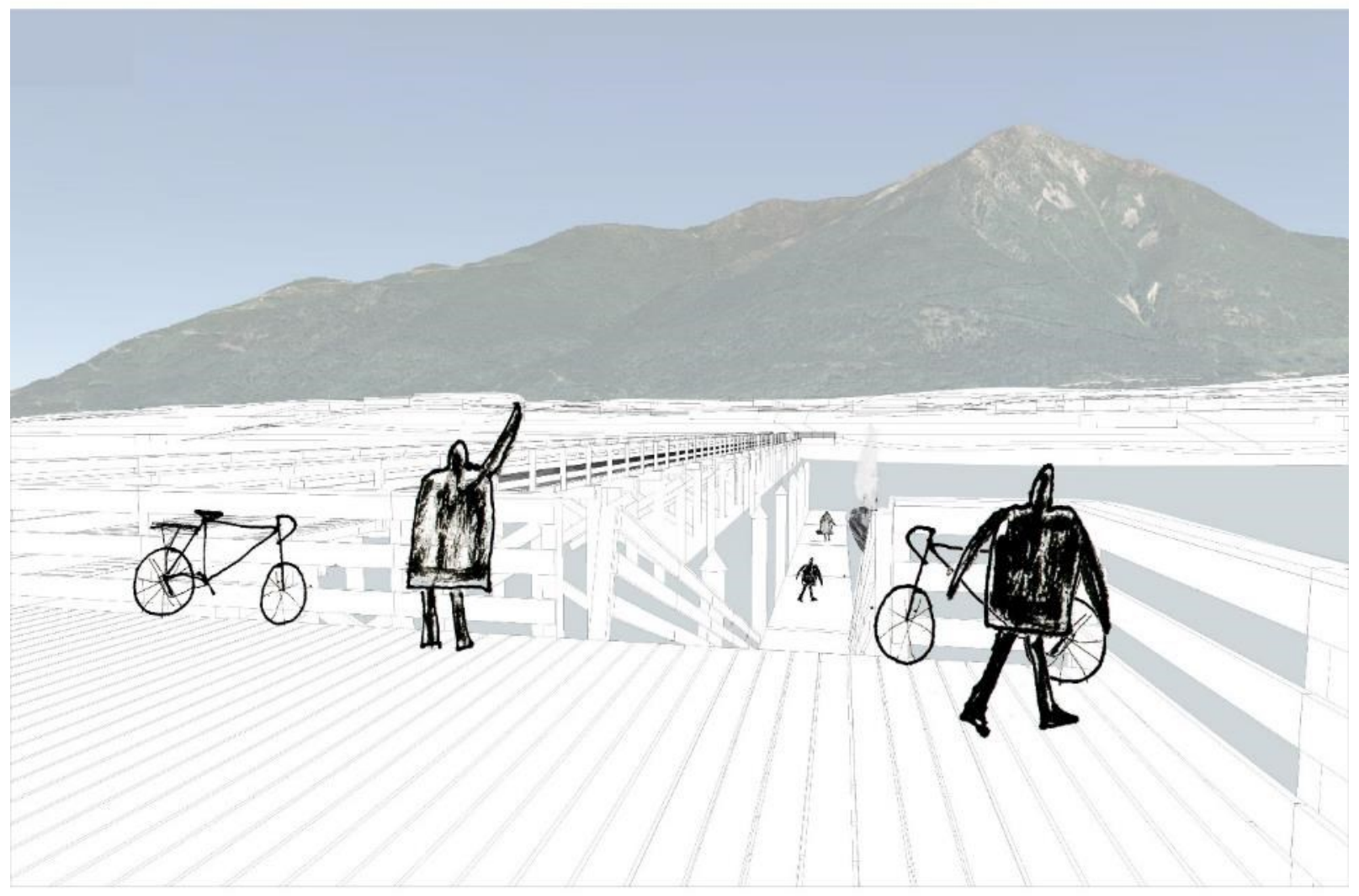

Fig. 38 - Vignette - End of Pier 


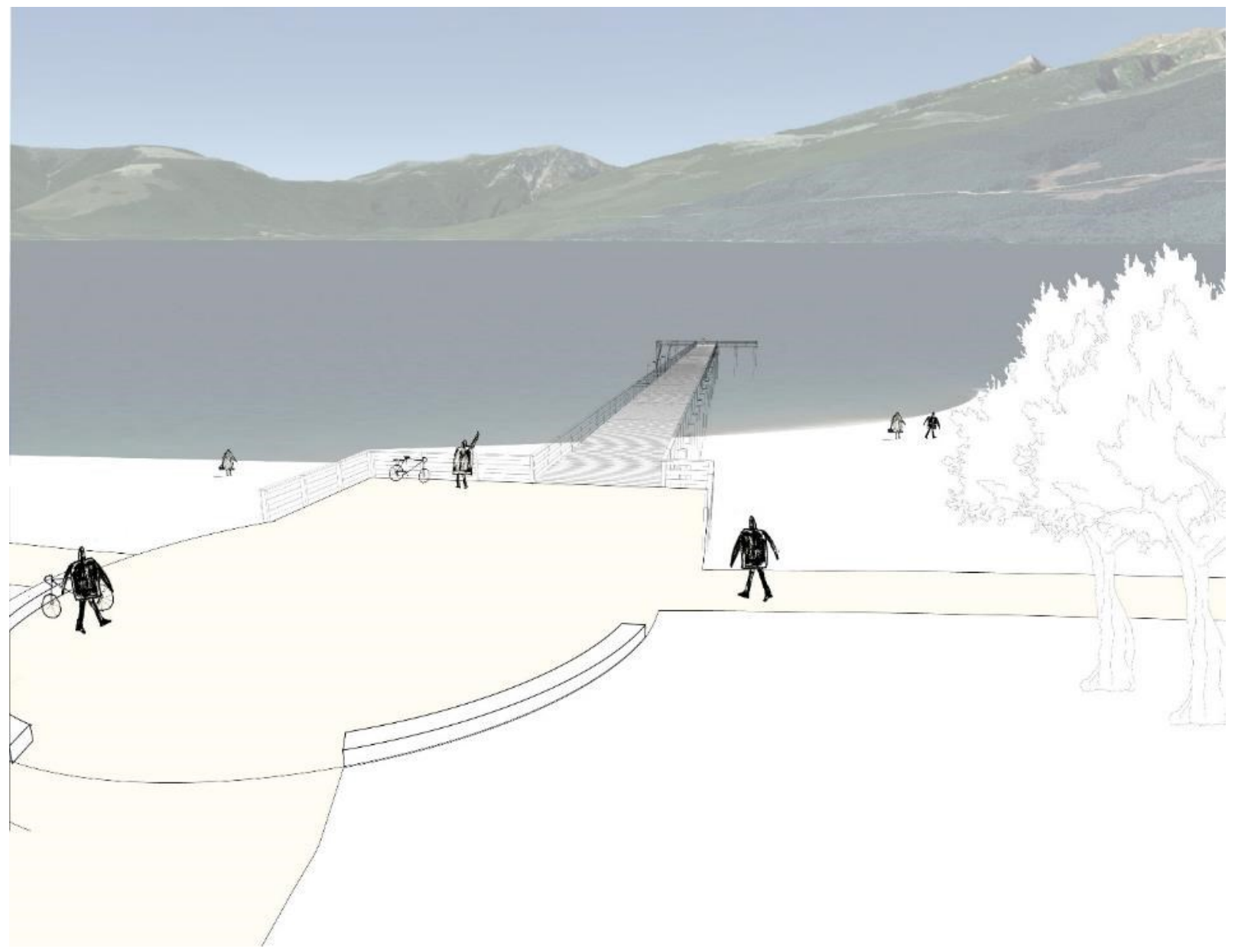

Fig. 39 - Vignette - End of 6th Street 


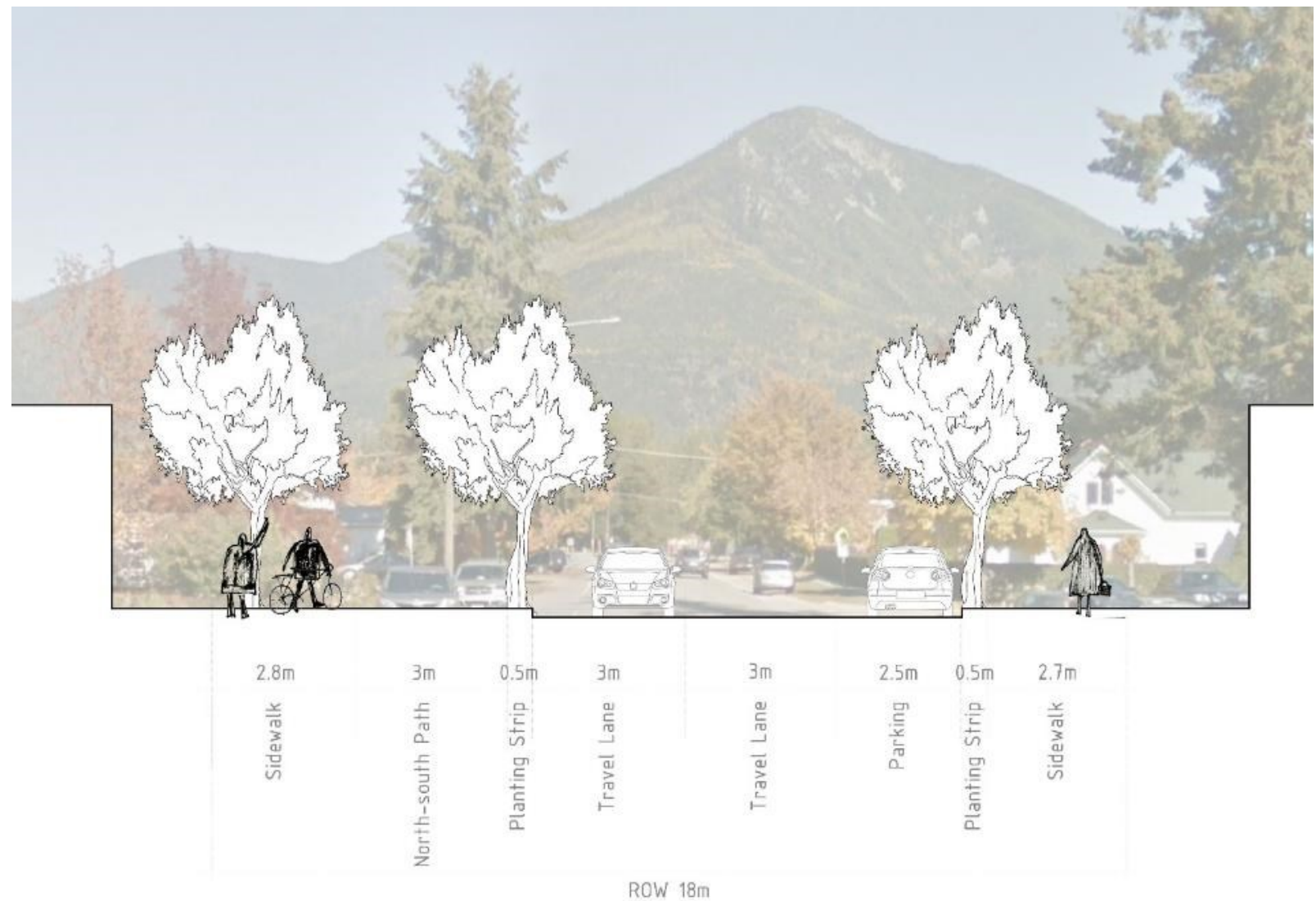

Fig. 40 - Section - Midtown - the North-South Path along 6 th St. 


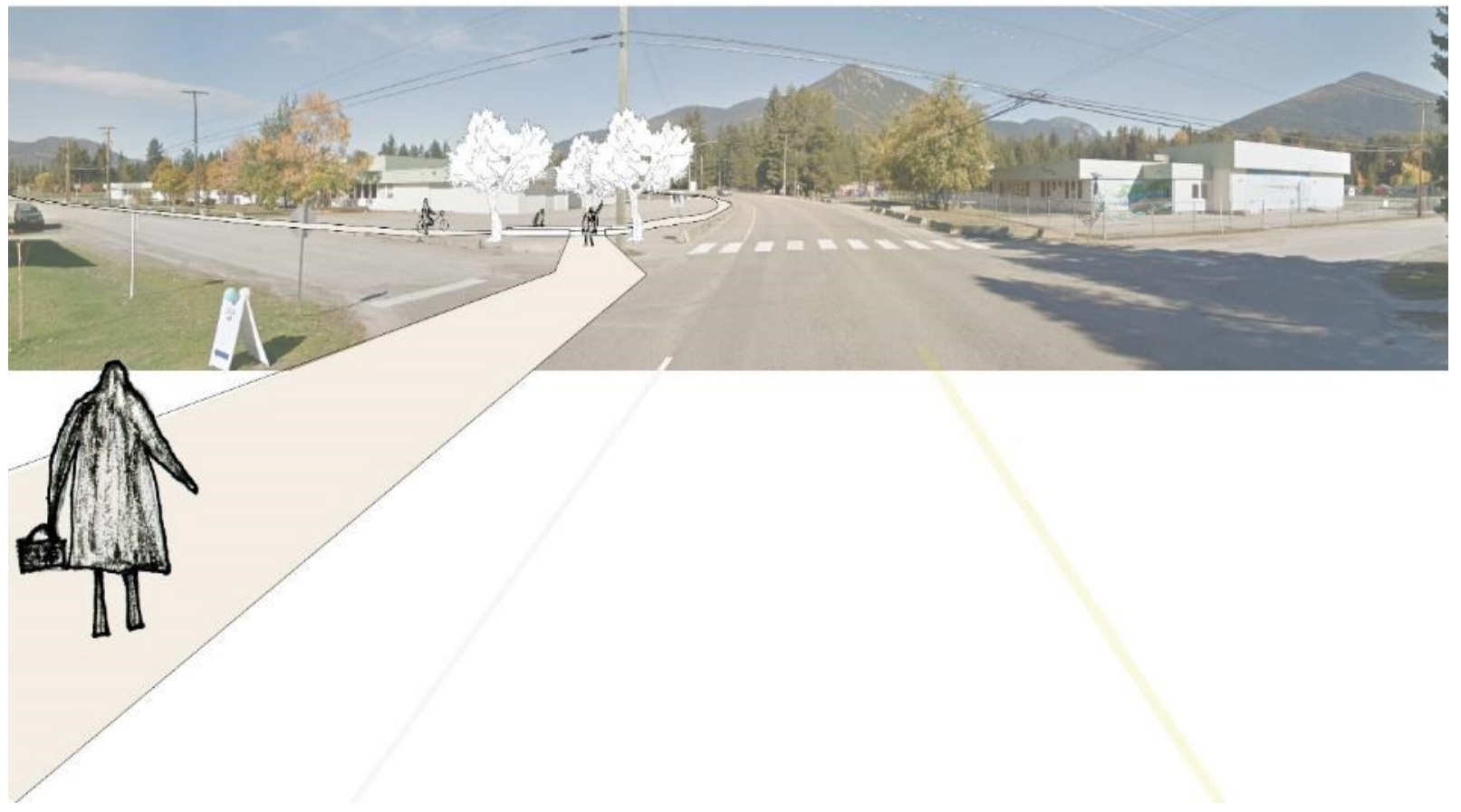

Fig. 41 - Vignette - the meeting of the North-South and SawmillLakefront paths at the School Intersection 


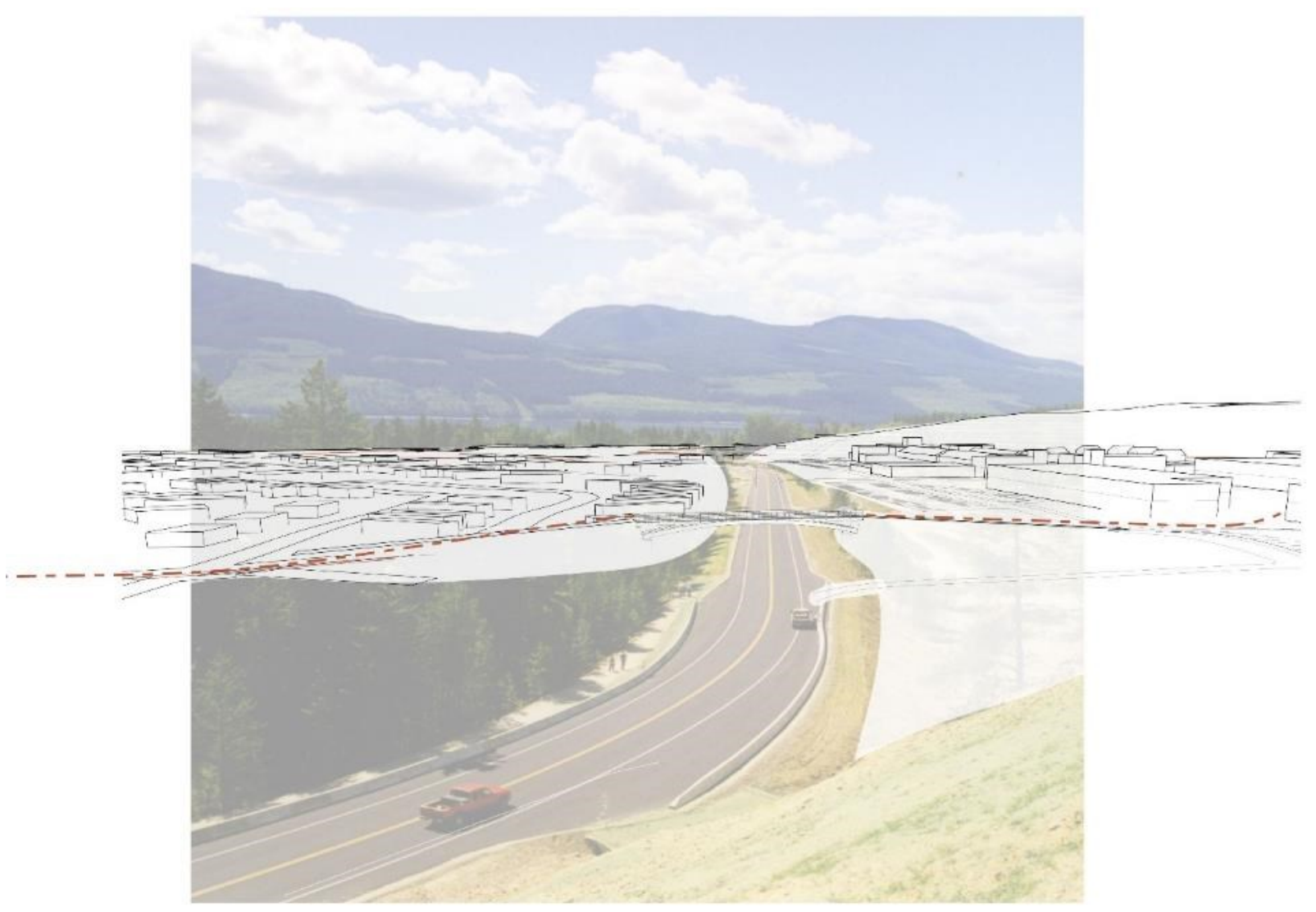

Fig. 42 - Vignette - Overpass -- the North-South path crossing Highway 


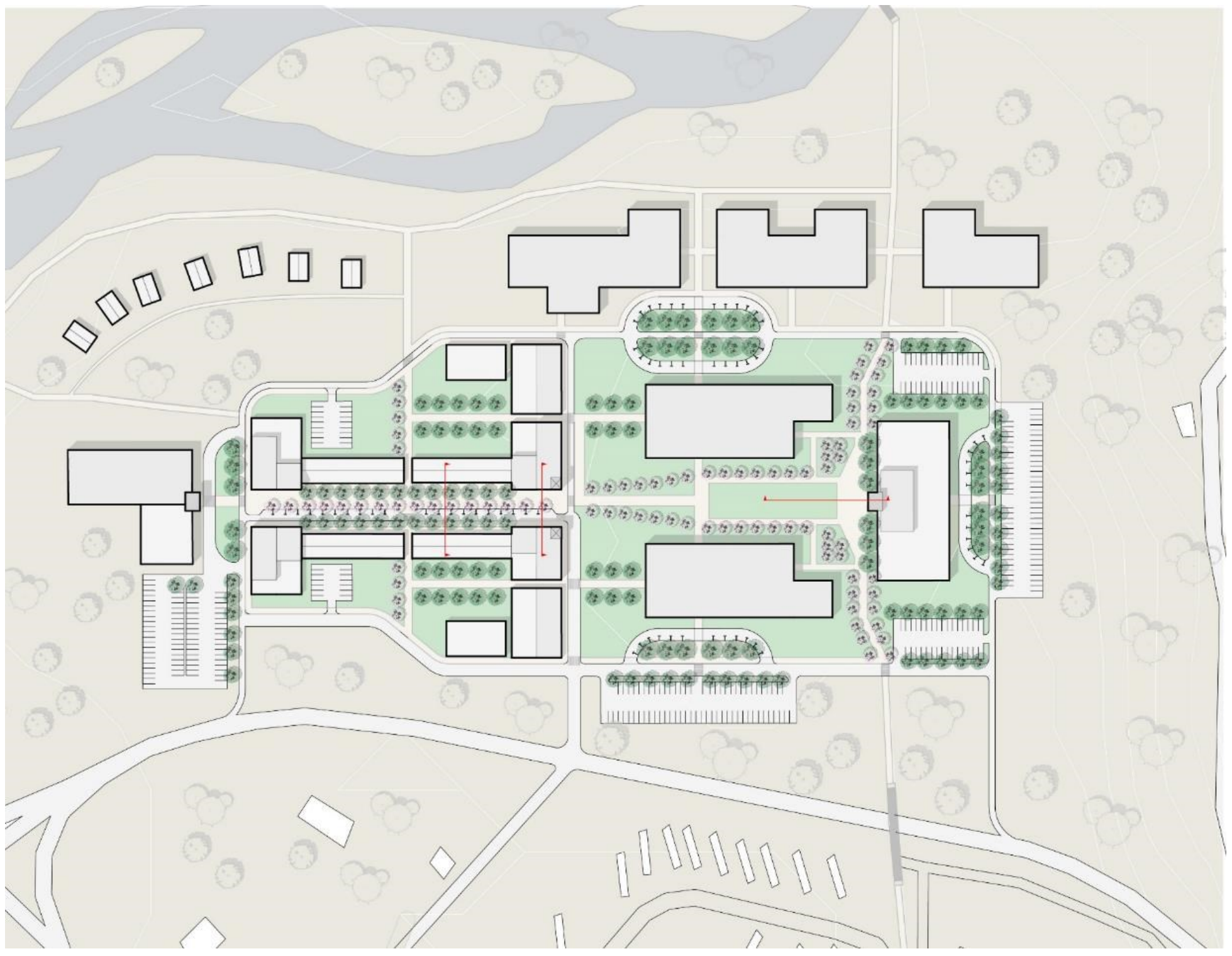




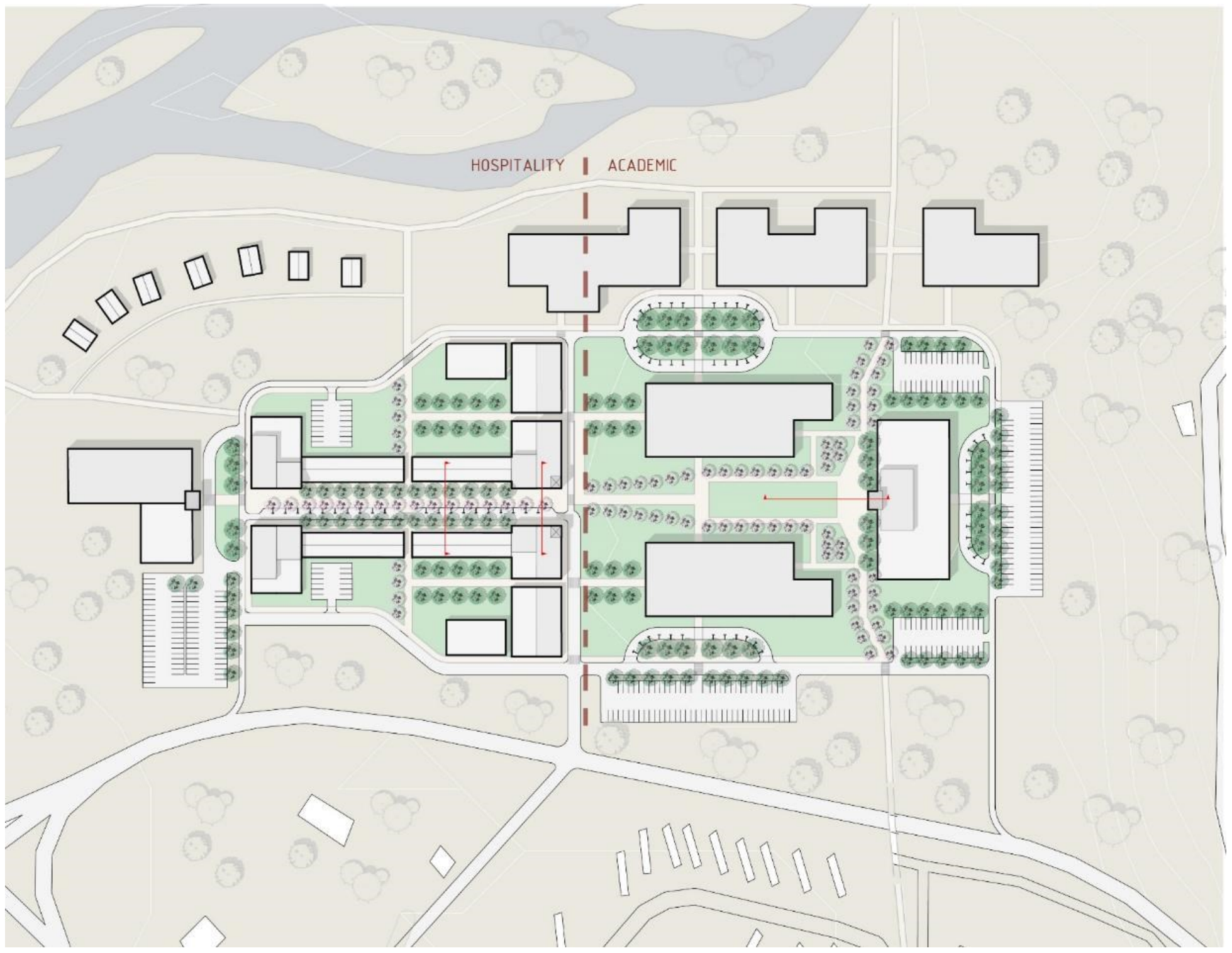




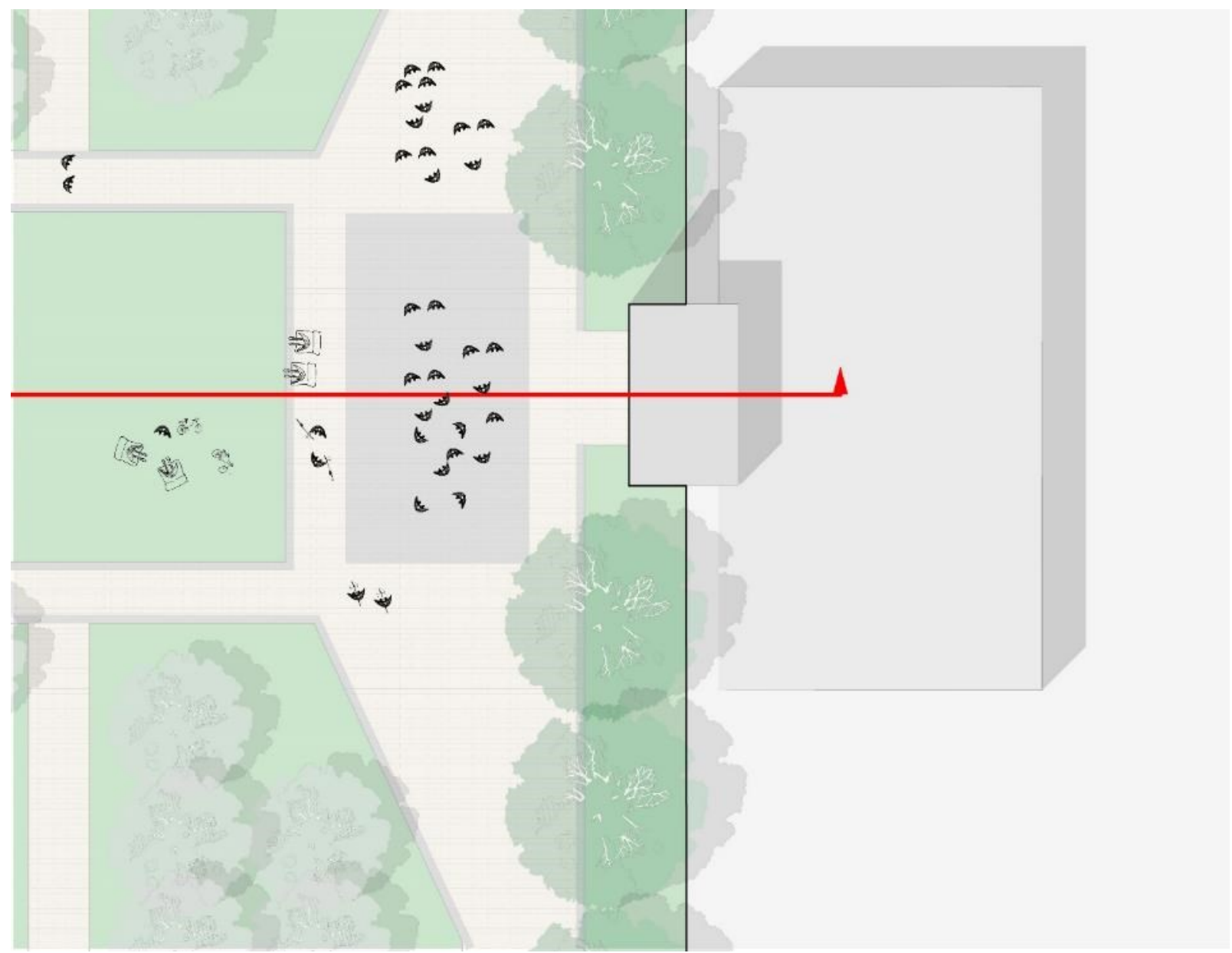

Fig. 45 - Detail Plan - Recreation Plaza 


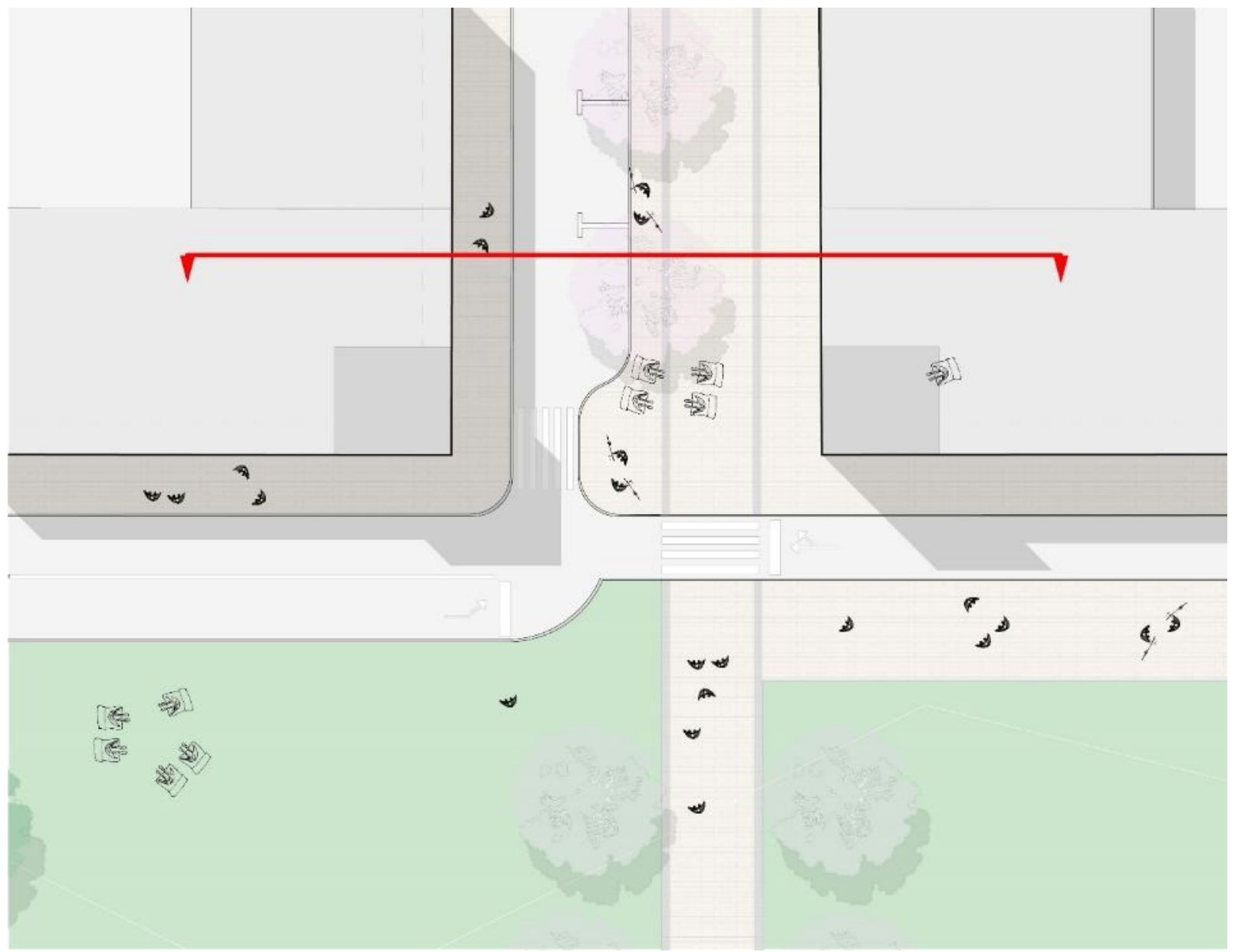

Fig. 46 - Detail Plan - End of Block 


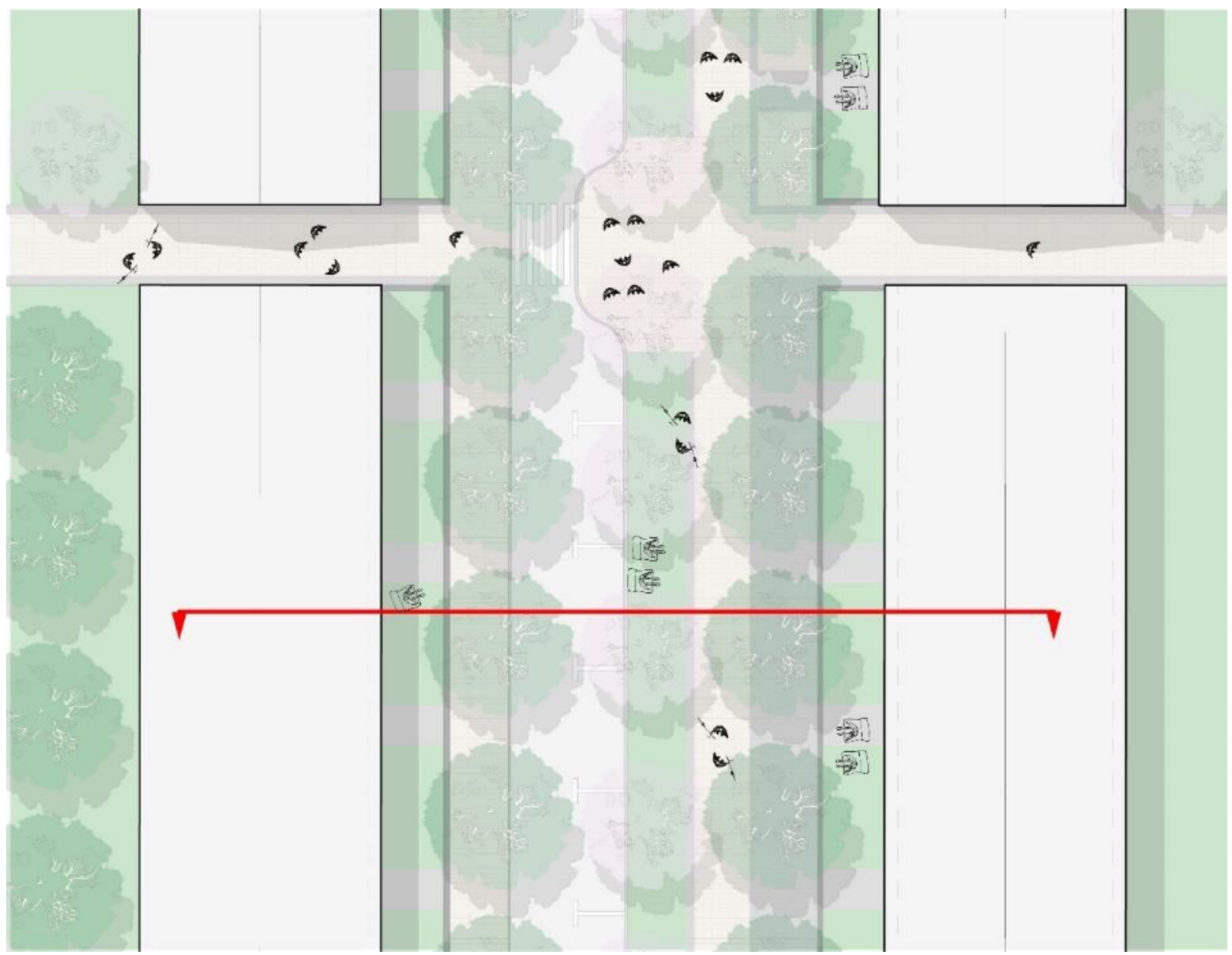

Fig. 47 - Detail Plan - Mid-Block 


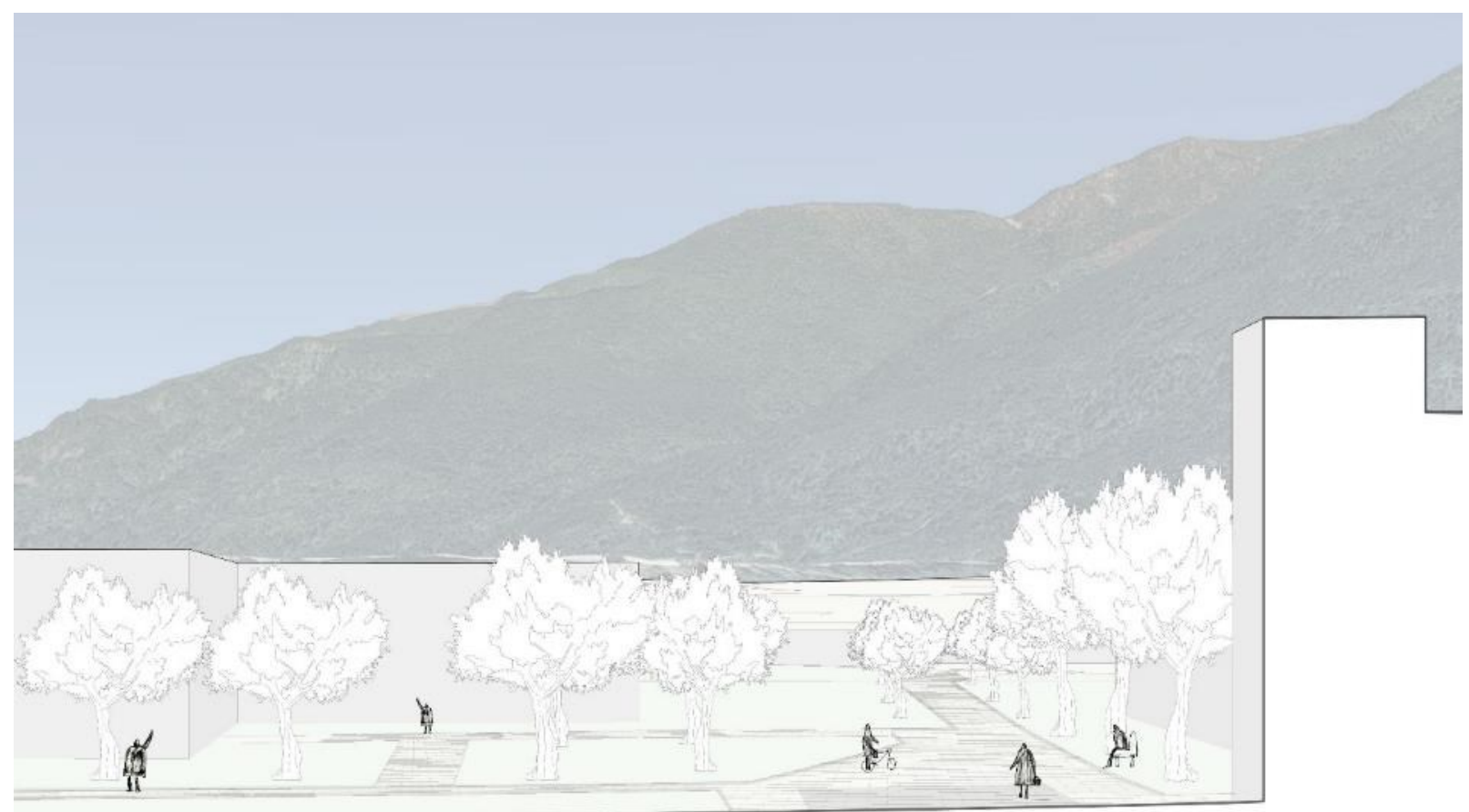

Fig. 48 - Section Perspective - Recreation Plaza 


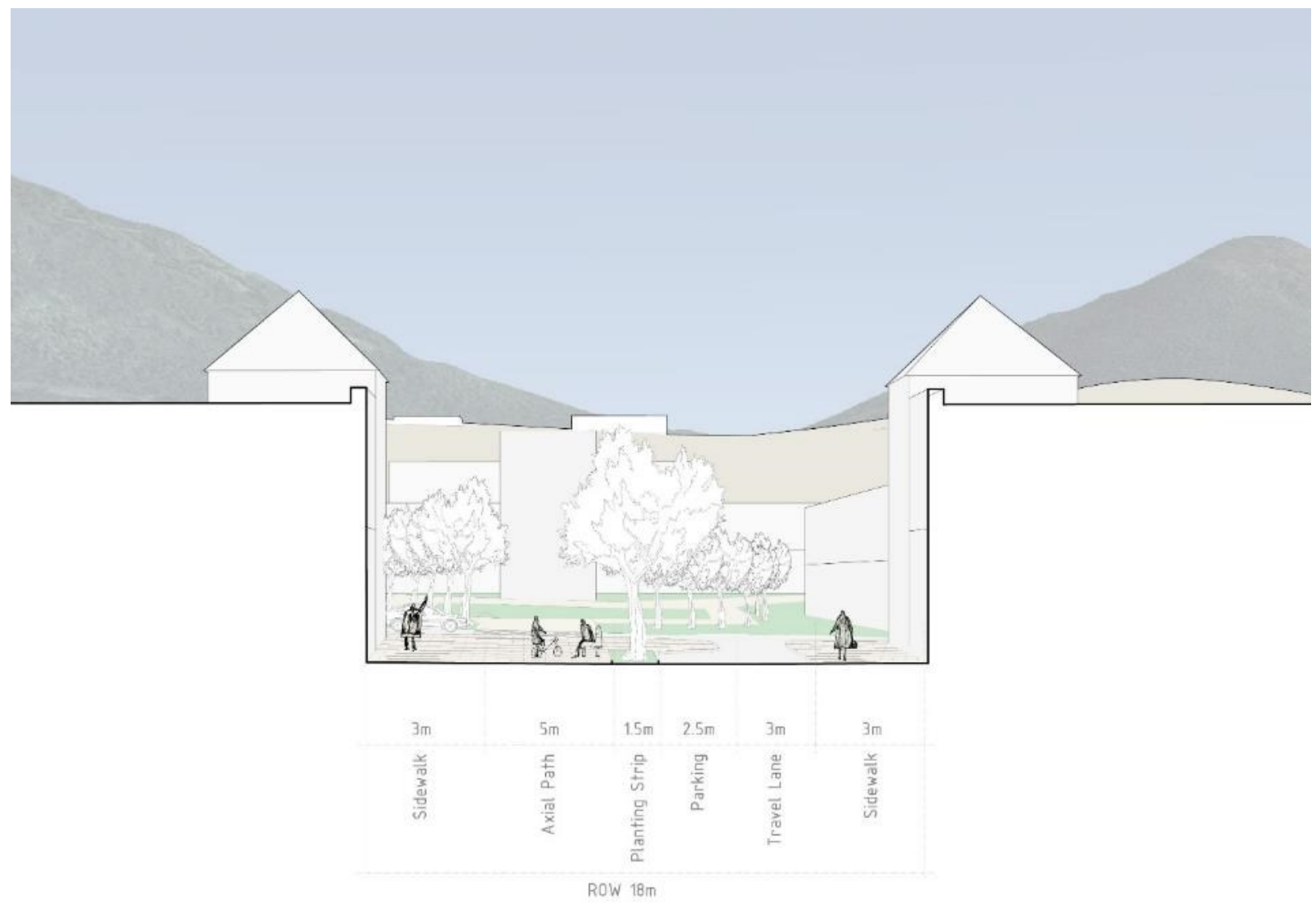

Fig. 49 - Section Perspective - End of Block 


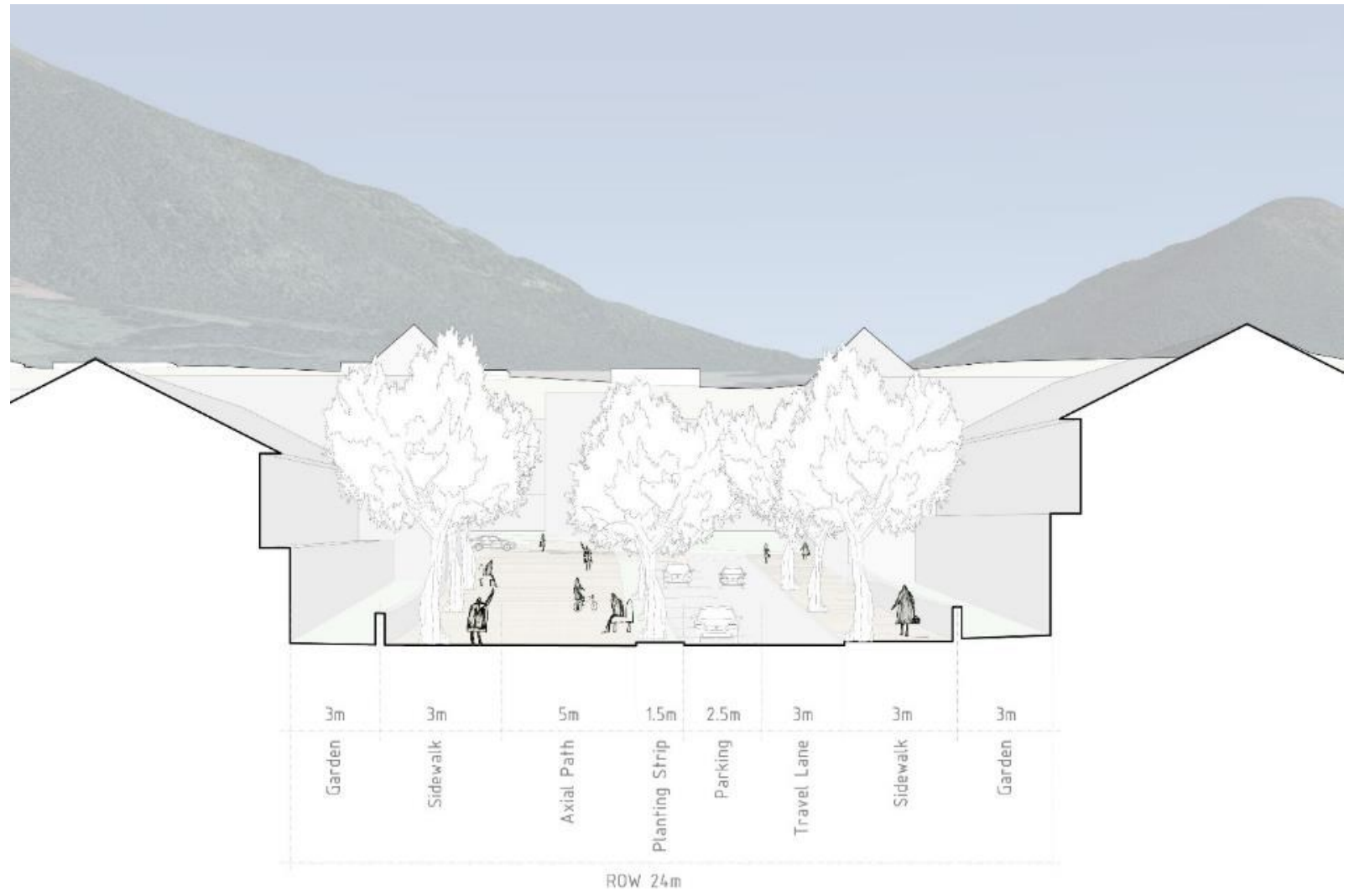

Fig. 50 - Section Perspective - Mid-Block 


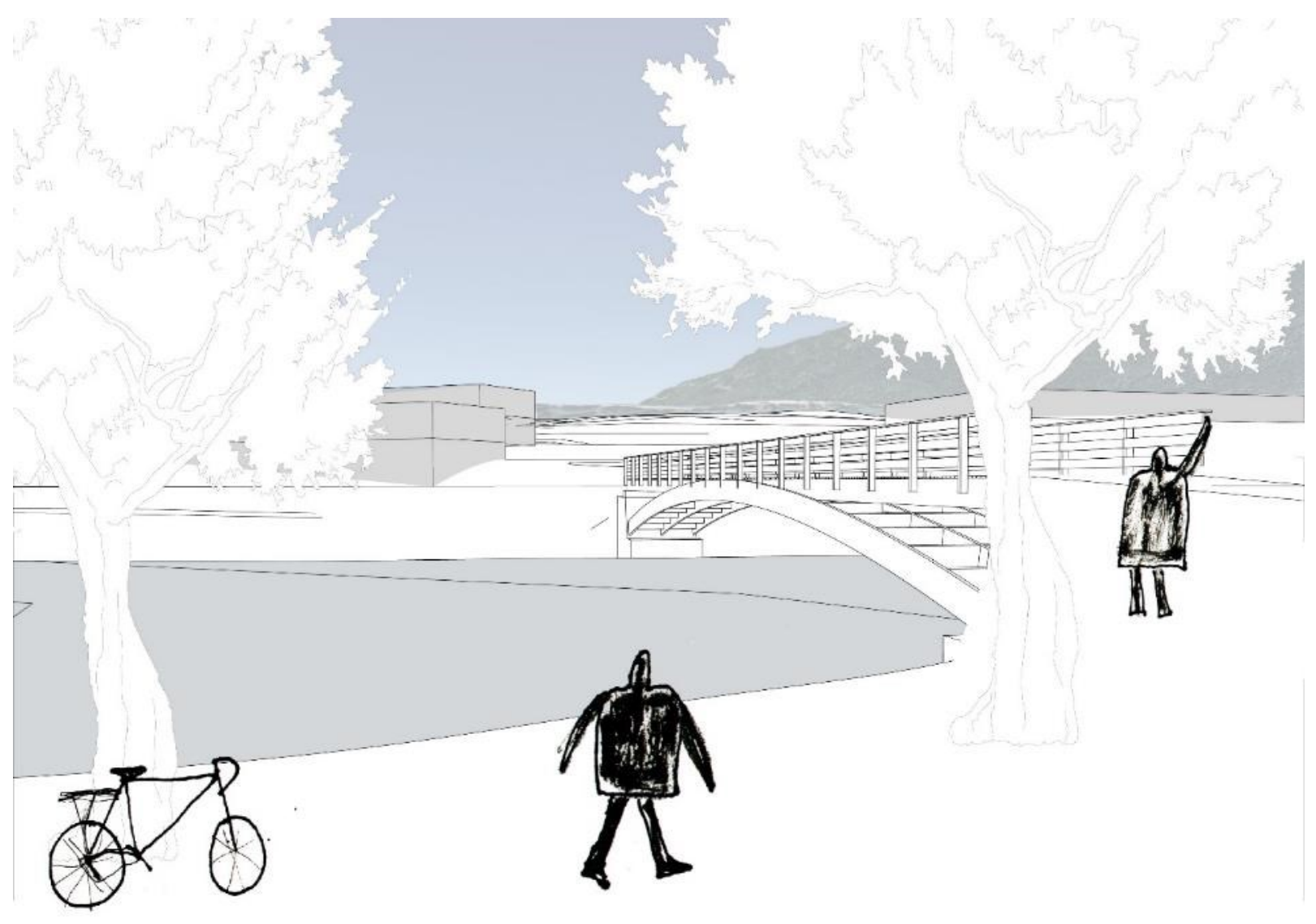

Fig. 51 - Vignette - Towards Upper Campus - bridge over Kuskunax Creek 


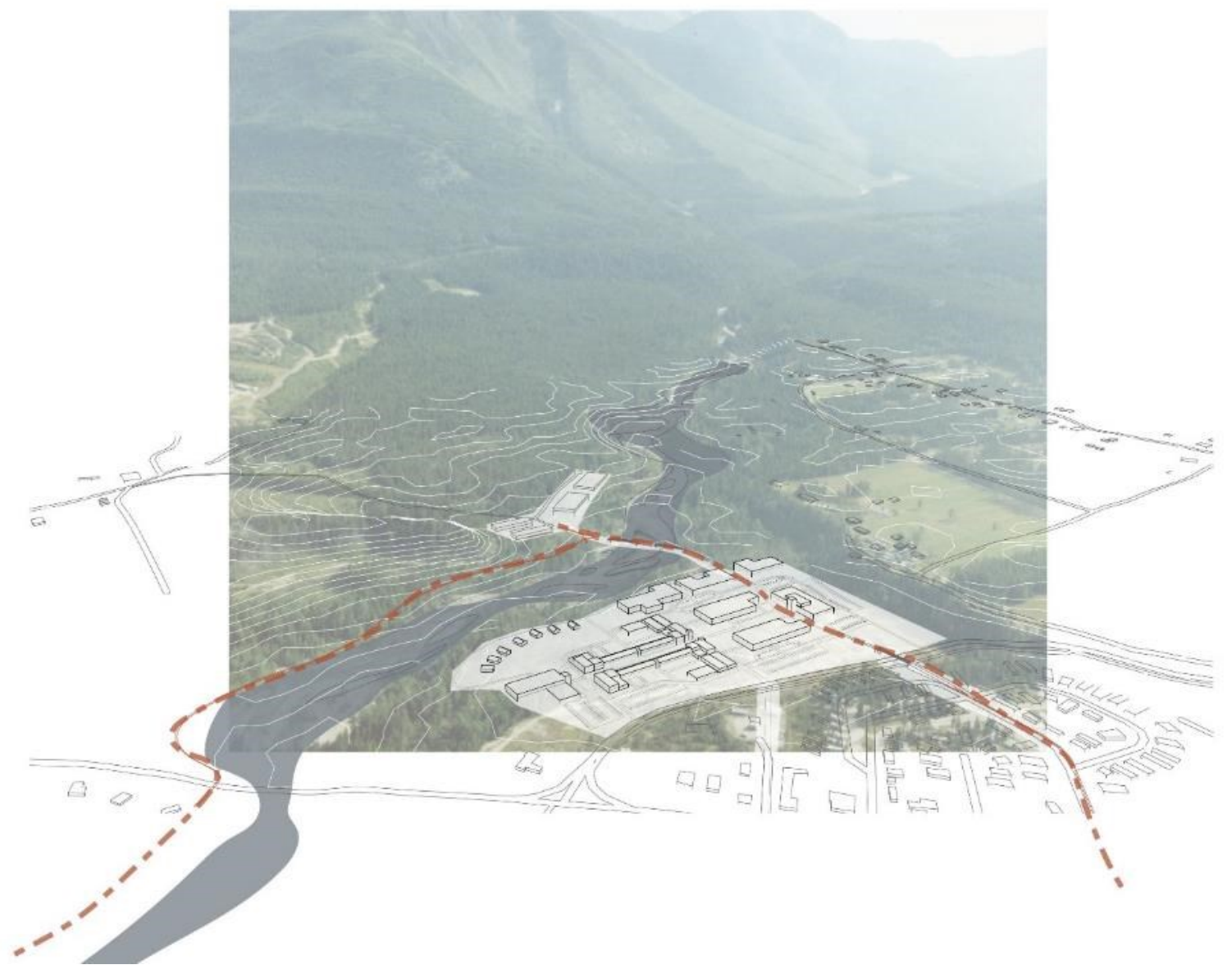

Fig. 52 - Perspective - Campus Aerial looking Northeast 


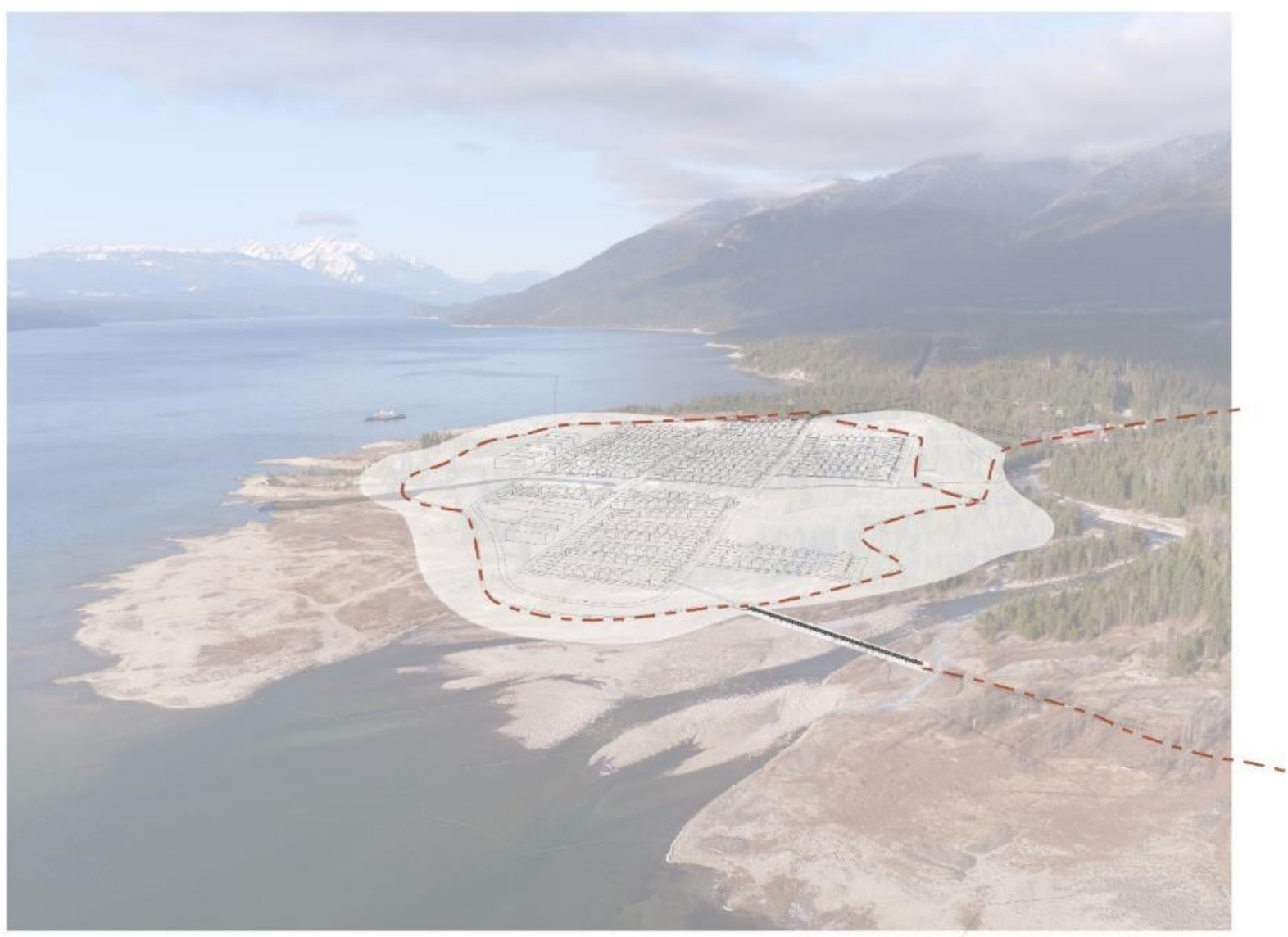

Fig. 53 - Perspective - Sawmill Lakefront Residential 


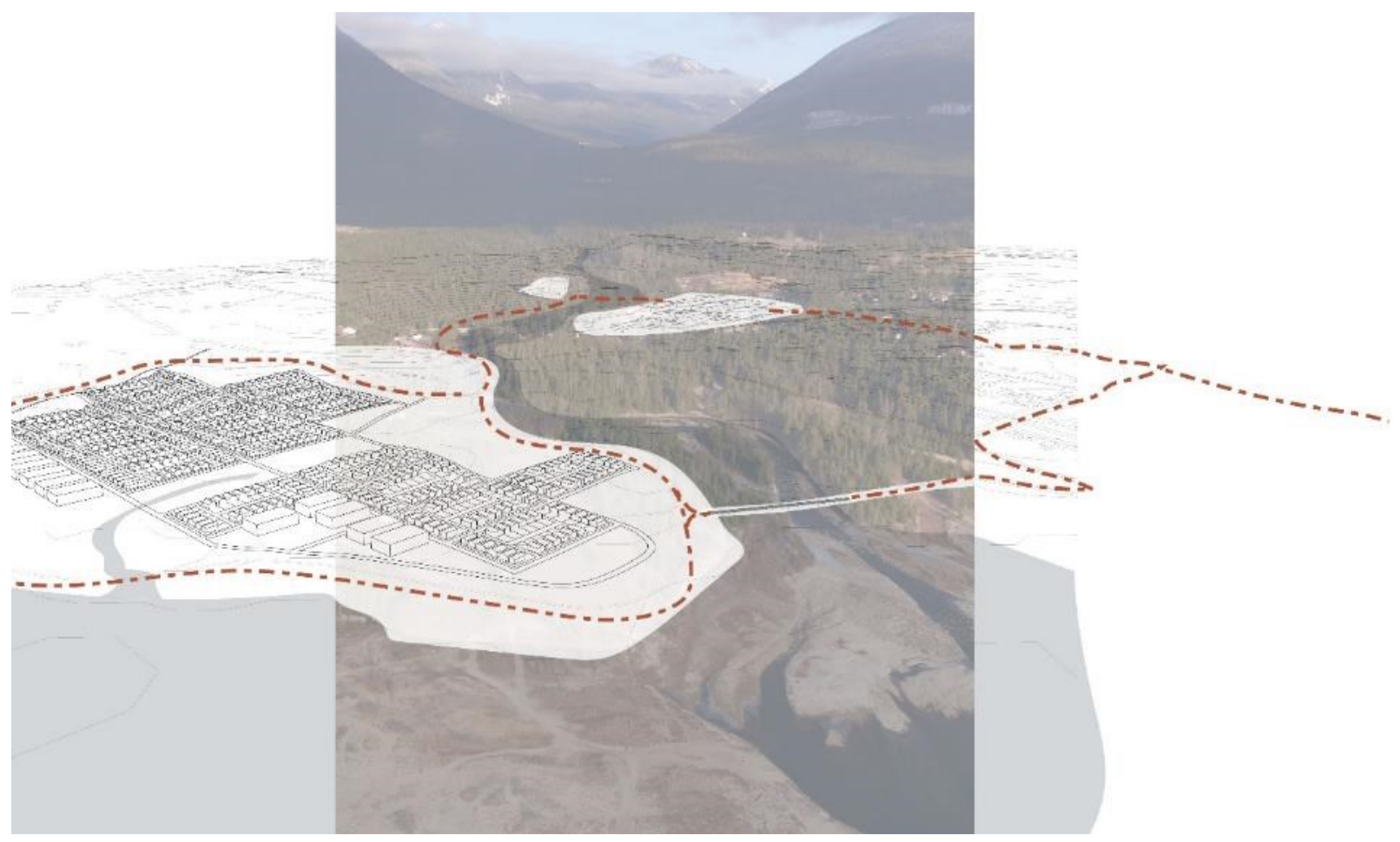

Fig. 54 - Perspective - Overall Network 
${ }_{55}$ Marc Schlossberg et al., "Rethinking Streets for Bikes An Evidence-Based Guide to 25 Focused Street Transformations" (University of Oregon, 2019),

https://nitc.trec.pdx.edu/research/project/1081/From_Knowledge_to_Practice:_Rethinking_Streets_for_Peo ple_on_Bikes.

${ }^{56}$ Village of Nakusp, "Zoning BYLAW-614-Consolidated-to-Jan-15-2019-614-24.Pdf," accessed October 8, 2020, http://nakusp.com/wp-content/uploads/2019/02/BYLAW-614-Consolidated-to-Jan-15-2019-614-24.pdf. 


\section{0 - CONCLUSIONS}

This thesis explores how resource-based communities might diversify their economies to better withstand the fluctuations of external markets. Heading into the project, I was biased towards a single 'drop-in' industry to address the short-term need for employment. Given Nakusp's longstanding ties to forestry, I envisioned a wood manufacturing facility to replace the ones the town had lost. Alternatively, I considered tourist infrastructure, building on the municipally owned hot springs complex, $14 \mathrm{~km}$ north of the town. Early on, however, it became аррагеnt that an "either/or" proposition was not workable, given the risks associated with depending on a single industry. Могеover, investing in the expansion of hot-spring complex risked drawing people away from the town itself. As such, it was better to bring key aspects of the hot springs to the town le.g., a resort hotel and restaurant - and a shuttle bus), rather than bringing the town to the hot springs.

Through a review of resource-based communities in British Columbia, a review of municipal planning documents, and an analysis of various ргеcedents, I determined that community resilience is closely tied with localized economic diversity. Building a network of localized dependencies is fundamental to the long-term sustainability of a community.

In researching the Arrow Lakes region, I also realized the extent to which resource extraction and hydroelectric projects, while key to the economic development of the region, may have benefited distant metropolitan агеas more than the region itself -- especially given exit of major industries from towns like Nakusp.

The ргoposed master plan for Nakusp provides the community with strategies to decrease their dependance on resource extraction and leverage new opportunities. It is intended as a vision of how the community might restructure itself, both physically and economically. What I'm proposing as tourist infrastructure and new facilities for value-added wood manufacturing аге tied together through the post-secondary institution, which offers рrograms in wood engineering and hospitality. All three elements come together on the campus, which is tied to and through the town by the North/South Pathway. The new 
residential district connects to this pathway with the westward extension of $4^{\text {th }}$ St., which, like the North/South path, is envisioned as a multi-use path along a causeway crossing the delta of the Kuskunax Сreek. This path, in turn, connects into the new lakefront promenade described above. Rather than using their cars, students from the campus and residents of the new residential district - including the retirees who will be attracted by the tourist and cultural infrastructure associated with the Nakusp's new post-secondary institution (геtirees love university towns) - travel in and out of downtown on foot or by bicycle. The intersection of the east/west and north/south MUPs is envisioned as a major node - one of a number along the North/South pathway.

New employment opportunities in an educational institution will draw new residents to the community, including the retirees referenced above. Facilities that serve students аге open to the town at large, supplementing existing facilities. The ргеsence of a post-secondary education in Nakusp may also increase youth retention in the community and provide a local source of inspiration to continue schooling. The North/South circulation pathway, which both parallels and connects into the town's existing circulation network, is the physical manifestation of the urban plan network. The new residential district along the lakefront to the west will address the need for additional housing as the population expands.

Among the issues that are beyond the scope of the design proposal, however, is the issue of redressing the significant amount of land lost to the reservoir with the construction of the hydroelectric dams. The benefits of these large infrastructure projects have largely felt by distant metropolitan centres.

This leads to another question regarding the role of architects and designers in considering how and by whom land is used. In the course of my research into the flooding of the Аггоw Lakes, I uncovered a violent tendency to disregard the presence of Indigenous people. Nakusp has direct roots to the Sinixt nation (the name, Nakusp, derives from a Sinixt word), and the descendants of the original Indigenous inhabitants will live in the region. In spite of this, however, Canadian administrative jurisdictions list this nation as 
extinct. ${ }^{57}$ When confronted with this invisible history, how can architects, designers, and other professions make room for an Indigenous resurgence?

Some of the next steps for this proposal is to present it to the community as a platform for discussion. As this project acts as a vision for the future, community input would allow for further refinement of ideas into a built form. Components in the project - such as the Sawmill-Lakefront residential агеa - need a detailed masterplan before presenting to the community.

\subsection{FINAL CONSIDERATIONS}

One of the key concerns raised at the thesis defense was the distance between project elements. As is apparent in Figure 24, many of the proposed elements аге located on the periphery of the existing community. As this master plan proposes active transportation pathways to connect these newly developed areas with the existing соге, walking distances could be considerable. In addition to its location, concerns wеге also raised about scale of the proposed campus in relation to the existing community.

Early on I made the decision to propose what amounts to a stand-alone campus. In so doing I understood that I was also setting myself the challenge of knitting it back into the community. By siting the campus on the vacant, formerly industrial land between Highway 6 and the Kuskunax Creek I was able to avoid being restricted by existing fabric and to made provisions for the future expansion of both the town and the institution. While the campus master plan includes numerous buildings, I've гергеsented the institution as it might be in the distant future. Initially the campus would be comprised of only three buildings: the геcreation/cultural center, the hotel/hospitality center and the woodproducts facility. The design of each of these buildings would accommodate classroom space that could be converted to other uses if and as classroom buildings are constructed. This could, perhaps, be clarified with a phasing diagram for the build-out of the campus, the design for which accommodates many unknowns. 
Rather than competing with or sapping energy from the existing centre, the quasiperipheral location incentivizes locals to invest in the upgrading and intensification of underutilized land in the downtown core. With the influx of students and tourists, locals аге likely to assume an entrepreneurial posture, further strengthening the existing town. A new campus, adjacent to the existing community fabric could act as a catalyst point for further town improvement by not occupying land that could be used for other purposes.

A solution to these concerns is to insert some of the project elements into the existing town fabric. As seen in Figure 55, the dashed red lines indicate potential in-town locations for educational buildings. The two sites to the left of $6^{\text {th }}$ Ave. make use of undeveloped municipal land сигrently being used as a park, while the site to the right takes over an entire block that is currently used by the Ministry of Forests. This siting strategy for the campus puts the educational buildings close to existing municipal гесгеation facilities within the downtown соге, better integrating the institution into the community fabric. 


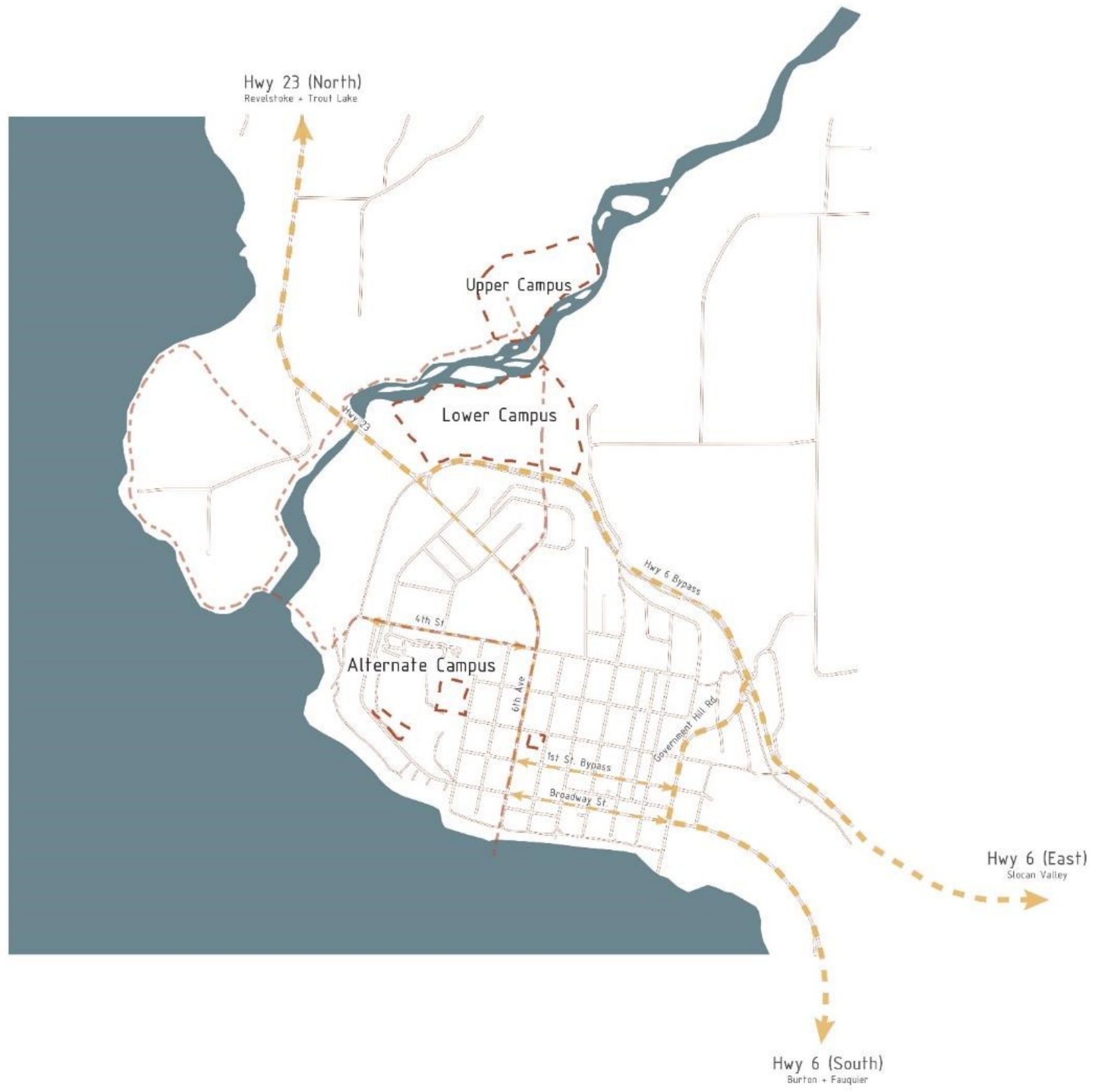

Fig. 55 - Site Selection - Alternate, "in-town" Campus Locations 
57 Paula Рryce, Keeping the Lakes' Way, accessed March 11, 2021, https://books-scholarsportalinfo.proxy.libгагу.carleton.ca/en/read?id=/ebooks/ebooks0/gibson_crkn/2009-12-01/6/417956. 


\section{0 - BIBLOGRAPHY}

BC GOV. "Columbia River Treaty." Columbia River Treaty, 1473168504. https://engage.gov.bc.ca/columbiarivertreaty/.

---. "From Company to 'Instant' Towns: Building Resilient Local Government in B.C.'s Resource Communities," n.d. https://www2.gov.bc.ca/assets/gov/british-columbiansour-governments/local-governments/governancepowers/from_company_instant_towns_building_resilient_local_government_in_bc _resource_communities.pdf?bcgovtm=buffer.

Вгаdbury, John. "Instant Towns in British Columbia: 1964 to 1972." Simon Fraser University, 1977. https://summit.sfu.ca/item/2873.

"British Columbia Labour Market Outlook: 2019 Edition," 2019, 210.

Вrown, Chloe. "The Geography of Climate Change in a Rural Resource-Dependent Town: The Case of McBride, British Columbia." Simon Fraser University, 2012. http://summit.sfu.ca/item/12472.

Canadian Architects Declare Climate \& Biodiversity Emergency. "Canadian Architects Declare Climate \& Biodiversity Emergency." Accessed January 8, 2021. https://ca.architectsdeclare.com/.

Columbia Basin Trust. "Our Story." Columbia Basin Trust. Accessed March 24, 2021. https://ourtrust.org/about/our-story/.

Community Tourism Foundations. "Nakusp-and-Аггоw-Lakes-Tourism-Plan-May-2009.Pdf." $\begin{array}{lll}\text { Tourism } & \text { British } & 2009 .\end{array}$ https://nakuspareadevelopment.files.wordpress.com/2016/11/nakusp-and-аггоwlakes-tourism-plan-may-2009.pdf.

FP Innovations. "BIOPATHWAYS-II-Web.Pdf." Accessed September 23, 2020. http://www.fpac.ca/publications/BIOPATHWAYS\%20ll\%20web.pdf.

Government of Canada, Statistics Canada. "Census Profile, 2016 Census - Nakusp, Village [Census Subdivision], British Columbia and British Columbia [Province]," February 8, 2017. https://www12.statcan.gc.ca/census-recensement/2016/dppd/prof/details/page_Figures.cfm?Lang=E\&Tab=1\&Geo1=CSD\&Code1=5903050\&Geo2= $P R \&$ Code2 $=59 \&$ SearchText=Nakusp\&SearchType $=$ Begins \&SearchPR $=01 \& B 1=A l l \& T A B I D$ $=1 \&$ type $=0$.

---. "The Great U.S. Recession and Canadian Forest Products," July 10, 2013. https://www150.statcan.gc.ca/n1/pub/11-626-x/11-626-x2013028-eng.htm.

Halseth, Greg, and Lana Sullivan. "From Kitimat to Tumbler Ridge: A Crucial Lesson Not Learned in Resource-Town Planning." Western Geography 13/14 (n.d.): 132-60.

Halseth, Greg, Lana Sullivan, and Laura Ryser. "Service Provision as Part of Resource Town Transition Planning:", n.d., 33. 
Meissner, Dirk. "Worse than 2008? B.C. Forest Industry Facing Unprecedented Struggle." CTVNews, January 19, 2020. https://www.ctvnews.ca/business/worse-than-2008-bc-forest-industry-facing-unprecedented-struggle-1.4774063.

Molander, Mariko Gwendolyn. "Decolonizing the Mind: Centring Settler-Colonial Disposession and Mutually Contested Sovereignties in British Columbia's Forestry Landscape and Naгrative." University of British Columbia, 2014. https://doi.org/10.14288/1.0167634. Nakusp, Investment Ready. "Nakusp Is READY FOR INVESTMENT." Investment Ready Nakusp. Accessed January 11, 2021. https://investmentreadynakusp.ca/.

Nesteroff, Greg. "Nakusp from a Sinixt Word, but Meaning in Doubt." Arrow Lakes News, June 1, 2016. https://www.arrowlakesnews.com/news/nakusp-from-a-sinixt-wordbut-meaning-in-doubt/.

Pheidias Project Management Corp. "Jumbo Glacier Resorts Proposal." Accessed December 22, 2020. https://www2.gov.bc.ca/assets/gov/farming-natural-resources-andindustry/natural-resource-use/all-seasons-resorts/jumbo/jgr-mp_2010.pdf.

Pressman, Norman E. P., and Kathleen Lauder. "Resource Towns as New Towns." Urban History Review, no. 1-78 (1978): 78. https://doi.org/10.7202/1019441аг.

Pryce, Paula. Keeping the Lakes' Way. Accessed March 11, 2021. https://booksscholarsportal-

info.proxy.libгагу.carleton.ca/en/read?id=/ebooks/ebooks0/gibson_crkn/2009-1201/6/417956.

Ryser, Laura, Sean Markey, Greg Halseth, and Kristina Welch. "Moving from Mobility to Immobility in the Political Economy of Resource-Dependent Regions." Applied Mobilities 4, no. 3 (September 2, 2019): 307-28. https://doi.org/10.1080/23800127.2017.1421290.

Sandford, Robert William, Deborah Harford, and Jon O'Riordan. The Columbia River Treaty: A Primer. Victoria, CANADA: RMB Rocky Mountain Books, 2014. http://ebookcentral.proquest.com/lib/oculcarletonebooks/detail.action?docID=5107146.

Schlossberg, Магс, Roger Lindgren, Dave Amos, and John Rowell. "Rethinking Streets for Bikes An Evidence-Based Guide to 25 Focused Street Transformations." University of Oregon, 2019. https://nitc.trec.pdx.edu/research/project/1081/From_Knowledge_to_Practice:_Ret hinking_Streets_for_People_on_Bikes.

"Termination of the Jumbo Glacier Resort Рroject." Accessed December 22, 2020. http://jumboglacierгesort.com/termination-of-the-jumbo-glacier-геsort-project/.

Village of Nakusp. "2021-Offical-Community-Plan-Reduced.Pdf," February 2021. http://nakusp.com/wp-content/uploads/2021/03/Schedule-A-Offical-CommunityPlan-Reduced.pdf. 
---. "Economic_summit_final_report_november_2011.Pdf." Accessed October 8, 2020. https://nakuspareadevelopment.files.wordpress.com/2016/11/economic_summit_final _report_november_2011.pdf.

---. "Nakusp-Zoning-Map-Sept-2019.Pdf." Accessed October 8, 2020. http://nakusp.com/wp-content/uploads/2020/09/Nakusp-Zoning-Map-Sept2019.pdf.

---. "Zoning BYLAW-614-Consolidated-to-Jan-15-2019-614-24.Pdf." Accessed October 8, 2020. http://nakusp.com/wp-content/uploads/2019/02/BYLAW-614-Consolidatedto-Jan-15-2019-614-24.pdf.

"Wood First Act." Accessed January 2021. https://www.bclaws.gov.bc.ca/civix/document/id/complete/statreg/00_09018_01. 